\author{
Bura László
}

\title{
A Szatmári \\ Református Kollégium és diákjai \\ (1610-1852)
}

Az Erdélyi Múzeum-Egyesület kiadása

Kolozsvár 1994

Sorozatszerkesztő: Dávid Gyula

ISBN: 973-96946-0-8 


\section{TARTALOM}

\section{Iskolatörténeti vázlat}

1. Szatmár feudalizmus korabeli politikai-közigazgatási helyzete

2. A szatmári iskolázás kezdetei

3. A gimnázium (kollégium) szerkezete és müködése 1610-től 1754-ig

4. A kétosztályú grammatikai iskola korszaka és a gimnáziumi tagozat újraéledése (1754-1852)

5. Kitekintés: az abszolutizmus korától az iskola megszüntéig

II. Az iskola belső élete

1. Az iskola vezetése

2. Tantervek, tananyag

3. Az iskola könyvtára, a könyvtárjegyzék oktatástörténeti értékelése

4. Az iskola törvénykönyve

\section{A kollégium diáksága}

1. A források

2. A diáklétszám alakulása

3. A diákok származáshelye

4. A diákok továbbtanulása, pályaválasztása

5. A diákság társadalmi összetétele

6. A diákság létszáma, származási helye és társadalmi összetétele az abszolutizmus korától a második világháború végéig

\section{Utószó}




\section{Iskolatörténeti vázlat}

\section{Szatmár feudalizmus korabeli politikai-közigazgatási helyzete}

Művelődéstörténetünk sürgető feladata legrégibb középiskoláink történetének, illetőleg társadalmi szerepének eddig ismert kerettörténetüket meghaladó bemutatása. ${ }^{1}$ Szatmáron a XVI. században két gimnázium létesült, a szatmári református kollégium, amely 1610-ben a már régen müködő latin iskolából alakult gimnáziummá, és a Pázmány Péter által alapított, az 1630-as évek végén grammatikai tagozatként müködő szatmári jezsuita kisgimnázium.

Munkánkban a szatmári református kollégium korszerü szempontú vizsgálatára törekszünk. Helyének kijelölése a magyar iskolázás múltjában megkívánja, hogy utaljunk a város feudalizmus kori politikai és közigazgatási viszonyaira, valamint az iskola elötörténetére.

Az alföld északkeleti szélén és a tőle keletre húzódó dombos vidéken már a XI. század folyamán kialakult a Szatmár váráról elnevezett, előbb királyi, majd később nemesi vármegye. Központja a Szamos mellé épített királyi vár, amely a vidéken átvezető fontos kereskedelmi utakat is ellenőrizte. A későbbi századokban földrajzi helyzeténél fogva katonai és politikai jelentősége is megnövekedett, minthogy erre a vidékre a Habsburg-királyság és az erdélyi fejedelemség egyaránt igényt tartott. Bár átmenetileg többször is gazdát cserélt a hatalmi harc során, Szatmár 1540-től a XVII. század második feléig többnyire Erdélyhez, azután a királysághoz tartozott.

Ezek a politikai és társadalmi viszonyok számottevően befolyásolták a szatmári iskolázás kezdeteit, a XVI. század derekától pedig a református iskola, később kollégium diákságának összetételét, nemcsak a diákok társadalmi eredetét, hanem származási helyét illetően is. A politikai és társadalmi viszonyok eredményeként e kor sajátos jelensége ugyanis a diákvándorlás, ami abban nyilvánult meg, hogy a Habsburg-uralom elől vagy a törökök által megszállt területekről - politikai vagy vallási okokból - sok vállalkozó szellemü diák iratkozott be szülőföldjétől igen távoli iskolákba. Gazdasági okok, vallási küzdelmek vagy a magyar nyelv tanulásának igénye számos erdélyi, székelyföldi vagy szászföldi diákot is távolabbi iskolák választására késztetett.

\section{A szatmári iskolázás kezdetei}

Szatmár és Németi XVI. század előtti iskoláira csupán kevés adatból s az ezekre vonatkoztatható analógiák alapján következtethetünk.

Iskola kezdeményezésére Szatmáron I. (Szent) István királynak ama rendelkezése alapján gondolhatunk, amely elöírta, hogy a városi plébániák mellett iskola is létesüljön. Ilyen létesülhetett tehát a vár területén épült templom mellett. ${ }^{2}$ Még valószerübbnek vélhetjük iskola létesülését a XI. század elején bajor telepesekből alakult városkában, Németiben. ${ }^{3}$

\footnotetext{
${ }^{1}$ A korszerü iskolatörténet feladatait Jakó Zsigmond körvonalazta A Bethlen Kollégium diáktársadalma a feudalizmus korában címü tanulmányában. = Jakó Zsigmond - Juhász István: Nagyenyedi diákok 1662-1848. Kriterion Könyvkiadó, Bukarest 1979. 41-80.

${ }^{2}$ A szatmári püspöki egyházmegye Emlékkönyve fennállásának századik esztendejében (Schematismus centenarius) 1804-1904. Szatmár 1904. 118-120.

${ }^{3}$ Györffy György: István király és müve. Gondolat, Budapest 1977. 512.
} 
Analógiák alapján okunk van arra, hogy föltételezzük: a XIII. század elejétől plébános vezette iskola müködött - talán folyamatosan - Németiben is, Szatmáron is, ugyanis az ismert plébánosok közül többen oktatói-tanítói tevékenységük alapján magister, magyarul mester címet viseltek. $^{4}$

A szatmári plébánia a XIII. század elejétől főesperesi vezetésü, kiváltságos - az esztergomi érseknek közvetlenül alárendelt - intézmény ${ }^{5}$, amelynek vezetöi - amint ezt Szatmárnémeti 1230. évi kiváltságlevele ${ }^{6}$ is kiemeli - a föesperesi hatáskörnek megfelelő felkészültségűek és hozzáértésűek kellett hogy legyenek.

Bizonyos, hogy a főesperesek közt már a XIII. század elején s majd a XV. század folyamán többször is voltak külföldi egyetemet végzettek, ${ }^{7} \mathrm{~s}$ talán az iskolák élére is került akademita. A ferencesek és a domonkosok szatmári, illetőleg németi rendháza is fontos bázisa lehetett egy (vagy akár több?) középkori skólának. Valószínűleg a domonkos szerzetesek iskolája volt az, amelyről a (későbbi) források azt írják, hogy tekintélyes, rendezett, latin iskolaként müködött. ${ }^{8}$

Az intézményröl azonban részleteket (néhány tanára s tanulója nevén kívül) ${ }^{9}$ nem ismerünk. A domonkos szerzetesház (s valószínüleg az iskola is) 1560-ban még megvolt, 1570-ben szünt meg. ${ }^{10}$

Hasonlóképp nincsenek ismereteink az 1535 utáni években kialakított első protestánshumanista iskoláról sem. Az első konkrét adatunk 1610-ből való, amikor is a január 1-jén keltezett jegyzőkönyv szerint „a becsületes tanács úgy rendelte, hogy amikor alkalmatosság adatik, wittembergus scholamestert [fogadjanak], amikor pedig abban fogyatkozás lenne, honhazánkban tanult deákot". ${ }^{11}$ Ez azt jelenti, hogy külföldi egyetemen végzett rektort kívántak hívni (a wittembergus erre utal), de nem zárták ki a domidoctus „deák” alkalmazását sem.

A szatmári városi-humanista iskola - amely a források szintjén igazolhatóan 1594-ben biztosan müködött ${ }^{12}$ - magasabb szintre emelkedése Milotai Nyilas István szatmári református lelkész (1607-1618) közreműködésének eredménye. Példaképe a debreceni iskola

${ }^{4}$ Szirmay Antal: Szatmár vármegye fekvése, története és polgári esmérete. Buda, 1800. I. 39-40.

${ }^{5}$ Catalogus Clerii Szathmariensis, 1827.2.; Tonk Sándor: Erdélyiek egyetemjárása a középkorban. Kriterion Könyvkiadó, Bukarest 1979. 136-137.

${ }^{6}$ Kovács István: A szatmári ref. iskola története. Debrecen 1880. 3.

${ }^{7}$ Tonk: i.m. 136-137.

${ }^{8}$ Bagossy Bertalan és munkatársai: Szatmár-Németi sz. kir. város. = Szatmár vármegye monográfiája. Magyarország vármegyéi és városai. Országos Monográfia Társaság kiadása. Budapest, é.n. [1907]. 167-168.

${ }^{9}$ Az iskolában tanított Thomas de Zothmar (1340); Martinus Horváth, Bakócz Tamás és testvére tanára: Petrus Bachkay tanári beiktatása 1554-ben történt.

Bura László: Épület és intézmény. Szatmári Friss Újság 1993. július 3., és uő. A szatmári katolikus gimnázium. Kézirat.

${ }^{10}$ Szirmay: i.m. I. 207.

${ }^{11}$ Bakcsy Gergely: A szatmárnémeti ev. ref. fögimnázium története. Szatmár 1896. 8.

${ }^{12}$ Bakcsy: i.m. 5. 
(amelynek 1599-ben szeniora, 1603-ban tanára), ezért mindenekelőtt alkalmas helyett keres a tervezett gimnázium számára. A városi tanáccsal eladatja a régi paplak melletti iskola helyiségét és megvéteti a (mai) telket.

Egy jóval későbbi, a szatmári református egyház levéltárában található okmány expressis verbis úgy utal 1610-re, mint a kollégiumi típusú „,középfokú” iskolává emelkedés évére: „Schola Sathmariana ab immemoriali tempore suos habuit rectores et studiosos togatus plus minus 10. Anno 1610 Schola haec in celebrem gyimnazii formam mutata est."13 (A XVII. századi latin szövegekben ezt a magasabb szintü iskolatípust még a hagyományos schola vagy gymnazium elnevezéssel illették. A kollégium szó a XVIII. században jelenik meg szövegekben a kiemelkedő protestáns iskolákra.)

A XVI. század második felében müködő szatmári iskola szerepe a protestáns vezető réteg nevelése volt, részben nemes családok gyermekeiből, részben a városi polgárság felsőbb rétegeiböl.

\section{A gimnázium (kollégium) szerkezete és múködése 1610-től 1754-ig}

A kollégium típusú iskola szorosan kapcsolódott a korábbi külföldi és hazai előzményekhez, magába sürítette a humanizmus hatásait, s olyan müveltséget nyújtott, amelynek alapvető tartalma a latin nyelv és a klasszikus szerzők müveinek beható ismerete volt. Ha a kollégiumnak akadémiai tagozata is volt, az említett müveltségre épült a hagyományos tartalmú arisztotelészi filozófia és a skolasztikus teológia. ${ }^{14}$ A szatmári református iskola a kollégium gimnáziumi részlegét építette ki, amelynek ekkor három tagozata volt: elemi ismeretek; latin grammatika; poétika-retorika.

A harmadik tagozaton klasszikus prózaírók és költők müveinek irodalmi szempontú tanulmányozása folyt, ezzel párhuzamosan természetesen részletes elméleti poétika- és retorikaoktatás is.

Az iskola tanítóiról a XVI. század végéig nincs adatunk. A századfordulón - 1597-1605 között - Szegedi Lörinc debreceni kollégiumi tanító lett az iskola rektora. ${ }^{15}$ Ezt követően

${ }^{13}$ Kovács: i.m. 5. és Bakcsy: i.m. 6, 8.

${ }^{14}$ Mészáros István: Az iskolaügy története Magyarországon 996-1777 között. Budapest 1981. 240.

15 Herepei János: XVI-XVII. századbeli papok, mesterek, diákok a Szatmári Református Egyházmegyéböl. Egyháztörténet, 1943. 29. Debrecenben egyébként Szegedi Lőrincröl úgy tudták, hogy elesett az 1596-i mezőkeresztesi csatában, s ezt az aláíási jegyzőkönyvbe neve mellé be is jegyezték. Vö. Nagy Sándor: A debreceni kollégium mint egységes intézmény az egyetem kialakulásáig. [Debrecen] 1940. 32.

Ugyancsak Herepei idézett tanulmányának 30. lapján az 1610. évtől megemlíti Gönczi András tanító nevét, aki ekkor a várbeli iskolában müködött. Neve egyébként az Erotemata Gvardini per Georgium Rithaymer pro rei necesitate aucta címü könyv bejegyzésében maradt fenn. A könyv jelenleg a volt kolozsvári református kollégium könyvtárában található, száma 95990. A bejegyzés utolsó mondata: „Ipsequidem Andr[eas] Geonczi Ludimagister Arcis Zatthmarien[sis] dono dabat Discipulo suo chariss[im]o Pet[ro] B. Zatthmari Anno 1610."

Az adat egyébként megdönti Bartók Gábornak azt az állítását, hogy a várbeli iskolát Bethlen Gábor létesítette volna a várkatonák gyermekeinek oktatására, akkor, amikor 1622-ben birtokába vette a várat. (Vö. Bartók Gábor: Szatmár-Németi szabad királyi város egyházi és polgári történetei. Szatmár 1860. 115. és uő.: A szathmári és németi ref. egyházak és iskolák története. Sárospataki Füzetek, 1880. 306. 
1610-ig ismét nincs adatunk, 1610-től viszont az iskola anyakönyve megőrizte a tanárok nevét. Az iskola vezetője most már nem rektor, hanem professzor címet visel.

A szatmári iskola jórészt a debreceni kollégiumtól kapta a tanítóit, később tanárait, felépítésében, tananyagában is azt követte, feltételezhető tehát, hogy osztályszerkezete, illetőleg a tanulmányi évek megnevezése a XVII. század eleji szatmári iskolában a debrecenivel megegyező volt. A XVI. században a hatosztályú középiskola felé haladó debreceni iskola alsó- és középfokú osztályai a következöképp alakultak:

Az osztály neve: ${ }^{16}$ Számozással:

\begin{tabular}{rll}
\hline I. & abc-darius & sextarius \\
II. & donatista & quintarius \\
III. & etymologicus & quartarius \\
IV. & syntaxista & tertiarius \\
V. & poetika & secundarius \\
VI. & retorika & primarius
\end{tabular}

A XVI. századi szatmári iskolában azonban a tanulókat még bizonyosan nem osztották be tanulmányi éveik szerint külön osztályokba, s ez az állapot folytatódhatott a XVII. század első felében is. Akárcsak az egykorú kollégiumokban, Szatmáron is minden bizonnyal elmosódott a határ az elemi iskola osztályai és a középiskola alsó osztályai között, s a középiskola osztálykeretei sem különültek el mereven egymástól. ${ }^{17}$ Ezt igazolja Szatmári Miklós tanár 1652. évi felterjesztése is, amelyben előadja, hogy a szatmári iskolát classisokra (osztályokra) szeretnék osztani a váradi (fejérvári) és bányai iskolák mintájára. Ehhez a reformhoz a megye pénzbeli támogatását kéri, négy oktató számára fizetést. Minthogy a tanács nem nyújtott segítséget a fejlesztéshez, a szülők inkább a katolikusok iskolájába vitték gyermekeiket, s ezek maguk is oda kívánkoztak. ${ }^{18}$

A szatmári iskolában 1610-től kezdve a kollégium tanára nem egyedül, hanem a legidősebb diákok közül választott segítőtársak, az ún. collaborátor-ok ${ }^{19}$ segítségével oktatott. A XVIII. századi anyakönyv bejegyzései szerint már 1610-ben két segédtanító (collaborátor és collaborátor secundus, azaz második segédtanító) müködött a kollégiumban, a következő években néha három is.

A korabeli latin nyelvhasználat nem volt egyértelmü, minden körülmények között azonos jelentésü, így elképzelhető, hogy az 1643-as aláírási jegyzőkönyvben olvasható collaborátor primus, collaborátor secundus, collaborátor tertius az első, a második, a harmadik tanítót jelöli, de jelölheti a primarius, secundarius, tertiarius számozással jelölt osztály tanítóját is,

${ }^{16}$ Az osztályokat a korabeli leírások felülről lefelé haladó sorban, tehát a legnagyobbaktól kezdve sorolják fel; mi viszont a ma megszokott sorrendben, az alsóbb osztályoktól kiindulva.

${ }^{17}$ Rúzsás Sándor - Trócsányi Zsolt - Bodolay Géza - Kiss József - Pölöskei Ferenc: A pápai kollégium története. Budapest 1981. 17.

18 A vármegyei jegyzőkönyvekre hivatkozik (1652. év, folio 335.). Szatmár vármegye. Bp. [1907] Magyarország vármegyéi és városai. Szerk. Borovszky Samu. 445, 526.

${ }^{19}$ A collaborator a XVI. században általában a rektor melletti felnőtt tanár neve. Vö. Mészáros: i.m. 254., a református kollégiumokban később így hívják a rektor nagydiákok közül választott segítőtársait, segédtanítóit, akik a kisebb tanulókkal foglalkoztak a gimnaziális képzésben. Vezetőjük az első collaborátor. Vö. Mészáros: i.m. 314. 
ugyanis az anyakönyvekben egyaránt megtalálható a collaborator primarius (1654) és a collaborator primus (1660) megnevezés. A hatvanas évektől a tanító neve már praeceptor ${ }^{20}$ (köztanító, osztálytanító). Az 1660-as jegyzőkönyvben a praeceptor tertius megjelölést találjuk, az 1665-ös jegyzőkönyvben pedig a praeceptor quartarius, praeceptor syntaxis, poesis és a praeceptor grammaticae megnevezést; mindez utóbbi feltételezésünket látszik igazolni.

A XVIII. század első évtizedeinek osztályrendszerét nem ismerjük. Az 1731. április 20-i iskolaszéki jegyzőkönyv nyolc, az 1738. november 20-i hét osztályt említ, 1752-ben viszont csak hat osztály neve fordul elő. ${ }^{21}$ Az említett osztályok nevét - összehasonlítva a debreceni latin iskola 1742 óta érvényes osztályrendszerével - az alábbiakban közöljük:

\begin{tabular}{llll}
1731 & 1738 & 1752 & Debrecen, 1742 \\
\hline Alphabetistae Donatistae & Lectores & Lectores & Comparatistae \\
\hline Minores Rudimentistae & Comparatistae & Comparatistae & Sextarii decliniste \\
Majores Rudimentistae & Conjugistae & Conjugistae quintarii & conjugiste \\
Grammatistae & Grammatistae & $\begin{array}{l}\text { Grammatistae } \\
\text { quartarii }\end{array}$ & grammatista \\
Syntaxistae & Syntaxistae & Syntaxistae tertiarii & syntaxista \\
Poetae & Poetae & Poetae secundarii & poeta \\
Oratores & Rhetores & Rhetores primarii & orátorok és logikusok
\end{tabular}

Adatainkból megállapíthatjuk, hogy a szatmári református kollégiumban az osztályok megnevezése még ekkor sem szilárdult meg véglegesen, de nem fejeződött be az osztályokra való elkülönülés sem. A harmincas évek elején az alsó tagozaton még két csoportot, alphabetistákat (betűzőket) és donatistákat (a Donatus-könyv tanulóit) ${ }^{23}$ említenek, a gimnáziumi tagozat első két osztályát egyaránt rudimentistáknak hívják, s elkülönülésüket csak a minores (kisebbek) és majores (nagyobbak) jelző jelöli. A harmincas évek vége felé aztán a kezdőket egységesen lektoroknak (olvasók) nevezik, s láthatóan ekkor szilárdul meg a hatosztályos gimnázium is.

Az osztályok megnevezése nem teljesen azonos a debreceni iskola osztályelnevezéseivel, de nyilvánvalóan látható, hogy a szatmári református gimnázium hatosztályszerüsége már a XVII. század második felében kiformálódott, a XVIII. század második negyedében pedig teljesen megszilárdult.

A Szatmáron müködő felsőbb fokú iskola mellett Németiben is müködött hasonló jellegü iskola, amelyről azonban csak nagyon szegényes ismereteink vannak. Tudjuk róla, hogy ez is a debreceni kollégium partikulája volt, ${ }^{24}$ de csak a grammatikai osztályokig kifejlödött ún. csonka gimnázium. Feltehetően kevés tanulója volt, ami érthető is, hiszen a szatmári gimnázium közvetlen szomszédja volt. Ez lehetett az oka annak, hogy a németi iskolát 1749ben egyesítették a szatmári kollégiummal.

\footnotetext{
${ }^{20}$ Nagy: i.m. 52.

${ }^{21}$ Vö. Matricula studiosorum. 96. és Bakcsy: i.m. 54.

${ }^{22}$ A comparatisták neve korábban Debrecenben is alphabetisták (betűzők) és lektorok (olvasók). Vö. Mészáros 1981. 616.

${ }^{23}$ Donatus könyvének tanítása magyarul folyt. Mészáros: i.m. 138-144.

${ }^{24}$ Nagy: i.m. 65-66.
} 
Az 1660-as években a Habsburg-birodalom és a török nagyhatalom Erdély miatti hadakozásai Szatmárt is érzékenyen érintették, ugyanis a király zsoldos csapatai megszállták a várát, $\mathrm{s}$ az egész megyét szabadon rabolható területnek tekintették. A zsoldosok egyaránt sanyargatták a parasztságot és a nemességet, s így érthető, hogy a megyei közgyülés már 1664-ben határozatot fogad el a nemesség és a parasztság felfegyverkezéséről, a lakosságot sanyargató zsoldosokkal való fegyveres szembeszállásról.

A szatmári kollégium diákjait is érzékenyen érintették a zsoldosok rablásai-harácsolásai, hiszen sokuknak a családja szenvedett tölük, másrészt az idegen elnyomók elleni küzdelemre ösztönözhette őket a kollégiumban kapott nevelés is. Ezt igazolja a kollégium diákjainak a részvétele a batizvasvári ütközetben. Itt zajlott le ugyanis a korai kuruc kor első csatája.

A Wesselényi Ferenc nádor szervezte összeesküvés leleplezése után a bebörtönzés elöl megmenekültek 1672-ben Teleki Mihály erdélyi kancellárt választották fővezérükké. Teleki Mihály a Szamoshát erdeiben meghúzódó szegénylegényekből - a nép kurucoknak ${ }^{25}$ hívta öket - sereget toborzott, s első hadi vállalkozásként 1672 szeptemberében Szatmár elfoglalására készült. Seregéhez diákok is csatlakoztak, köztük a szatmári református kollégium 49 diákja. $^{26}$

\section{A kétosztályú grammatikai iskola korszaka és a gimnáziumi tagozat újraéledése (1754-1852)}

Az iskola történetében törést jelentett az 1754-es év, ugyanis a Helytartótanács az ellenreformáció szellemében az iskolát lefokozta és kétosztályú grammatikai iskolává minősítette. A tantestület azonban ebbe az állapotba nem nyugodott bele, $\mathrm{s}$ az iskola magasabb osztályait lassan ismét kifejlesztette. Nincsenek adataink az 1754 és 1788 közti időszakról, tudjuk viszont azt, hogy 1788-ban a gimnáziumban négy osztály müködött:

\footnotetext{
${ }^{25}$ Bagossy: i.m. 8.
}

${ }^{26}$ Ferenczy János közlése szerint (Művei V. 57-59.) a batizi temetőben található, a XX. század elején feltárt tömegsírban a sok száz halott között 73 diák (ifjú) is nyugszik, köztük a szatmári református kollégiumnak mind a 49 ott elesett diákja. Felsorolja a nevüket is: Szatmári István, Dányádi György, Biltzki János, Bikinyi Mihály, Poroszlai István, Baksai Mihály, Szenczi János, Tatai Sámuel, Nádudvari György, Szőlőskei István, Szalacsi János, Selyebi Mihály, Asrihai András, Diószegi Ferenc, Tunyogi Miklós, Belényesi János, Ladányi István, Csengeri András, Gacsályi Ferenc, Ecsedi János, Pákai Benedek, Maróthi István, Miskolczi István, Vecsei István, Borsvai Ferenc, Nagyari Ferenc, Dombi Ferenc, Gyarmathi Mihály, Czeglédi Oláh István, Kállai Mihály, Szőllősi Ferenc, Gyügyei Ferenc, Ujlaky István, Csengeri Mihály, Turi Sámuel, Tarpai András, Vári Miklós, Beregi Ferenc, Patóházi Pál, Miszti István, Szeremi István, Misztótfalusi Bálint, Szőlőskei János, Pályi György, Debreczeni János.

Forrásait nem ismerjük, viszont adatairól megállapítjuk, hogy nem hitelesek, ugyanis a Matricula studiosorumban csak az 1671-ben aláírt Stephanus Szőlőskei neve mellett olvasható: „25. Nov. Venit Sonkadinum ad rectoratum. Decollatus Batizini 20. Sept. anni 1672 a Germanis hujus loci, cum multis aliis studiosis." A Ferenczy névsorában több név feltehetően hibás olvasat vagy elírás, ugyanis Nagyari Ferenc és Asrihai András a jegyzőkönyvben Franciscus Nagyari és Andreas Aszchai, a közlésében olvasható Biltzki János az 1671-ben aláírt Johannes Bélteki lehetne. Bikinyi Mihály esetében a Bökényi családnévre gondolhatnánk, viszont ilyen nevü diák a kollégium anyakönyvében az adott időpont előtti tíz évben sem szerepel. Névsora azért sem hiteles, mert a felsorolt 49 név közül 25 diák neve szerepel az aláirási anyakönyvben a következő évben. Mindössze 24 tanuló neve nem fordul elő többé, ezek valóban meghalhattak a batizvasvári csatában. 
declinista, conjugista, grammatista és syntaxista. A gimnáziumi osztályok hivatalosan a lefokozott grammatikai iskola osztálykereteiben müködtek, osztatlanul, egyetlen tanító vezette őket. Ugyanekkor az elemi iskola háromosztályos volt: lektorok, collektorok és elementáriusok. ${ }^{27} \mathrm{Az}$ elemi osztályok tanulóinak nagyon nagy száma két tanító alkalmazását tette szükségessé.

Az iskola alsó tagozatán ekkor már mind általánosabb lehetett a magyar nyelvü oktatás, aminek bizonysága éppen a szatmárnémeti iskolarektor magyar nyelven írt tankönyve. Szatmárnémeti Pap István 1756-ban maga nyomtatta ki Magyarország versekben való rövid leírása címü, Nagykárolyban 1760-ban második kiadásban is megjelent könyvét, „,mellyet az oskolákban tanuló nevendékeny ifjatskák taníttatásokra Sz. Németi Pap István rendben szedett". ${ }^{28}$

A poétika és retorika osztály 1797-től indult újra, tanítóját, Laki Sándort - a hagyományokhoz híven - ezután professzornak nevezik, ő látja el az iskola igazgatói tisztét is. Két tanítót azonban az iskola csak a hivatalos állapot kijátszásával müködtethetett. Úgy oldották ezt meg, hogy a poétikai és retorikai osztály tanítóját az egyháztanács második papnak választotta. Így tanítói fizetését papbér címen a hívektől kapta.

Az iskola kényszerü helyzetét az osztályok elnevezése is tükrözte. Az 1820-1852 közötti időszak anyakönyvi bejegyzései tanúsítják, hogy a gimnázium alsó tagozatán még ekkor is az első esztendős grammatista, második esztendős grammatista, novitius syntaxista, veteranus syntaxista megnevezéssel jelölték a tanulók tanulmányi évét, csakis így működtethettek négy osztályt a hivatalosan kétosztályúnak engedélyezett iskolában.

Ezt a XVIII. század utolsó évtizedeiben kialakult formát a kollégium újraindult felső tagozatán is bevezették. A poétika és a retorika osztály sem különült el évfolyamokra.

A református iskolákra - akárcsak a szatmári gimnáziumra sem - nem hatott az állami nevelésügy 1777-ben kiadott Ratio Educationis néven ismert szabályzata, sem a magyar közoktatásügy átfogó rendszerét és tartalmát szabályozó, 1806-ban nyomtatásban is megjelent II. Ratio Educationis, ${ }^{29}$ ugyanis a protestánsok vallásszabadságát garantáló törvény biztosította teljes tanügyi önkormányzatukat, s így joguk volt a tanítás és tanulás módjának, szabályainak és rendjének saját elképzeléseik szerinti megállapítására, mindaddig, amíg a törvényhozás nem intézkedik a tanügy országos rendezéséről.

A protestánsok a törvényben biztosított tanügyi önkormányzatukra hivatkozva a két állami szabályzatot nem tartották magukra nézve kötelezőnek, s az oktatás és nevelés elméletigyakorlati kérdéseinek átfogó rendelkezésekkel, részleteiben, aprólékosan történő rögzítését szükségtelennek látták. ${ }^{30}$

A tiszántúli református egyházkerület egységesítő törekvésű nevelési-oktatási szabályzatát Budai Ézsaiás debreceni tanár állította össze. Az 1807-ben elfogadott Ratio Institutionis a latin iskolát továbbra is két részre osztja: a négyosztályos grammatikai és az utána következő háromosztályos „humán” tagozatra.

\footnotetext{
${ }^{27}$ Bakcsy: i.m. 25 .

${ }^{28}$ Mészáros: i.m. 607-608.

${ }^{29}$ Mészáros István: A magyar nevelés története. 1790-1849. Budapest 1968. 12.

${ }^{30}$ Mészáros: i.m. 62.
} 
Ezt követte a szatmári református gimnázium is, amelyben a poétikai és a retorikai osztályt három tanulmányi év alatt végezték. Ezt az osztályszerkezetet Szatmáron megőrizték 1821 után is, holott ekkor a debreceni szabályzatot módosították, s a humán osztályok számát kettőre csökkentették, ahogy ezt az állami szabályzat elrendelte. ${ }^{31}$

A szatmári gimnáziumban a felső osztályok, illetőleg a tanulmányi csoportok megnevezése a húszas évek elején még ingadozó, veteranus orátorok, poéták, novitius orátorok (1820), (veteránus) poéták, mediocrisok, novitiusok (1821). Az 1824/25-ös tanévtöl a poéta és orátor megnevezést együttesen használják: veteránus poéták és orátorok, mediocris poéták és orátorok, novitziusok, viszont a következő tanévtől már a harmadik esztendős, második esztendős, első esztendős rétorok és poéták megnevezés állandósul.

A kollégium tantestülete az 1820-as évektől három tanerős, egyikük tanítja a kétéves grammatista, másikuk a kétéves syntaxista, a professzor pedig a hároméves poétikai-retorikai osztályt.

Az 1820-tól vezetett anyakönyv a szatmári református kollégium alsó tagozatának osztályszerkezetében $\mathrm{s}$ feltehetően a tananyagban bekövetkezett változásokról is tanúskodik. Az anyakönyv szerint ugyanis az addigi középiskola négy alsó osztályának a novitius grammatista és a veteranus grammatista, a novitius és a veteranus syntaxista osztály felelt meg. Az anyakönyv ugyanakkor ezeket követően évröl évre közli a Nagyobb Magyar Fiú Oskola és a Kisebb Magyar Fiú Oskola tanulóinak a névsorát is.

A fentiekből következően a kollégium intézményének keretében két különböző elemi iskola müködött. Az egyik - a Nagyobb Magyar Fiú Oskola - a városi elemi iskolákra jellemző bővebb tananyaggal, a másik - a Kisebb Magyar Fiú Oskola - a falusi, ún. triviális elemi iskolának megfelelővel.

Az 1826/27-es tanév anyakönyvi bejegyzéséből aztán az derül ki, hogy a Nagyobb Magyar Fiú Oskola két osztályát tulajdonképpen declinista és conjugista osztálynak tekintik. A következő tanévtől viszont ugyanezeket az osztályokat az anyakönyv Nagyobb Nemzeti Oskola - azaz nemzeti nyelvű iskola -, a másik elemit pedig Kisebb Nemzeti Oskola néven említi. ${ }^{32}$

Az 1835/36-os tanévtől a Nagyobb Magyar Fiú Oskola az egyháztanács határozata értelmében ún. polgári iskolává alakult át.

A felsorolt tényekből arra kell következtetnünk, hogy a XIX. század első évtizedeiben valószínüleg, az 1820-as évektől bizonyosan szétválasztották a kollégiumi latin osztályokat az elemi oktatástól, amely magyar anyanyelvü volt. Másrészt pedig - feltehetően a jelentős számú városi polgárság igényeinek megfelelően - megteremtették az algimnázium első két osztályának megfelelő teljesen magyar nyelvü osztályt is. A grammatisták és a syntaxisták tehát továbbra is latinos tanulmányokat folytattak, a középiskola felsőbb osztályainak esetleges végzésére, míg a Nagyobb Magyar Fiú Oskola, illetőleg a polgári iskola tanulói anyanyelvükön polgári - iparos, kereskedö stb. - pályákra készültek.

\footnotetext{
${ }^{31}$ Mészáros: i.m. 96.

32 A Ratio Educationis nyomán a XVIII. század végén meghonosodott $\mathrm{s}$ a századforduló után is használatos „nemzeti iskola” kifejezés nemzeti - esetünkben magyar - nyelvű iskolát jelentett. Ezekben az olvasás, ének, írás tanítása magyarul folyt. Mészáros i.m. 17., és uő.: Népoktatásunk szervezeti-tartalmi alakulása 1777-1830 között. Budapest 1984. 29.; Bajkó Mátyás: Kollégiumi iskolakultúránk a felvilágosodás idején és a reformkorban. Akadémiai Kiadó. Budapest 1976. 64.
} 
1852-ben az abszolutizmus közoktatási reformjának, az Organisations Entwurfnak ${ }^{33}$ a rendelkezései értelmében vagy csak nyolcosztályos fö-, vagy négyosztályos algimnáziumot ismertek el, nyilvánossági jogot csak a szabályzatnak megfelelő, az engedélyezett tanterv szerint müködő iskola kaphatott. A rendelkezések szerint a nyolcosztályú gimnáziumban tizenkét, a négyosztályúban hat tanárnak kellett lennie, s mindegyiküknek 600-800 Forint fizetést kellett kapnia. A közoktatási reform ugyanekkor megkívánta az egységes állami tanterv alkalmazását, az állami iskolákban használatos tankönyvek bevezetését, a tanítóktól pedig tanári jogosítványt, bizonyítványt kért.

A gimnázium ezeknek a követelményeknek nem felelt meg, következésképp 1852 öszétől felső tagozatos osztályai már nem müködhettek, s algimnáziuma is elvesztette a nyilvános iskolai státust, csak magángimnáziumként müködhetett tovább, tehát államilag elismert bizonyítványt nem bocsáthatott ki. Ilyen magángimnáziumként müködött hét tanéven át, egészen 1859-ig.

\section{Kitekintés: az abszolutizmus korától az iskola megszüntéig}

Az Entwurf rendelkezései következtében elvesztett nyilvánossági jogot az iskola 1859-ben szerezte vissza: nyilvános algimnáziummá lett.

Természetesen azonnal feléledt az iskola teljes értékü középiskolává fejlesztésének óhaja és szándéka is, s ezért már a következő tanévekben (persze nem hivatalosan) megindították a gimnázium V. osztályát (1860/61-ben), majd a VI. osztályt (1861/62-ben). Az iskola nyolcosztályos teljes gimnáziumi rangját azonban csak 1890-ben ismerték el hivatalosan, ekkor megindult a VII., a következő tanévben pedig a VIII. osztálya.

Az 1890-es év jelentős állomása volt az iskola anyagi alapja fejlődésének is, az épület jelentős bővítését és második emeletének ráépítését ekkor fejezték be.

(Ismeretes, hogy Szatmáron az épületek a XVI-XVIII. században még vályogból és fából épültek; ilyen volt a régi iskola is, amely az egykori paplak mellett állott, de ilyen volt az iskola mai telkére a XVII. század elején emelt épület is. A ma is fennálló téglaépület építését 1805-ben kezdeményezték, s kivitelezése/felépítése másfél évtizedet igényelt. A hat osztály befogadására alkalmas egyemeletes épület - az akkori Rákóczi és Kazinczy utca sarkán 1822-ben készült el. Az épület Kazinczy utcai részét az 1880-as évek második felében nyújtották meg és az egészre ekkor még egy emeletet húztak.)

A nyolcosztályos fögimnáziummá válás az épület további bővítését igényelte, az egykori Rákóczi utcai (ma Piaţa Păcii) részt 1902-ben toldották az épülethez, amely így elnyerte végleges (ma is meglevő) formáját. A múzeumi hatóságok mủemléknek tekintik.

A szatmári református fögimnázium annak emlékére, hogy a mostani helyén 300 éve állt fenn (és vált - mai megnevezéssel - középiskolává), 1910. május 18-20-án jubiláris ünnepet rendezett. Az ünnepség egyik része a templomi ünnepély volt, amelyen - egyebek mellett - Bakcsy Gergely igazgató ismertette a főgimnázium 300 éves múltját és jelenét.

A jubileumi ünnepség keretében tanácskoztak az Országos Református Tanáregyesület tagjai; a tanáregyesület - tizennégy középiskola képviseltette magát - ekkor alakította meg az egyesület erdélyi körét és a tanítóképzö intézeti osztályt.

${ }^{33}$ Teljes nevén Entwurf der Organisation der Gymnasien und Realschulen. 
Az első világháborút követően a református fögimnázium léte ismét veszélybe került. A román polgári-földesúri kormány 1924-ben megvonta nyilvánossági jogát. A tanulóknak más iskolában kellett vizsgázniuk, igen magas vizsgadíjat kellett fizetniük. Mindezek a gimnázium fokozatos leépüléséhez vezettek: 1928-ban már csak háromosztályos algimnázium.

Újbóli kiépülése 1930-ban kezdődik, ekkor indul meg ismét a negyedik algimnáziumi osztály, a következő tanévtől pedig a felső tagozat. Így fokozatosan ismét nyolcosztályos gimnáziummá válik, 1935-ben: líceum.

Ez a fögimnáziumi korszak a második világháborút követő társadalmi változások folytán rövid idejü, 1948-ban ugyanis az iskolák államosítása megszünteti ezt a felekezeti gimnáziumot is.

A szatmárnémeti Református Főgimnáziumot ekkor az 1944 őszétől Állami Magyar Fiúlíceum néven müködött volt Királyi Katolikus Főgimnáziummal egyesítették, az új intézmény a református gimnázium épületében kezdte meg müködését Állami Magyar Líceum néven. (Ugyanez történt a két lánygimnáziummal.)

1948. szeptember 1-től tehát szétválik az épület és az intézmény. A gimnázium épületében müködő (még magyar tannyelvü) iskola nemsokára új nevet kap: 3-as számú Középiskola.

1957-ben újabb névváltoztatás következik: sikerül felvennie a Kölcsey Ferenc Líceum nevet. A névadás indoklására indítékot keres az akkori igazgató, s ez „az iskola fennállásának 400. évfordulója", amelyet számos rendezvénnyel megünnepelnek; helybeli román iskolák diákjaival többek között együtt koszorúzzák meg a batizi emlékmüvet is! (A szervezők nem ismerték az iskolatörténeti tényeket, $\mathrm{s}$ a városban alakult első protestáns [elemi] iskola [feltételezett] évéhez mérték az évfordulót.)

1958-ban azonban, az újabb tanügyi átszervezés során, a gimnázium koedukációs iskolává válik, ezúttal 2-es számú Elméleti Líceum néven (ekkor a Kölcsey egy része a lánylíceumba költözött, az alig egy éve felvett név elenyészett).

1961-ben - újabb átszervezés keretében - a gimnázium a Mihai Eminescu Líceummal egyesül (annak magyar tagozatává válik); a református gimnázium egykori épületében általános iskola marad. 1965-ben aztán ezt újra középiskolává fejlesztik 3-as számú Elméleti Líceum néven.

1971. szeptember 1. A városban müködő három líceum magyar tannyelvü osztályaiból minisztertanácsi határozattal magyar tannyelvü elméleti líceum alakul, a neve: Magyar Líceum. Az intézmény a „400 éves” iskola épületében kap helyet.

A romániai oktatásban bekövetkezett további változások azonban hamarosan érintik az iskolát, a változások jellegét az intézménynév változásai is jellemzik: 1976. aug. 31-től 1-es számú Reál-Humán Líceum (román és magyar tagozattal), 1977. aug. 1-től 5-ös számú Ipari Líceum.

Közben a líceum tíz párhuzamos osztályából a magyar tannyelvűek száma is fokozatosan csökkent, 1989-ben már csak három maradt.

Az 1989-et követő változások nyomán a líceum 1990 őszétől visszakérte és kapta nevét és jellegét. Ma Kölcsey Ferenc Elméleti Líceum, reál és humán profilú osztályokkal. (Az ipari osztályai az 1992/93-as tanév végére felszámolódtak; ismét magyar tannyelvü.) 
Az iskolatörténet tényeihez hozzátartozik, hogy 1991 szeptemberétől Szatmárnémetiben két (tulajdonképpen felekezeti érdekeltségü) új Líceum is indult: a Szatmárnémeti Református Teológiai Líceum és a Hám János Római Katolikus Szemináriumi Líceum. Ezek állami és egyházi alárendeltségủek, nem azonosak a hagyományos felekezeti iskolákkal.

A két intézmény közül egyik sem rendelkezik saját épülettel, diákjai délután tanulnak a Kölcsey Ferenc Elméleti Líceum épületében. 


\section{Az iskola belső élete}

\section{Az iskola vezetése}

Szatmár iskolája a reformáció utáni időszakban a városi tanács védnöksége alá került, a város vezetősége segítette, oltalmazta, föként miután a századforduló után megszületik a magasabb fokú, vagyis kollégiumi rangú iskola. Tanúsága ennek az, hogy 1608-ban az iskola számára telket vásárol, $\mathrm{s}$ fel is építteti a kollégiumot. A kollégium megindulásakor a városi tanács határozta meg a tanárok fizetését, a köztanítóknak járó díjakat, valamint a tanulók közösségét illető jövedelmi forrásokat. ${ }^{34}$

Másfél százados védnöksége alatt a tanács állapította meg a kollégium tanrendszerét, gondoskodott a tanári állások betöltéséről, meghatározta a tanárok és a diákok jogait és kötelességeit, s küldöttei révén részt vett a súlyosabb fegyelmi ügyek kivizsgálásában.

A kollégium ügyeit az iskolaszék vezette, amelynek állandó elnöke a kollégium professzora volt. Az iskolaszék tagja volt a diákság iskolagyülése által évenként (szavazattöbbséggel) megválasztott vezetőség, a senior (a diákközösség feje), helyettese, a contrascriba (a diákközösség ellenőre és az iskolaszék jegyzője), az egyes osztályok nagydiákok közül választott tanítói, a collaborátorok, illetőleg praeceptorok, valamint a XVIII. század elejétől rendszerint négy juratus (esküdt diák, szavazóbíró).

A tanulóifjúság önkormányzati szerve a coetus (gyülekezet) volt, ennek tagja volt minden tógás diák. Az egész évre megválasztott fentebb említett vezető tanács mellett ez még más diák-tisztségviselőket is megválasztott, némelyeket ugyancsak egész évre, másokat rövidebb időszakra.

Az 1610-1754 közötti időszak tisztségviselőinek teljes névsorát nem ismerjük. Az aláírási jegyzőkönyvek rendszerint jelölik a seniort, contrascribát, gyakran a collaborátorokat, illetőleg a praeceptorokat, juratusokat, s számos esetben a többi tisztségviselőt, a kántort, a szolgadiákok gondnokát, a gazdadiákot, sáfárt, a kémlelöt (explorator), a könyvtárost, az ételesdiákot (coquus).

Diák-tisztségviselőkről a Matricula studiosorumban megőrzött iskolaszéki jegyzőkönyvek egy része is tudósít. Több szól a senior és a contrascriba megválasztásáról, olykor lemondásáról. Némelyik jegyzőkönyv a könyvtáros, egy-egy juratus, néha praeceptor kijelöléséről tudósít, a szolgák felügyelőjének kijelöléséről is találunk említést. Teljes tanács megválasztásáról egyetlen, az 1731. április 20 -án készült jegyzőkönyv számol be. ${ }^{35}$

Az iskola vezető tanácsa felügyelt az intézeti rendre, és intézte a kollégium sokrétủ gazdasági ügyeit. Az iskolaszéki jegyzőkönyvek tanúsága szerint a kollégiumi tanács kezelte a kollégiumnak adott pénzbeli adományokat, számba vette a vidéki iskolák által a tanítónak

\footnotetext{
${ }^{34}$ Bakcsy: i.m. 8-10.

35 Harmaczi Gergely az orátorok, Tokai László a poéták, Tarczali János a syntaxisták, Kállai Ábrahám a grammatisták, Betsei György a nagyobb rudimentisták, Csengeri Pál a kisebb rudimentisták, Hidvégi István a donatisták, Sárközi Ferenc az alfabetisták praeceptora lett.
}

Ugyanekkor Harmaczi Gergelyt seniorrá, Csengeri Barhász Istvánt contrascribává választották. 
ment diákért fizetett díjakat. ${ }^{36}$ Az iskolaszék kezelte azt az alamizsnából származó közös jövedelmet is, amelyet a nyári szünetben, illetőleg az ünnepek alkalmával a környező falvakban a diákok prédikációval szereztek.

Az iskolaszék volt a kollégium fegyelmi bírósága. A hanyagokat elmarasztalta, nyilvánosan megrótta, olykor kisebb büntetést is rótt rájuk (soron kívüli kapusszolgálat stb.). A fegyelmi ügyeket az iskolaszék a hetente tartott gyülésein tárgyalta, a kihágások ügyében ítéletet hozott.

A közösség életét, munkarendjét, gazdasági ügyeit a vezető tanács - senior, contrascriba, collaborátorok - a többi megválasztott tisztségviselő segítségével irányította és ellenőrizte.

Ugyancsak fötisztviselö, tulajdonképpen a collaborátorral egyenrangú segédtanító volt a kántor - már 1612-től említik -, akinek feladata az iskolai énektanítás. Tisztségéhez tartozott a templomi és a temetési szertartáson részt vevő diákok énekének vezetése, így egy személyben a templom kántora is volt. ${ }^{37}$

A szolgadiákok gondnoka (curator, curator servilientum) felügyelt a kollégiumban tanuló szegénysorsú, magukat szolgai munkák elvégzése révén fenntartó diákokra. A debreceni kollégium gyakorlata szerint - a XVIII. század elejéig - nemcsak gondnoki teendőket látott el, hanem egyszersmind a keze alá adott gyermekek tanítója és nevelője is volt. ${ }^{38}$ Feltételezhető, hogy ugyanebben az időszakban a szatmári iskolában is hasonló gyakorlat élt.

Az oeconomus (gazdadiák, sáfár) feladata volt a rend közvetlen fenntartása. Terhes feladat volt, s ezért mindig csak magasabb évfolyamú tanuló viselte. Nem állapítható meg, hogy a

${ }^{36}$ A Matricula studiosorum 124-125. lapjának bejegyzései szerint a kollégiumtól kapott tanítókért az egyes egyházközségek a következő összegeket fizették:

\begin{tabular}{|c|c|c|c|}
\hline Időpont & A falu & A tanító neve & Forint, dénár \\
\hline \multirow[t]{5}{*}{ 1725. január } & Apa & Josephus Németi & 1,50 \\
\hline & Péterfalva & Valentinus Vári & 3,06 \\
\hline & Csenger & Michael Nyíregyházi & 3,06 \\
\hline & Milota & - & 0,27 \\
\hline & Gyarmat & Johannes Vári & 1,36 \\
\hline május 1. & Szaniszló & Samuel Török Szathmári & 3,06 \\
\hline \multirow[t]{5}{*}{ 1727. január 8 . } & Gyarmat & - & 1,50 \\
\hline & Németi & - & 0,60 \\
\hline & Géberjén & - & 0,43 \\
\hline & Matolcs & Nicolaus Rápolti & 3,00 \\
\hline & Cseke & Franciscus Szathmári & 1,53 \\
\hline \multirow[t]{4}{*}{ 1728. április 20.} & Gyéres & Nicolaus Czeglédi & 1,51 \\
\hline & Újváros & Josephus Lévai & 1,50 \\
\hline & Matolcs & Andreas Sz. Szathmari & 1,51 \\
\hline & Sz. Váralja & Martinus Varallyai & 1,51 \\
\hline október 9. & Szamosújlak & Samuel Göntzi & 1,52 \\
\hline október 20. & Homok & - & 0,45 \\
\hline
\end{tabular}

Valamennyi tanító 1724-ben a matricula jegyzőkönyvében diákként szerepelt, tehát a következő év(ek)ben kerülhetett a tanítói állásba.

${ }^{37}$ Mészáros 1981. 254, 324. és Nagy: i.m. 98.

${ }^{38}$ Nagy: i.m. 99. 
szatmári iskolában ez a megbízatás egész évre vagy csak rövidebb időszakokra szólt-e. ${ }^{39}$ Valószínüleg ő ügyelt fel a gyüjtésből és az adományokból szerzett természetbeni javakra.

Az explorátor, kémlelő hivatala az ünnepi kántálás intézményével kapcsolatos. Neki kellett megtudnia, hogy a városban van-e valamilyen ünnepélyes összejövetel - lakodalom, születésnapi ünnepség, disznótor stb. -, ahol az énekes gyermekeknek érdemes, sőt illő megjelenni. Nyomozása eredményét a seniornak vagy a contrascribának kellett jelentenie, aki azután utasította, hogy vezesse az énekes diákokat a „laktató énekmondás” helyeire. ${ }^{40}$

Az ételesdiák, a coquus az ételhordás rendjére felvigyázó nagydiák volt. A diákok egy részét a város polgárai „sorkoszttal” élelmezték, az ételt kisdiákok vagy szolgadiákok hordták be a kollégiumba. A kollégiumnak nagy valószínüséggel saját főzőháza is volt, ennek müködését a városi tanács által megajánlott javadalom biztosította, $s$ feltehetően itt fözettek azok számára is, akik nem szorultak rá a polgárok segélyére. A kollégiumi konyha ügyvitele szintén az ételesdiák feladata volt.

Az aláírási jegyzőkönyvben évenként több ételesdiák is szerepel, ami azt sejteti, hogy a tisztség csak rövidebb, meghatározott időszakra szólt. ${ }^{41}$

A könyvtáros a kollégium könyvtárát kezelte, nyilvántartotta a könyvkölcsönzéseket, a jurátusok a kollégiumi bíróság ülésein az iskolai törvények igazságos alkalmazását vigyázták.

1747-ben a városi tanács az eklézsia ügyeinek intézésére egyháztanácsot (consistorium) hozott létre, s hatáskörébe utalta az iskolákat és az oktatás ügyét. Ezután az egyháztanács - elnöke a lelkész, jegyzője a kollégium professzora - ellenőrizte a tananyagot, a könyveket $s$ a tanítási módszereket is. A szükségleteknek és a követelményeknek megfelelően határozott a tógátusok és a mendikánsok (szolgadiákok) számáról.

${ }^{39}$ A debreceni kollégiumban az ökonómus tisztségét hetente más-más tanuló látta el. Nagy: i.m. 100.

${ }^{40}$ Benkő Samu: Sorsformáló értelem. Mủvelődéstörténeti dolgozatok. Bukarest 1971. 141.

41 A debreceni kollégium 1657. évi törvénykönyve szerint (VIII. fejezet, 1-6. cikkely) egy-egy nagydiák két hónapig ellenőrizhette az ételhordás és a főzés rendjét. Nagy: i.m. 100. 


\section{Tantervek, tananyag}

A szatmári református kollégiumban a XVI. században és a XVII. század első felében tanító tanárok jelentős része tanulmányait a debreceni kollégiumban és a sárospataki kollégiumban végezte, többeket Erdélyből hívtak meg a professzori tisztségre. A közel másfél évszázad alatt itt müködő tanárok közül 31-en külföldi akadémiákon szerezték meg a legmagasabb képzést. $^{42}$

Az elmondottakból következik, hogy a debreceni és a sárospataki iskolából Szatmárra érkezett tanítók, tanárok az itteni iskolában is ugyanazt igyekeztek megvalósítani, amit ők diákkorukban maguk körül láttak. Érthető tehát, hogy a szatmári kollégium belső rendjében, tananyagában, tanulmányi szervezetében, egész szellemiségében a testvér kollégiumokkal azonosult.

A szatmári iskolának föként a debreceni kollégiummal alakult ki ily módon egy sajátos, kötetlen kapcsolata, melynek következtében a kollégiumot grammatikai iskolává való lefokozásáig a debreceni kollégium ún. partikulájának, résziskolájának tekintették. ${ }^{43}$

Az egyháztanács egy 1795-ben készült jegyzőkönyve azt igazolja, hogy az újból fejlődésnek induló gimnázium továbbra is a debreceni kollégiumhoz igazodik. A jegyzőkönyv ugyanis megállapítja, hogy a szatmári iskola egyes osztályaiban használt tantervek a debreceni kollégium azonos szintű osztályaiban alkalmazott tudományos tantervek alapján készültek. ${ }^{44}$ Így aztán, ha a szatmári kollégium tantervei nem is maradtak fenn, valamelyest körvonalazhatjuk az itt tanított tananyagot és az oktatási módszereket.

A XVII. század eleji református iskoláktól sem kívántak mást, mint hogy alapos és pontos latin nyelvtudást s ehhez kapcsolódó, vallásos motivációjú klasszikus-humanisztikus müveltséget adjanak. Ennek oka nevelésük-oktatásuk legfőbb céljában rejlett. A protestáns iskolaszervezők szerint ugyanis minden protestáns értelmiségi férfi - pap, tanár, orvos, tudós stb. - számára szükséges az alapos vallási képzettség. A különböző életpályákra igyekvő tanulók aztán választott életcéljuknak megfelelően elöbb vagy később abbahagyták a tanulmányokat, kimaradtak az iskolából. Aki viszont eljutott a protestáns kollégium legfelső, akadémiai tagozatáig, tulajdonképpen papi képzést-képesítést nyert.

Ez az állapot nem azt jelentette, hogy a történelmet, földrajzot nem tartották a müveltség fontos részének, csupán úgy vélték, hogy az iskola által nyújtott és elsajátított müveltség birtokában az ifjú és a felnőtt tökéletesen eligazodik a bőven rendelkezésre álló történelmi és földrajzi könyvek között, nem szükséges azt még külön „tanítani” is. Feleslegesnek ítélték az anyanyelvvel való oktatásszerü foglalkozást is, egyszerűen azért, mert úgy vélték, hogy anyanyelvét mindenki ismeri. ${ }^{45}$

A XVII. század negyvenes éveiben két alkalommal is megvitatták a teológiát célzó gimnaziális képzést adó református iskolák szervezetének, tananyagának, tankönyveinek a

\footnotetext{
${ }^{42}$ A Matricula studiosorum azokat a tanárokat, akik külföldi egyetemeken tanultak, clarissimusoknak nevezi. Nevük megállapítható a tanárok felsorolásából. Vö.: Bura László: Szatmári diákok 16101852. Fontes Rerum Scholasticarum V. Szeged 1994. 9-10.

${ }^{43}$ Nagy: i.m. 65-66.

${ }^{44}$ Bakcsy idézett mủvének 82. lapján utal a debreceni ev. ref. főgimnázium 1894-95. évi Értesítőjére, amely a Ratio Educationis előtti, alatti és közvetlen utána fennálló helyzetet mutatja be.

${ }^{45}$ Mészáros 1981. 252-253.
} 
kérdéseit. Az 1646-os szatmárnémeti, ${ }^{46}$ majd az 1748-as sárospataki zsinaton a fenti jellegü iskolák hagyományos rendjének további fenntartása mellett döntöttek. ${ }^{47}$

Bizonyosnak tekinthetjük, hogy a tanácskozások színhelyén - Szatmárnémetiben, Sárospatakon - az ott elfogadott módon és szellemben tanítottak. Mi lehetett a hagyományos rend? Valószínüleg az, amelyet a Sárospatakon 1621-ben készült törvénykönyv rögzített. ${ }^{48}$ Eszerint az iskola tanulóinak a latin nyelvtan, a logika, retorika, valamint a vallási ismeretek elsajátítására kellett törekedniük, ugyanakkor azonban az iskolában tanítottak fizikát, metafizikát, görög és héber nyelvet is, valamint görög-római klasszikusokat. ${ }^{49}$

A sárospataki mintájára készült 1657-es debreceni szabályzat sem tartalmaz részletes tananyag-elöírást, s nem sorolja fel a kötelező tankönyveket sem, következésképp az igen tág hagyományos kereteken belül (grammatika, poétika, retorika, filozófia, vallási ismeretek) nagy szabadságot enged a tanárnak az oktatásban. Nyilvánvalóan ez a szellem és szokásrend érvényesült a debreceni iskolát példaképül tekintő szatmári iskolában is. A már említett tantárgyak mellett Szatmáron is feltehetően a XVII. század végétől követelhették meg fokozottabban a történelem, földrajz, matematika, fizika megtanulását, ugyanis az iskolaszék fegyelmi jegyzőkönyveiben a filozófia, a héber és a görög nyelv tanulásának elhanyagolása miatti megrovások mellett ettől kezdve mind gyakoribb a történelem és a matematika tanulásában elkövetett mulasztások miatti elmarasztalás. ${ }^{50}$

A sárospataki kollégium gimnáziumi osztályainak XVIII. század eleji tantervét ismerjük. Ebből következtethetünk a debreceni kollégium azonos elnevezésű $\mathrm{s}$ a szatmári iskola megfelelő szintű osztályaiban érvényes követelményekre, illetőleg a megkívánt ismeretek körvonalaira is.

Az első gimnáziumi - Sárospatakon declinista (névszóragozónak fordítható), Szatmáron comparatista (összehasonlító) - osztályban elsősorban latin szavakat, a latin nyelv elemeit, a főnévragozást tanulták, bibliai történeteket és némi számtant is (továbbá föként az egyszeregyet gyakorolták). Vallási ismeretekből a tízparancsolat megismerése volt a tananyaguk.

A második - conjugista, magyarul igeragozónak nevezhető - osztályban mindennap latin beszédgyakorlatokat tanultak, egyszerübb latin szövegeket fordítottak, továbbá hétköznapi mondatokat gyakoroltak, ugyancsak latinul. A XVIII. század második felétől bizonyos földrajzi ismereteket is tanultak. A számtantanulás tananyaga az összeadás-kivonás, a hittané pedig a keresztény vallás alapjai voltak.

A grammatisták - a harmadik osztály - már a nyelvtant tanulták. A fötárgy továbbra is a latinból és a latinra fordítás s a nyelvtani szabályok besulykolása. Ebben az osztályban már bizonyos szabad fogalmazásokat is írattak. Számtanból a szorzást, osztást tanulták, hittanból a Heidelbergi Kátét. Ezenkívül zsoltárokat énekeltek. A szintaxisták - a negyedik osztály tananyaga a mondattan volt. Latinból fogalmazási gyakorlatokat végeztek, számtanból az arányszabályt gyakorolták, hittanból folytatták a Heidelbergi Káté tanulását. Az ötödik osztály (a rétorok) szónoklattant tanult. Latinból Cicerót fordították, latin szónoklatokat is kellett

\footnotetext{
${ }^{46}$ A „Szatmárnémeti” helynév 1715 előtt mindig Németire vonatkozik.

${ }^{47}$ Mészáros 1981. 321.

${ }^{48}$ A sárospataki református kollégium. Tanulmányok alapításának 450. évfordulójára. Budapest 1981. 43-46.

${ }^{49}$ Mészáros 1981. 323.

${ }^{50}$ Vö. Matricula studiosorum. 85b-126b.
} 
tartaniuk. Számtanból a különböző számolási módokat oktatták. A hittan és a földrajz tanítása folytatta az előző évben megkezdetteket. A hatodik osztály poétikát tanult, azaz a latin költészet szabályait. Tananyaguk Szenczi Molnár Albert latin grammatikája volt. A latin irodalom klasszikusait - Vergiliust, Ovidiust, Horatiust - fordították. Gyakorlatként - a tehetségesebbek - maguk is írtak latin verseket. A Heidelbergi Káté tanulása ebben az évben is folytatódott, számtanból viszont ismételték a korábban tanultakat.

Sárospatakon a logikusok külön osztályt alkottak, Debrecenben a poétika osztállyal együtt tanultak. Ök összefüggő latin dolgozatokat készítettek, számtanból a tizedes számok rendszerét tanulták. ${ }^{51}$

Az elmondottakból arra következtethetünk, hogy a tananyag elsajátíttatásában bizonyos koncentrikusság ${ }^{52}$ érvényesült, s a tantárgyak osztályonkénti párhuzama lehetővé tette, hogy az alsóbb osztályokban lerakott alapokat évről évre bővítsék. A gimnáziumi osztályok legfontosabb tantárgya a református egyház hittételeinek rendszeres összefoglalása és az egyes tételek értelmezése, bizonyítása volt. Az idézett tantervből láthatjuk, hogy az alsóbb osztályokban ez a Heidelbergi Káté megtanítását és zsoltárok éneklését jelentette.

Szatmáron a retorikai és a poétikai osztályban - a jegyzőkönyvek tanúsítják - a professzor a fentieken kívül héber és görög nyelvet, valamint filozófiát, természetbölcseletet is tanított.

A kétosztályúvá lefokozott iskolában 1754-től csak a latin nyelv elemeit taníthatták. A Helytartótanács azt is megtiltotta, hogy a tanulók felsőbb osztályokra magánúton előkészítést nyerjenek. 1786-ban, amikor elrendelték a német nyelv tanítását, oktatására külön tanári állást létesítettek. ${ }^{53}$

Az 1792. szeptember 2-i egyháztanács-ülés a szatmári iskola számára a debreceni tanítási mód szerint készített tantervi és módszertani utasítást fogad el. Valószínüleg a helyi körülményekhez alkalmazva, kevés módosítással átvették a debreceni gimnázium tantervét. ${ }^{54} \mathrm{~A}$ szatmári tantervi utasítások nem maradtak fenn. Ezt a tantervet 1800-ban módosították, de az újabb tantervből csak a declinista és a conjugista osztályra vonatkozó utalások őrződtek meg.

Az iskola tanítói és tanári kara 1827-ben készített részletes, minden osztály tárgyait és tananyagát kijelölő tantervet ${ }^{55}$, amely a későbbiekben - kevés módosítással - alapját képezte az 1839-ben életbe léptetett, az Organisations Entwurf szerinti átszervezésig érvényben maradt tantervnek. $^{56}$

Mindkét tanterv a debreceni kollégium tantervéhez, tankönyveihez igazodott.

${ }^{51}$ A sárospataki református kollégium. 100-101.

${ }^{52}$ A koncentrikusság elvét akkor mai értelemben nem ismerték.

${ }^{53}$ Bakcsy: i.m. 59.

${ }^{54}$ Konkrétan a debreceni kollégium 1770-ben kiadott, 1791-ben kevés változtatással második kiadásban megjelent rendszeres tantervére, az ún. Methodusra gondolunk.

${ }^{55}$ Bakcsy: i.m. 61-66. Az 1827-ben készített tanterv tankönyvül ajánlhatta Jenei György (szatmári tanácsnok) Katechismus, a debreczeni útmutatásból szedegetve (Kolozsvár 1826) címü könyvét, az 1839-ben életbe lépett tanterv pedig ugyancsak Jenei György Közönséges ó história a tanulók számára (S.Patak 1838) címủ munkáját.

${ }^{56}$ Szövegét Bakcsy idézett könyvének 67-74. lapján közli. 


\section{Az iskola könyvtára, a könyvtárjegyzék oktatástörténeti értékelése}

A XVII-XVIII. századbeli gimnáziumi osztályokban a diákok nem tankönyvekből tanultak, hanem jegyzetből, amit a rektor, illetőleg a professzor előadása nyomán maguk írtak. Nem tudunk e korból fennmaradt jegyzetekröl, tehát nem állapíthatjuk meg a tanított tananyagot sem. Az iskola korabeli könyvtárának ismeretében, bizonyos könyvek jelenlétéből mégis valamelyest következtethetünk az oktatás tartalmára is.

A kollégium könyvtárára vonatkozó első feljegyzés 1632-ből való, azokat a könyveket sorolja fel, amelyeket Bethlen Gábor erdélyi fejedelem adományából vettek. A 38 kötet 44 munkát tartalmaz. Ugyancsak a fejedelem adományából vásárolták meg a könyvtár számára $\mathrm{P}$. Vaari Bálint tanító hagyatékát, 57 könyvet.

Nem tudjuk, hogy ezek előtt hány könyvvel rendelkezett az iskola, azonban bizonyosra vehetjük, hogy valamelyes könyvtára addig is létezett. Az iskola könyvállománya aztán az évek során folyamatosan gyarapodott, ajándékozás és vásárlás útján. A matrikulába azonban csak egyetlen, 1672-ben kapott adománynak, nyolc könyvnek a címét jegyezték fel.

A könyvtár - feltehetőleg - első leltárát 1673-ban készítették. A könyvállomány ekkor 794 kötet. ${ }^{57}$ Mindjárt a következő évben, 1674-ben a könyvállomány jelentősen, a meglevő mennyiségnek közel harminc százalékával gyarapszik, ugyanis Tarczali Bogdány Péter végrendeletileg 250 kötetet hagyományoz a kollégiumra. A következő évekből még négy adományt jegyeztek fel, 1687-ben Pongrácz Menyhért nyolc, 1688-ban Szathmári István hat, Komáromi István egy-egy, 1694-ben Szathmári Sámuel két könyvet adományozott a kollégiumnak. A könyvtár könyvállománya a század végére az ismert adatok szerint immár 1062 kötet.

A feljegyzések szerint az 1703-as tüzvészben a könyvtár java része is odaégett. Újabb adatunk a könyvállományról 1720-ból van, amikor újólag leltározták, most már nem szekrényenként, illetőleg polconként, hanem a szerzők nevének kezdőbetüje szerint. Az egykori gazdag könyvtár most 243 kötetnyire zsugorodott.

A könyvtár további állapotára vonatkozó adat a matrikulában nincs. Tudjuk viszont, hogy 1759-ben egy iskolaügyben a püspökhöz intézett levélhez a gimnáziumi könyvtár katalógusát is csatolták, e szerint a könyvállomány 618 mü. ${ }^{58}$ Ezt követően a könyvtár állománya vásárlások és adományok útján sokat gyarapodott. Erről azonban mindössze az 1781-től vezetett anyakönyv utolsó, megmaradt lapján olvasható két bejegyzés tanúskodik. ${ }^{59}$ Bizonyosan tudjuk azonban, hogy 1856-ban Bartók Gábor igazgató egy régebben készült könyvjegyzék alapján

57 A könyvtárjegyzékeket (Kulcsár György álnéven) A református kollégium könyvtára 1632-1727 címen közöltem. $=$ Partiumi könyvesházak 1623-1730. Budapest-Szeged. A Magyar Tudományos Akadémia Könyvtárának kiadása, 1988. 325-373.

${ }^{58}$ Bakcsy: i.m. 100.

${ }^{59}$ Az anyakönyv utolsó lapján olvasható latin nyelvü bejegyzés szerint 1789-ben egyházi alapból vásárolták és a közösség használatára bocsátották a következő könyveket: Samueli Pavai Catechesis maior, Cellarii Grammatica, Abecedarium Germanicum, Anreae Törsök Languii Colloquia, Josepho Henter Orthographia Hungarica et Abecedarium Germanicum, Georgio Szilasi Hübneri Historiae, Josepho Sárközi Rudimenta Linguae Latinae.

Egy 1790 májusában Gyenge János praeceptor által a tanulók közössége részére vásárolt könyv a Biblia S(acra) Hungarica; 1792-ben Nagy Ari Mihály könyvszerzését jegyezték fel (Psalterium; Compendium historiae sacrae). 
veszi át és rendszerezi a könyvtárat. Ez a jegyzék 2400 kötetet sorol fel, de igen sok, a jegyzékben említett könyv nem volt meg, számos könyv pedig nagyon megrongálódott vagy hiányossá lett, s így csak 970 ép, teljes munkát tud megtartani. A könyvállomány állapota érthető, hiszen a könyvtárnak 1754-től sem állandó helyisége, sem felelős gondozója, könyvtárosa nem volt, a könyvállomány így folyton vándorolt, tanárok, tanítók, lelkészek lakásán helyezték el. ${ }^{60}$

A kollégium könyvtárának ismeretében többé-kevésbé körvonalazhatjuk, hogy az iskola tanárai, tanítói tanultságuk és a tudományokban való jártasságuk alapján milyen bölcseleti és vallási ismeretanyagot használhattak fel az oktatásban, illetőleg mi állott a tanulni, önmagukat elmélyültebben művelni akaró diákok rendelkezésére. ${ }^{61}$

A könyvek között megtalálhatták a különféle természetbölcseleti, valamint vallási irányzatok számos képviselőjének a munkáit. A helvét irányzat vezető teoretikusai közül Kálvin művei Institutio, kommentárok, levelek - mellett tanulmányozhatták az irányzat számos svájci Bullinger, Béza, Oecolompad, Lavater, Musculus, Walther (Gualther), Polanus, Grynaeus -, németországi - Ursinus, Pareus, Scultetus, Piscator, Keckermann, Zanchius, Zepper -, francia - Mornay - és angol - Whitaker, Perkins - teológusának munkáit.

A filippinizmus emlékeként Luther, Melanchton és Brenz müvei is feltünnek. De megtalálhatók az ellenfelek is, föként a katolikus Bellarmina vitairatai. Az érdeklődő olvashatta a szigorú ortodox lutheranizmus képviselőinek, David Chytreus (Kockhaf)-nak és Christofor Pezeliusnak munkáit, a svájci reformáció elleni polemikus irodalmat - Osiander (Hosemann) -, a dán Hemming és az antitrinitarizmus ellen hadakozó Oto Cosmann írásait.

Magyar szerzők közül Kis István, Lisznyai Kovács Pál, Méliusz Juhász Péter és Tolnai Dali János munkáit olvashatták.

Rendelkezésükre állott a Biblia többféle kiadása is, valamint a régi egyházi irodalomból Lactantius és Hieronymus írásai.

A kollégiumi oktatás legfontosabb tantárgya a latin volt. Az alsóbb osztályokban folyó latintanításban használhatták Melanchton nyelvtanát és mondattanát, Ursinus és Bechmann, valamint Szenczi Molnár Albert latin nyelvkönyvét. A latin nyelvi ismeretekben elmélyülő tanulók a latin szavak értelmének megfejtésére elsősorban Szenczi Molnár Albert Dictionarium Latino-hungaricum és Dictionarium hungaro-latinum címü, több példányban is rendelkezésükre álló szótárait használhatták. Emellett a könyvállományban - ugyancsak több példányban - megvolt Calepinus hétnyelvü és tizenegy nyelvű szótára is. Ez utóbbi a szavak magyar megfelelőjét is tartalmazta. Esetenként hasznosíthatták a könyvtár latin-német szótárát (Dictionarium Latino-Germanicum) is.

A két utolsó osztályban a tanulók görög és héber nyelvet is tanultak. A görögöt különféle nyelvtankönyvekből tanulhatták, Clenardi, Melanchton, Neander, Urbanus stb. munkáiból. A görög nyelv tanulásában a latinra is támaszkodhattak, mutatják ezt a könyvtár latin-görög (Pasor: Lexicon graeco-latinum...) és latin-görög-magyar (Dictionarium Latino-GraecoHungarum) szótárai.

${ }^{60}$ Bakcsy: i.m. 100

${ }^{61}$ Nem minden könyvet sikerült azonosítani, mert a feljegyzések némelyike nem könyvcím, csak utalás, jelzés. 
A héber nyelv tanulására föként Johannes Buxtorf nyelvtankönyve. Thesaurus grammaticus linguae Hebreae szolgált, de forgatták Altingus, Bellarmino, Beringer, Melfürher és Paius nyelvtanát is. A szavak értelmezésére Avenarius, Buxtorf szótárát - mindkettő Lexicon Hebraicum -, valamint a Decimatorét - Sylva Hebraeo-Graeco-Latina - használták. A héber nyelvben való jártasság fokozására olvasmányul használhatták a héber nyelvü Bibliát (Biblia Hebraea; Biblia Hebraica) és a héber zsoltároskönyvet (Psalterium Hebraicum).

A három „szent nyelv”-en írt könyveken kívül az állományban más nyelvü kiadványok is voltak: legalább tíz német nyelvü, köztük nyelvtani vonatkozású (Liber Synonimorum Germanicorum), ezenkívül német nyelvü Biblia (Biblia Germanica), 1720 után angol-latin szótár, volt francia szótár is (Dictionarium Gallicum), valamint arab nyelvtan (Thomas Erpenius: Grammatica Arabica).

A magyar nyelvtani ismereteket Szenczi Molnár Albert latin nyelvű magyar nyelvtanából (Novae Grammaticae Ungaricae) tanulhatták. Volt a könyvtárban magyar nyelvü Biblia, s több kötet magyar nyelvü, de latinból átültetett prédikáció, Károlyi Péter, Félegyházi Tamás és Madarász Márton fordításában.

Magyarul írt munkák voltak a Temető praedicatiók Keresztszegi Istvántól, valamint Czeglédi P. István Csatázó lélek diadalma, Barátsági dorgálás, Malach doktor című könyvei.

A kollégium tékája gazdag volt történelmi tárgyú munkákban. Megvolt a könyvtárban Plinius világtörténelme (Historia mundi), Hérodotosz Historiája, Titus Livius római történelme (Rerum Romanorum ab Urbe condita libri), Julius Caesarnak a gall háborúról írt müve (De bello Gallico). A gall háború a tárgya Mercurius könyvének is (Gallo-bellici historicae narrationes). A zsidók történetét Josephus Flavius müvéből (Antiquitates Judaicae), valamint Vosenius munkájából (De antiquis mensuris Hebraeorum) ismerhették meg.

Volt a könyvtárban a lombard, spanyol, egyiptomi stb. történelemröl írt mü is (Historia Lombardica, Historia rerum Hispanicarum, Lusitanarum, Judaicarum et Aetyopicarum).

Olvashatták Bethlen János kancellár latinul írt magyar történelmét is (Rerum Transylvanicarum libri $I V$.), de egyháztörténeti munkákat is tanulmányozhattak (Historia Ecclesiastica). A történelem vitás kérdéseiről szólhatott Vossius könyve, a Controversiae historiae. És persze volt a könyvtárnak Eberi-féle Calendarium Historicum-conscriptuma is.

A XVII-XVIII. századi iskola fontos tantárgya volt a retorika, a szónoklattan tudománya, hozzátartozott az etika is. Szónoklattant Alstedius, Buzinkai Mihály, Dresserus, Isagogus Porphyrius, Ramus, Sturm, Scaliger, Keckermann és Voetius müvei alapján tanulhattak.

A középfokú iskolában számottevő időt fordítottak a diákok vitakészségének kifejlesztésére, s ehhez kapcsolódóan önálló gondolkodásuk alakítására. A szatmári református kollégium diákjai a vitatkozás mesterségét, a dialektikát Sturm és Tittelmann könyvéböl - mindegyik: Dialectica - sajátíthatták el. A dialektikához tartozott a logika tudománya is. Gazdag irodalom állt a diákok rendelkezésére, a szerzők nevének betürendjében: Agricola, Alstedius, Arisztotelész, Dinaerus, Faber, Keckermann, Martinus, Piscator, Ramus, Timplerus, Tolnai Dali János, Zabarella logikája (valamennyi: Logica).

A nevelés kérdéseiről szóló ókori és korabeli munkák is helyt kaptak a könyvtárban, így Plutarkhosz (De libri educendi, De educatione puerorum), Junius (De natura hominis) és Comenius (Orbis sensualium pictus, Janua linguarum) müvei.

A XVII. század első felében - mint ismeretes - az iskolában reál tárgyakat alig vagy keveset tanítottak, és a filozófia járulékos elemeiként magyarázták őket. 
A szatmári kollégiumban - a többi protestáns iskolához hasonlóan - éneket és zenét is tanítottak. Mivel e kollégium a szerényebb anyagi lehetőségekkel rendelkező iskolák közé tartozott, az ének és a zene tanítására a nagyobb diákok közül választott segédtanítót, kántort alkalmaztak. ${ }^{62}$ Az aláírási jegyzőkönyvek tanúsága szerint az idősebb diákok közül 1612-ben Teremi Mihály, 1614-ben Fanczikai István, 1621-től Hadadi István - aki ugyanakkor az iskola szeniora, 1623-ban osztálytanítója (collaboratora) is volt - látta el a kántori teendöket. Minden bizonnyal a későbbiek során is zenében járatosabb nagyobb diákok végezték az ének- és zenetanítás feladatát. A kollégiumi énektanítás anyaga a zsoltártanulás volt, ugyanis a diákoknak közre kellett müködniük a templomi és a temetési éneklésben. Ezért naponta minden lecke előtt és után valamelyik zsoltárból 1-2 verset elénekeltek, szerdán és szombaton pedig (legalábbis 1751-től) az iskola valamennyi tanulója együttesen tanulta a zsoltárokat. $^{63}$

A protestáns kollégiumok énektanításának segédeszköze a XVII. század negyvenes éveitől Geleji Katona István Öreg Graduál (1636) címü munkája volt. E könyv előszava szerint a diákoktól a kottaolvasást is megkívánták. ${ }^{64}$ Feltételezhetjük, hogy a kollégium könyvtárában Gradual Hungaricum néven feljegyzett zsoltároskönyv azonos a Geleji Katona István munkájával.

Nem tudjuk, milyen énekanyagot használtak fel az iskola életében új színt jelentő énekkar létesítésekor. A karéneket a szatmári református kollégiumban - mai ismereteink szerint Bardócz Pál honosította meg 1742-ben ${ }^{65}$ négy-öt évtizeddel megelőzve (Debrecent kivéve) a korabeli testvérkollégiumokat.

\section{Az iskola törvénykönyve}

A diákélet rendjét a kollégiumokban törvények szabályozták, ezeket írásba is foglalták. ${ }^{66}$ Ilyen szabályzat a kollégium kezdeti korszakának törvényeiröl Szatmáron nem maradt fenn, minden bizonnyal az 1703-i tüzvészkor pusztult el. Az 1720-1747 közti időszakból megmaradt iskolaszéki jegyzőkönyvekben azonban a megidézett 192 tógás diák fegyelmi ügyeinek tárgyalásakor gyakran idézik a rendszabályzat megsértett cikkelyeit, illetőleg a kiszabott büntetés alapjául szolgáló rendelkezéseit.

A jegyzőkönyvek az elveszett törvénykönyvnek többnyire a tanulmányokra vonatkozó (De studiis) és a tanulók erkölcseiről szóló (De moribus scholarium) ${ }^{67}$ cikkelyeit emlegetik. Az iskola törvénykönyvének feltételezett, általunk kikövetkeztetett neve: Leges Scholae

\footnotetext{
62 Mészáros 1981. 254.

63 Bakcsy: i.m. 55.

${ }^{64}$ Vö. Benkő: i.m. 140., ahol hivatkozik Szabolcsi Bence A XVIII. század magyar kollégiumi zenéje címü munkájára.

${ }^{65}$ Benkő: i.m. 142., Bartók: i.m. 177.

${ }^{66}$ Thury Etele: Iskolatörténeti adattár. I-II. Pápa 1908. 68-96., Rúzsás: i.m. 15-17., A sárospataki református kollégium. 43.

${ }^{67}$ A törvénykönyvet a Matricula studiosorum jegyzőkönyveiben nem sokszor idézik (a 91-94. lapon), megnevezik viszont a vétséget és az érte kirótt büntetést.
} 
Szathmarinae de studiis, moribus officiisque scholarium. ${ }^{68} \mathrm{~A}$ jegyzőkönyvben elöforduló hivatkozások alapján megállapítható, hogy a szabályzatnak a tanulmányokra vonatkozóan legalább 18, a tanulók erkölcseire vonatkozóan pedig 37 cikkelye bizonyosan volt, ugyanis ilyen számú cikkelyekre is hivatkoznak. Az ügyek tárgyalásakor azonban csak a vétség mibenlétét, a vonatkozó cikkely számát és a kiszabott büntetést tudjuk meg, de a cikkely szövegét nem idézik. Az egyes esetek alapján mégis valamelyest körvonalazhatjuk a szabályzatot, következtethetünk a cikkelyek egy részének a tartalmára.

Az iskolai törvénykönyv kikövetkeztethető cikkelyei, törvényei a következő tartalmúak voltak:

A tanulmányokra vonatkozó fejezetből: 2. cikkely: A vallásos ismeretek tanulásának kötelezettsége; 5.: A tanulásban való előmenetel és a szorgalom kötelezettsége; 7.: A templombajárás kötelezettségei; 8.: A templomban való magatartás és öltözék; 13.: Az éjjeli örség kötelessége; 18.: A kapusszolgálat kötelezettsége.

A tanulók erkölcseire vonatkozó fejezetből: 1. cikkely: Tiszteletteljes beszédmód és viselkedés a vezetőkkel, valamint a városi polgárokkal; 3.: A diáköltözék megállapítása, viseletének elöírása; 6.: A részegeskedés, káromkodás, emberhez nem illő magatartás tiltása; 9.: Az iskolán kívüli viselkedésmód előírásai; a kocsmázás megtiltása; 11.: A botránykeltés elkerülése; 12.: A diáktársak testi sértésének tiltása; 15.: Az iskolából való kiszökés megtiltása; 16.: A kollégiumból való éjszakai (10 óra utáni, éjfél utáni) kimaradás büntetése; 17.: Engedelmesség az elöljárók iránt; a hütlen tisztségviselés megbüntetése; 22.: A dohányzásra vonatkozó rendelkezések; 25.: Az anyagi kártételek megtérítésének módja; a lopás megtérítése; 26.: A szerencsejátékok tiltása; 27.: A legáció kötelezettsége; 28.: Az oeconomus tisztsége és kötelességei; 29.: A szemérmetlen beszédmód tiltása; 31.: A szenior kötelességei, a tisztségviselők iránti engedelmesség kötelezettsége; 34.: A kicsikre (alsóbb osztályok? elemi tagozat?) vonatkozó törvények; 35.: Az iskolaszék meggondolt vezetése; a törvényesség tiszteletben tartása; 37.: Az igazgatás, vezetés törvényei.

A fegyelmi jegyzőkönyvekből megtudjuk tehát, hogy mit vétett a tógás diák, ebből viszont következtethetünk az iskolai törvényekben elöírt kötelezettségeikre.

A diákoknak kötelességük volt pontosan részt venni az órákon, figyelmesen hallgatni a tanár magyarázatait, a tanulásban szorgalmasan bizonyítani.

Mind a leckéken, mind a délutáni templomi könyörgésen köntösben kellett megjelenniük. ${ }^{69}$

A diák engedelmeskedni tartozott a kollégium választott tisztségviselöinek, tilos volt őket sértegetnie. A kisebbeknek hallgatniuk kellett a nagyobbakra.

Tilos volt a verekedés, az önbíráskodás, a bosszúállás, a szolgadiákok és a kisebbek bántalmazása. A szabályzat megkövetelte a diákmivoltukhoz illő beszédmódot és viselkedést. Nem volt szabad a kollégiumból engedély nélkül távozni, kiszökni, sem éjszaka kimaradozni. A szabályzatban elöírt viselkedésmód az iskolán kívül is kötelező volt.

${ }^{68}$ Vö. a debreceni kollégium szabályzatával! Thury: i.m. 68.

${ }^{69}$ A diákviseletet 1624-ben I. Rákóczi György fejedelem állapította meg a váradi zsinat határozata alapján: bokáig érő fekete köntös, fehér gombokkal kapcsolódott; ehhez járult a sárga szegélyes zöld alapú posztószür, az ún. tóga; a diákoknak hosszú, henger alakú nyestbőrből készült kunsüveget, ún. sinkót kellett viselniük; lábbelijük a csizma volt. 1774-ben helyettük a kalpagot és a fekete palástot vezették be. (Vö.: Nagy 1940. 72-74.) 
A tanulóknak számos közösségi feladatuk is volt. A kapunál - természetesen felváltva szolgálatot teljesítettek, éjjel örködtek. Felügyeltek a fózésre. Részt kellett venniük a temetéseken. Az idősebbek közül 3-3 hónapra kántort neveztek ki. Szombatonként a malomban felügyeltek az iskola búzájának az örlésére. A nagyobb diákok legációba is jártak, ezenkívül adományokat gyüjtöttek (supplicálás) a kollégium javára.

A legidősebb diákok közül választották meg a két elemi és a hat gimnáziumi osztály tanítóit, valamint a tisztségviselőket, a seniort, a contrascribát, a könyvtárost, az oeconomust stb.

A jegyzőkönyvek minden egyes fegyelmi eljárás során közlik a kirótt büntetéseket is. A legkisebb büntetés az iskolaszék ülésén elhangzó figyelmeztetés, megintés volt. Ennek is fokozatai voltak, melyeket a vétség súlya szerint alkalmaztak. Némelyik esetben mérsékelt megintésről, dorgálásról, máskor szigorú megintésről tudósít a jegyzőkönyv. Esetenként a fenyítés szót használják.

A büntetés egyik módja a megsértett (egyén vagy közösség) megkövetése volt. Ez lehetett (bocsánat)kéréssel való megkövetés (deprecatio) vagy a vétket a közösség előtt is feltáró és beismerő nyilvános bocsánatkérés (declamatio).

A jegyzőkönyvböl úgy tünik, hogy a súlyosabban vétök ügyét a tanulók közössége meg is vitatta, azaz a közösség is elítélte, megrótta.

A vétkest érzékenyen érintő büntetés volt az ételosztalék megvonása. Gyakori volt a 3 napos ételmegvonás, súlyosabb kihágás esetén egyheti ételmegvonással büntették, előfordult teljes ösztöndíjmegvonás is.

A szolgálatot elmulasztó tanulót újólag beosztották hasonló szolgálat elvégzésére. Soron kívüli éjjeli örségre való beosztással is büntettek.

Számos esetben (s többféle törvénycikk megszegése miatt is) pénzbeli büntetést róttak ki. A legkisebbek a 11-15 dénáros pénzbüntetések voltak, a leggyakoribb a 25 dénáros büntetés; többször 50, 75, ritkábban 100 dénáros büntetést is kiróttak. Az anyagi rongálásért és az elmulasztott kapusszolgálatért mindig 25 dénárt kellett fizetniük. A büntetésböl befolyt pénzösszeg a közösség pénztárát gyarapította.

Gyakori büntetésként a tanulót sorrendben lejjebb helyezték (degradáció). A tanév kezdetén ugyanis, a törvények aláírásakor a tanulók érdemi-tanulmányi sorrendben írták alá a jegyzőkönyvet. A tanév folyamán aztán azért vetélkedtek, hogy a tanulói sorrendben elöbbre kerüljenek. A sorrendben hátrébb kerülni kudarc, szégyen volt. Ezért alkalmazták a tanulói sorrendben hátrább helyezés büntetését. A jegyzőkönyvek bizonysága szerint a vétség súlyától függően alkalmazták; egy, három, nyolc, tíz sorrendi hellyel való degradációkról vannak adataink.

A közösség visszavonhatta a tisztségviselők megbízatását a megbízatás lejárta előtt.

A kollégium szabályzatát nagyon súlyosan megsértő tanulót az iskolából el is távolították. Ennek enyhébbik formája a csendes eltávolítás, kiközösítés (emissio, eliminatio) volt, súlyosabb esetben a megszégyenítéssel való kitaszítás (eiectio).

A szatmári gimnázium első szabályzata megegyező lehetett a debreceni kollégium régi írásban fenn nem maradt - törvényével, amelyre az 1657-ben készült új debreceni szabályzat

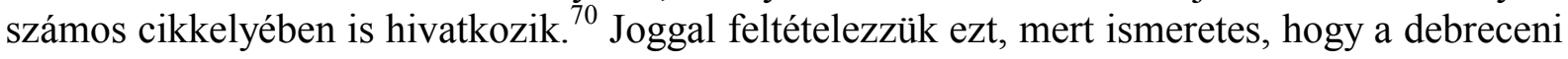

\footnotetext{
${ }^{70}$ Nagy: i.m. 28.
} 
diákok zendülését követően a meglevő iskolai törvényeket éppen az 1627-i szatmári zsinaton toldották meg új, a diáklázadások megbüntetésére vonatkozó cikkellyel. ${ }^{71}$

A legrégebbi iskolai szabályzat valószínűleg csak a tanulók tanulmányi és erkölcsi életét irányító rendelkezéseket tartalmazott, ezért készítették el 1657-ben a debreceni református föiskola új törvénykönyvét, amely egy általános és tizennégy különleges fejezetben pontosan elöírta a rektorok feladatait, körvonalazta a tanulók tanulmányi és erkölcsi kötelezettségeit, a tisztségviselők és a különböző szolgálattevők munkakörét. ${ }^{72}$

Igazodott-e a szatmári gimnázium szokásrendje a megváltoztatott debreceni törvényekhez? Ismert cikkelyei alapján úgy véljük, hogy a szatmári gimnázium jobbára követte az 1657. évi debreceni iskolai szabályzat tanulmányokra vonatkozó fejezetének előírásait, s kisebb módosításokkal átvette a tanulók erkölcsi életére vonatkozó fejezetét. A szatmári kollégium XVII. század végi, XVIII. századi szabályzatából feltételezhetően hiányoztak a tisztségviselők kötelességeire vonatkozó fejezetek, helyettük néhány cikkellyel megtoldották mind a tanulmányokra, mind a tanulók erkölcsi életére vonatkozó fejezetet. Feltételezésünket a szatmári szabályzat ismert cikkelyeinek és a debreceni iskolai törvény vonatkozó fejezeteinek összehasonlítására alapozzuk. Tartalmában egyező a tanulmányokra vonatkozó fejezet 2., 5 ., 7-8. cikkelye. Minden valószínűség szerint a szatmári szabályzatból hiányoztak a filozófiaiteológiai vitákra vonatkozó cikkelyek, ezekre semmilyen utalást sem találtunk. Viszont ehhez a részhez csatolták az éjjeli őrségre, a kapusszolgálatra, a gazdadiák (oeconomus) feladataira vonatkozó rendszabályokat. A tanulók erkölcseire vonatkozó fejezet számos cikkelye $(1,3,6$, 9, 15-16, 22, 31.) egyező, néhány cikkely sorrendi helyéből mégis arra következtetünk, hogy ezen a fejezeten is módosítottak. A debreceni iskolai törvény azonos fejezete 31 cikkelyt tartalmaz, Szatmáron ezt a fejezetet megtoldották néhány, a kollégium vezetésére vonatkozó cikkellyel.

1754 után az iskola működési szabályairól és törvényeiről 1795-ig említés nem történik. Ekkor az egyháztanács egyik jegyzőkönyve említi, hogy az iskola rektora, a lelkész, az egyháztanács fökurátora és ennek helyettese, valamint a tanács egyik tagja megbízást kapott az iskolai szabályok és törvények kidolgozására. ${ }^{73}$ Megbízatásuknak bizonyára eleget tettek, mert 1822-ben érvényes iskolai törvényei voltak a kollégiumnak. Ezeket feltehetően az előzők alapján állították össze. Szövegük így hangzik: ${ }^{74}$

\section{Oskolai törvények}

\section{Cikkely. Az oskolába való járásról}

1. Törvény. A tanulók kötelesek november 1-én, a tanévnyitás napján az iskolában megjelenni.

2. Törvény. Kötelesek pontosan megjelenni a tanítási órákon; nyáron 3/4 8-1/2 11, délután 3/4 3 és 6 óra között; télen 3/4 9-töl 1/2 11-ig, délután 3/4 3-tól 5-ig; az iskolát a tanítás ideje alatt engedély nélkül nem hagyhatják el.

\footnotetext{
${ }^{71}$ Nagy: i.m. 33.

72 Nagy: i.m. 36.

${ }^{73}$ Bakcsy: i.m. 83.

74 A teljes eredeti szöveget vö. Bakcsy: i.m. 84-86. Ezt régies nyelvezete miatt nem közöljük, helyette - a törvények felépítését megőrizve - mai köznyelven a lényegre szorítkozunk.
} 
A késést, mulasztást (hiányzást) igazolniuk kell.

A törvény ellen vétők büntetése: dorgálás, degradálás, az iskola felettes hatóságának való jelentés.

3. Törvény. Az iskolai foglalatosságot délelött, délután énekléssel és imádkozással kezdik, ezen illedelmesen kell viselkedniük.

\section{Cikkely. A tudományok gyakorlásáról}

4. Törvény. Minden tanuló köteles a szükséges (templomi és iskolai) könyveket idejében megszerezni. Könyvek nélkül a diákot nem tekintik iskolai tanulónak.

5. Törvény. Minden tanuló köteles az órákon figyelni, fegyelmezetten viselkedni, a leckét megtanulni, a házi feladatot elkészíteni. A készületleneket megintik, megdorgálják, később degradálják, végül mint korhelyeket az iskolát ellenőrző tanácsbelieknek megbüntetés végett jelentik őket.

Az a tanuló, aki a tananyagot a tanév végéig sem tudja, nem léphet felsőbb osztályba. A tanulókat ismereteik és erkölcsük alapján három csoportba sorolják. A harmadik csoportba helyezettek csak külön vizsga (pótvizsga) alapján léphetnek a következő osztályba.

\section{Cikkely. A templomba való járásról}

6. Törvény. Minden tanuló délelött és délután énekeskönyvvel, rendben, párosával, lárma nélkül köteles megjelenni a templomi éneklésen és imán. Ott a helyhez illően kell viselkedniük; a köztanítóknak rendelt diákoknak hivatalbeli kötelességeiket maradéktalanul teljesíteniük kell.

\section{Cikkely. A tisztességes magaviseletröl}

7. Törvény. Minden tanuló engedelmességgel és tisztelettel tartozik tanítóinak. Az obszervátorok kötelességeiket hüséggel végezzék.

8. Törvény. A tanuló köteles mind az iskolában, mind az iskolán kívül szelíden, jámborul és emberségesen viselkedni; kerülnie kell a civakodást, szitkozódást, kergetőzést, hajigálást, az utcán való lármázást, estéli kóborlást, télen a sikankózást, nyáron a szülői felügyelet nélküli fürdőzést.

Megbüntetik a káromkodást, a trágár és fajtalan beszédet, az orvosi engedély nélküli pipázást, a nyerészkedő játékokat üzőket.

9. Törvény. Minden tanuló köteles a mellette elmenőket illően köszönteni.

10. Törvény. A latinul tanulók kötelesek mind az iskolában, mind azon kívül latinul beszélni; aki ezt nem cselekszi, azt a latin iskolából a magyarba degradálják.

11. Törvény. Tilos más tanuló könyvének, írásának vagy egyéb dolgának ellopása. A másodszor is vétőt kicsapják.

12. Törvény. Tilos a falakra és a kerítésekre való firkálás, festegetés; hasonlóképp bankócédulák (pénz) akár tréfából való rajzolása; tilos a székekre való metszegetés.

13. Törvény. A tanulónak rendes öltözékben, tisztán kell járnia. A piszkos tanulót nem engedik be az iskolába. 
A fenti törvényeket 1846 januárjában még öt ponttal kiegészítették:

1. Rendetlenkedés esetén egyszerre legfeljebb két osztályt engednek ki órák közti szünetre.

2. A tanulók közvetlenül tanítójuk felügyelete alatt állnak, a kihágásokat - azok fokozatai szerint - vagy a tanító, vagy az iskolaszék bünteti.

3. Az iskolában lakó tanítók felügyeleti joga minden osztályra kiterjed, a kihágást elkövetőt vagy saját tanítója, vagy az iskolaszék bünteti.

4. Az iskolaszék tagjai kötelesek az iskolát látogatni, jelenteniük kell az ott vagy másutt tapasztalt rendellenességet.

5. Tilos az iskola kapujában ácsorogni, csoportosulni, a toronyba feljárni, a kútra - a kirendelteken kívül - veszélyes volta miatt járni. 


\section{A kollégium diáksága}

\section{A források}

A kollégium feudalizmus korabeli képét két kiadatlan forrásanyag közlésével, szakszerü feltárásával és feldolgozásával (sok szempontból) jelentősen körvonalazhatjuk, egyúttal a kollégiumról eddig ismert képet is pontosabbá tehetjük.

A feudalizmus korabeli diákság bemutatásakor azokat a szempontokat és elveket érvényesítjük, amelyeket a nagyenyedi kollégium diáknévsorainak bemutatása és elemzése során követtek. ${ }^{75}$ Ez lehetővé teszi az adatok egybevetését, összehasonlítását, s azt, hogy oktatásunkról a későbbiekben megírandó összefoglaló tanulmány alapja egységes elvek és módszerek szerint megszerkesztett anyag legyen.

A két forrás egyike a kollégium tanulóinak aláíási jegyzőkönyve, az ún. Matricula studiosorum $^{76}$, amely 1610-től 1737-ig tartalmazza a kollégiumban tanult felsőbb osztályosok névjegyzékét, s 1720-tól 1747-ig az iskolaszék jegyzőkönyveit; a másik pedig A Szatthmári Ref. Oskolába járt Tanulók Neveiket magába foglaló Könyv, amely nem egyéb, mint az iskolában 1820-1855 közt tanuló diákokról vezetett beírási anyakönyv. ${ }^{77}$

Az iskola tógás tanulóinak nevét 1737 után is bizonyára feljegyezték, a XVIII. század közepéig, de ez a kötet nem maradt ránk, 1754 után pedig az iskola egy időre elvesztette középfokú jellegét. Bizonyosan tudjuk, hogy létezett még egy anyakönyv, amelybe 1781-től 1820 októberéig jegyezték fel az iskola tanulóit, tanítóit, tanárait. Bizonyítékunk az anyakönyv fennmaradt utolsó lapja, valamint a XIX. század első feléből való anyakönyv utolsó lapján olvasható bejegyzés. ${ }^{78}$

Az aláírási jegyzőkönyveket és az iskolaszéki jegyzőkönyveket tartalmazó kézirat 156 lapos, a lapok mérete 29,4/19 cm. A bőrkötésbe a díszítőmotívum közé több helyütt az 1668-as évszámot nyomták. Nyilvánvalóan ez bekötésének időpontja. A kézirat lapjainak vízjele nem egyforma, más vízjelűek a XVII. és ismét más vízjelűek a XVIII. századi rész lapjai. Feltehetően az anyakönyv bekötésekor a régi kéziratot - elörelátóan - üres lapokkal megtoldották.

A kötet általában jónak minősíthető állapotban van, számos lapjának a szélére vékony papírcsíkot ragasztottak a lap további szakadozástól való megóvása érdekében, néhány lapon a kiszakadt részeket ráragasztott papírfolttal toldották meg. Feltehetően az eltévesztett írás helyesbítését célozta három lap alján az eredeti írás leragasztása és átírása, illetőleg négy helyütt két-két lap összeragasztása.

75 Vö. Jakó Zsigmond - Juhász István: Nagyenyedi diákok 1662-1848, valamint Bura László: Szatmári diákok 1610-1852 (a közlés módjáról elmondottakkal).

${ }^{76}$ Részletes leírása a Szatmári diákok 1610-1852 címü kötetben. 5-7.

${ }^{77}$ Részletes leírása uo. 7-8.

78 „Az ezen új Könyv előtt levő, melly az 1781kㅡ Oktoberig eltőlt időt foglalja magában, ezen Oskola Thecajába a' többi Oskola Könyvei közzé tétetvén, [ebben] itt kezdődnek beíródni a Tanúlók neveik." (Vö.: Anyakönyv 509.) 
A kolozsvári Egyetemi Könyvtár restauráló laboratóriumában 1974-ben a kötetet restaurálták, a leragasztott, illetőleg összeragasztott lapokat szétválasztották. Ez utóbbi lehetővé tette, hogy a megfelelő részeket összehasonlítsuk, illetőleg ennek eredményeképp néhány kiegészítést tehessünk.

A kézirat 156 lapjából 31 üres, a többi (a 107-109. lap magyar nyelvü szövegeinek kivételével) latin nyelvü feljegyzéseket tartalmaz.

A matrikula 1610-től 1738-ig tartalmazza a tanulók névsorát. Ez a rész foglalja el a kódex 172. lapját. Ezt követik (a 82. laptól) a jegyzőkönyvek, majd a Cathalogus studiosorum defungentium ab anno 1614 címü - a meghaltakat soroló - fejezet. Ez 194 nevet említ. A továbbiakban (133-137. lap) közli a kollégium könyvtárának teljes jegyzékét 1632-ből és 1673-ból. Ezeket a pénzügyekkel foglalkozó bejegyzések követik (Series pecuniae sacrae ab anno 1675), majd az iskola könyveinek az 1703-as tűzvész után készített új leltára.

A becses iskolatörténeti emlék ma a Királyhágómelléki Református Egyházkerület tulajdonában van. Viszontagságos múltja indokolja féltését, hiszen - amint a fedőlap belső oldalára írt bejegyzés tanúsítja - 1703-ban az égő iskolából, a tüzvészből kellett kimenteni, 1709-ben raboló katona kezéből. És majdnem elveszett akkor is, amikor az egykori iskola tanári könyvtárát az 1960-as években elszállították.

Másik forrásunk az iskola 1820-1855 közti diáknévsorait - az alsóbb osztályok, a polgári iskola és az elemi iskola névsorait is - tartalmazza. A kemény kartonba kötött, bőrrel szegélyezett könyv 254 lapot tartalmaz, a lapok mérete 40,5/25 cm. A fedölapra ragasztott, szív alakú papírlapon ez olvasható: A Szatthmári Ref. Oskolába járt Tanulók Neveiket magába foglaló Könyv.

Az anyakönyv jó állapotban van. 193 lapon (385 oldalon) tartalmazza a tanulók névsorát, 60 lapja üres, a végén pedig az előző anyakönyvre és a kollégium tantestületére vonatkozó bejegyzések találhatók.

Az anyakönyv teljes egészében magyar nyelvü. ${ }^{79}$ A diákok névsorát és adatait ebbe az anyakönyvbe tanáraik, tanítóik jegyezték be. A diákok neve mellett feltüntették apjuk keresztnevét és foglalkozását, a tanulók származási helyét, ha pedig a tanuló Szatmárnémetiben lakott, az utcát is, amelyben lakott.

A rétorok (orátorok) és poéták, tehát a felsőbb osztályosok neve mellé később olykor további pályájukra vonatkozó adatokat is bejegyeztek.

\section{A diáklétszám alakulása}

A kollégium első matrikulája tehát az 1610-1737 közti időszak adatait tartalmazza. Ez alatt a 127 év alatt 82 tanévben vezették be a matrikulába a kollégiumban tanuló nagyobb diákokat. A hiányzó évek egy részében háborús események, máskor járványok akadályozták a kollégium müködését, s ezért maradhatott el a törvény aláírása. Számos esetben azonban nem találjuk kellő magyarázatát az aláírások hiányának. Az bizonyos, hogy a hiányzó évek legtöbbjében is tanítottak a kollégiumban, ha ennek nem is maradt nyoma a matrikulában. Tudjuk például, hogy 1735-ben a diákok hathetes, október 6-tól november 16-ig tartó láza-

79 A magyar nyelvű anyakönyvezésben a szatmári református gimnázium megelőzte a többi gimnáziumot, ugyanis Eperjesen is - az iskolatörténet ezt tartja a legkorábbinak - csak 1840-1841ben vezették be. Vö. Bajkó: i.m. 166. 
dása, illetőleg az ezzel kapcsolatos fegyelmi intézkedések folytán jelentősen megfogyatkozott a tógás diákok létszáma, csak 18 diák maradt meg a kollégiumban, majd decemberben a létszám pótlására a debreceni kollégiumból 12 jó erkölcsủ tógás diákot küldtek. ${ }^{80}$ És tanítottak a kollégiumban 1737 után is, hiszen a matrikulában található fegyelmi jegyzőkönyvek, valamint a közpénztár bejegyzései még további 21 olyan évből őriztek meg tanulóneveket, néha 30-40-et is, amelyekből nem maradt ránk subscriptiós névsor.

A matrikulába foglalt tanulói létszámot sem tekinthetjük teljesnek, mert - amint erre a Bethlen Kollégiumról írt tanulmányában Jakó Zsigmond már rámutatott - subscriptióra az egykori kálvinista kollégiumokban csak az ún. studiosusok, azaz tógát öltött, felsőbb éves „deákok” voltak kötelezve. Hiánytalanul közülük is csak a kollégiumban bentlakó ösztöndíjasok (alumnus) szerepeltek. A városi polgároknál szállást tartó vagy saját háztartást vivő ún. publicusok neve a XIX. század elejéig csak elvétve bukkan fel a matrikulák lapjain. ${ }^{81}$ De nem ismerjük a szolgadiákok számát sem. Erre esetünkben mindössze egy 1754-ben készült jegyzőkönyv utal, amely szerint a tógás diákok mellett ugyanannyi a szolga. ${ }^{82}$

1747-et követően 1820-ig egyáltalán nincsenek a diáklétszámra vonatkozó adataink. Az azonban bizonyos, hogy az 1781-1820 közötti időszakban is létezett iskolai anyakönyv, amelybe az iskola tanulóit bevezették. Ez azonban elveszett. E matrikula megmaradt egyetlen, utolsó lapján olvasható feljegyzésben az iskola rektora összegzi az anyakönyvben foglalt időszak osztályszerkezetét, vagyis az osztályok felépítését a 39 tanév során. Az utolsó lap alján ez olvasható:

\section{„Jegyzés}

Három ízben 3-3 Classisokra voltak osztva a Tanulók 11 esztendő alatt

Két ízben 2-2 Classisokra voltak osztva a Tanulók 6 esztendő alatt

Négy Classis állván elő tartott az úgy 14 esztendeig.

Öt Classis támadván fenn áll már 8 esztendő olta.

Az 1820. évi Octóbertől fogva valók az Új Könyvben találtatnak, e’ pedig bétetett a Thecaba.

$$
\text { Signavit Vajai R., }{ }^{83}
$$

Az 1820-1852 közti tanévekről vezetett anyakönyv - az 1820. évi kivételével ${ }^{84}$ - minden évben pontosan közli a diáklétszámot. A szatmári református kollégium felsőbb osztályaiba e három évtized során 951 tanuló járt.

\footnotetext{
${ }^{80}$ Kovács: i.m. 20.

${ }^{81}$ Jakó Zsigmond - Juhász István: i.m. 43.

${ }^{82}$ Kovács: i.m. 25.

${ }^{83}$ Az elveszett matricula egyetlen megtalált lapját az 1610-es matricula kéziratának 159. lapja után beragasztottuk.

${ }^{84}$ 1820-ban Országh Pál nem vezette be a Nagyobb Magyar Fiú Oskolába járó diákokat. Az anyakönyv negyedik lapján a kollégiumba járó grammatisták névsora után ez a bejegyzés olvasható: „Itt rendszerént következtek vólna az Országh Pál ér Tanítványi, de Tanítói hivatalában itt már bizonnyal esendő változását okozott bajainál fogva lett bosszús restsége miatt f[el] n[em] jegyzette."
} 
A két matrikula összesen 4148 beírt felsőbb osztályos tanuló nevét tartalmazza.

A felsőbb éves diákok létszáma a kollégium történetének régebbi és újabb korszakában is, de az egyes korszakokon belül tanévenként is nagyon változó volt.

Az 1610-1737 közti évek létszámingadozását jól szemlélteti a következő táblázatunk:

\begin{tabular}{ccccccccccccc}
\hline $\begin{array}{c}\text { A } \\
\text { tanulók } \\
\text { száma }\end{array}$ & $\begin{array}{c}\text { Tíznél } \\
\text { kevesebb } \\
(6-9)\end{array}$ & $10-19$ & $20-29$ & $30-39$ & $40-49$ & $50-59$ & $60-69$ & $70-79$ & $80-89$ & 105 & 129 & 149 \\
\hline $\begin{array}{c}\text { Hány } \\
\text { (tan)- }\end{array}$ & & & & & & & & & & & & \\
évben? & 11 & 2 & 14 & 16 & 14 & 5 & 5 & 3 & 1 & 1 & 1 & 1 \\
\hline
\end{tabular}

Az 1610-et követő évtizedben folyamatosan, minden évben bejegyezték az iskolában tanulók neveit, évenkénti létszámuk ebben az évtizedben kiegyensúlyozottnak tekinthető. 1621-1629 közt már nagyobb ingadozások tapasztalhatók, az egymást követö években 50 , majd 7 , majd 58 diák írta alá az iskola törvényeit.

Nyitott kérdés marad, hogy 1628 és 1631 közt miért nincs a matrikulában semmilyen bejegyzés. A változó politikai-közigazgatási viszonyok folytán nem tanítottak az iskolában, vagy csupán - talán az események hatására - nem készült aláírási jegyzőkönyv?

1632-től öt éven át ismét folyamatos a matrikula. 1634-ben ugrásszerüen megnövekedett a tógás diákok száma, 58-an írták alá a matrikulát. Ismét öt éves ür következik, majd 1641-et követően a hetvenes évekig egy-két évre ismételten, többször is megszakad a matrikula folytonossága. Nem írták alá a törvényeket 1642-ben, 1644-ben, 1645-ben, 1648-ban, 1651ben, 1653-ban, 1659-ben, 1661-ben, 1663-ban és 1670-ben. A negyvenes évek közepétől a hetvenes évekig a létszám az előző évtizedek átlagánál jóval nagyobb, többnyire negyvenen felüli, sokszor haladja meg a hatvanat.

1671-től a matrikulát folyamatosan vezették 1703-ig, a város kuruc uralom alá jutásának időpontjáig. Ez alatt a három évtized alatt a tanulók létszáma nagyon változó. A hetvenes évek végétől néhány év $(1675,1678,1684,1688,1697,1703)$ kivételével a tanulók létszáma viszonylag alacsony.

Az ostrom idején leégett iskola csak négy év múlva folytatta tevékenységét, s ekkor, 1707-ben készült is aláírási jegyzőkönyv, ezt követően azonban csak 1713-ban, s az utolsó jegyzőkönyv időpontjáig, 1737-ig még hétszer, többnyire nem egymást követő években. Ebben az időszakban a diákok száma igen megnövekedett. ${ }^{85}$

Az anyakönyv utolsó lapján írt feljegyzésben pedig ez olvasható:

„Ezen újabb Könyvböl pedig ki lehet látni

1. Hogy Ország Pál Úrnak, ki még a más Könyvben feljegyzett, és még tán 1811-ben Nagy Bányáról hozatott tanítónak (:meghalván az az előtt több esztendeig is volt Bottyán János érdemes tanító:) Tanítványi nincsenek feljegyezve, mivel 1822-ben Hivatalából ki esett...”

${ }^{85}$ Volt olyan év, amikor 129, másikban 149 diák írta alá a jegyzőkönyvet. Minthogy ez utóbbi esetben két jegyzőkönyvről van szó, az egyiket tavasszal írták, a másikat ősszel, novemberben, elképzelhetö, hogy az egyik nem az adott évre vonatkozott, hanem a megelőző évét pótolta, esetleg a következő évét jelenti. A helyes létszám ez esetben 60 körüli lehetett. 
Ismeretes még az 1754. évi létszám, ugyanis a helytartótanács megbízottjának a kollégium lefokozása előtt benyújtott jelentése szerint ekkor a kollégiumban 40 tógás diák volt. ${ }^{86}$

1820-tól a harmincas évek elejéig az osztályok létszáma általában 33-35, néhány évben (1828, 1829, 1831) negyvenen felüli. A harmincas években kevesebben tanulnak, az átlag 30-ra, a negyvenes években még tovább, 25-re csökken.

A XIX. századból való Anyakönyv minden évben közli az iskola alsóbb osztályaiba járt tanulók számát is, valamint az ún. Nagyobb Fiú Oskola (a későbbi polgári iskola) és a Kisebb Magyar Fiú Oskola, azaz az elemi iskola tanulóinak létszámát is.

A kollégium alsó osztályaiba a három évtized alatt 3515 tanuló járt, a Nagyobb Magyar Fiú Oskolába, illetőleg a polgáriba 2855. A kollégium alsóbb osztályainak látogatottsága 18211835 közt évi átlagban 140 tanuló, míg a Nagyobb Magyar Fiú Oskoláé ugyanebben az időben átlag 60 tanuló. Ez az arány jelentősen megváltozik a polgári iskola megalakulása után. Ezt követően az alsóbb osztályok átlaga 74 tanuló (egyes években csak 33, 44, 46), míg a polgári iskoláé ugyanebben az időszakban átlag 118-ra növekszik. A polgári iskolában mindössze két tanévben alacsony a tanulók létszáma, 1842-ben (50) és 1847-ben (35).

Az elemi iskola I-III. osztályában 1820-1855 közt, tehát a három és fél évtized alatt 4965 tanuló járt, évi átlagban 141-142. Kevés elemi iskolás (82-86) csak 1820-ban, 1831-ben, 1833-ban és 1834-ben volt. Az elemiben tanulók létszáma több évben kétszázon felüli is volt. Így 1826-ban 261, 1844-ben 205, 1848-ban 230, 1849-ben 225.

Az iskola összes tanulóit számba véve azt kell megállapítanunk, hogy a XIX. század három és fél vizsgált évtizedében évi átlagban több mint 350 diák tanult az iskola falai közt, összlétszámuk öt tanulmányi évben meghaladta a négyszázat, egyben az ötszázat.

Az 1. számú táblázatunk a kollégiumban a XIX. század első felében anyanyelven müködő osztályok felépítését, létszámát mutatja be, a 2. számú táblázat pedig a latin nyelvű kollégiumi osztályok létszámát is, az anyanyelvüekét is.

\footnotetext{
${ }^{86}$ Kovács: i.m. 25.; Bakcsy: i.m. 15.
} 


\section{1. számú táblázat}

A kollégium keretében működő anyanyelvű osztályok

- polgári és elemi iskola - tanulóinak létszáma

1820-1855 közt

\begin{tabular}{ccc}
\hline Év & Nagyobb Magyar Fiú Oskola & Kisebb Magyar Fiú Oskola \\
\hline 1820 & - & 84 \\
1821 & 54 & 120 \\
1822 & 67 & 118 \\
1823 & 47 & 123 \\
1824 & 43 & 143 \\
1825 & 52 & 149 \\
1826 & 68 & 261 \\
1827 & 56 & 153 \\
1828 & 61 & 124 \\
1829 & 76 & 123 \\
1830 & 60 & 149 \\
1831 & 63 & 86 \\
1832 & 51 & 101 \\
1833 & 56 & 85 \\
1834 & 81 & 82 \\
1835 & 89 & 105 \\
1836 & 63 & 115 \\
& &
\end{tabular}


Ev

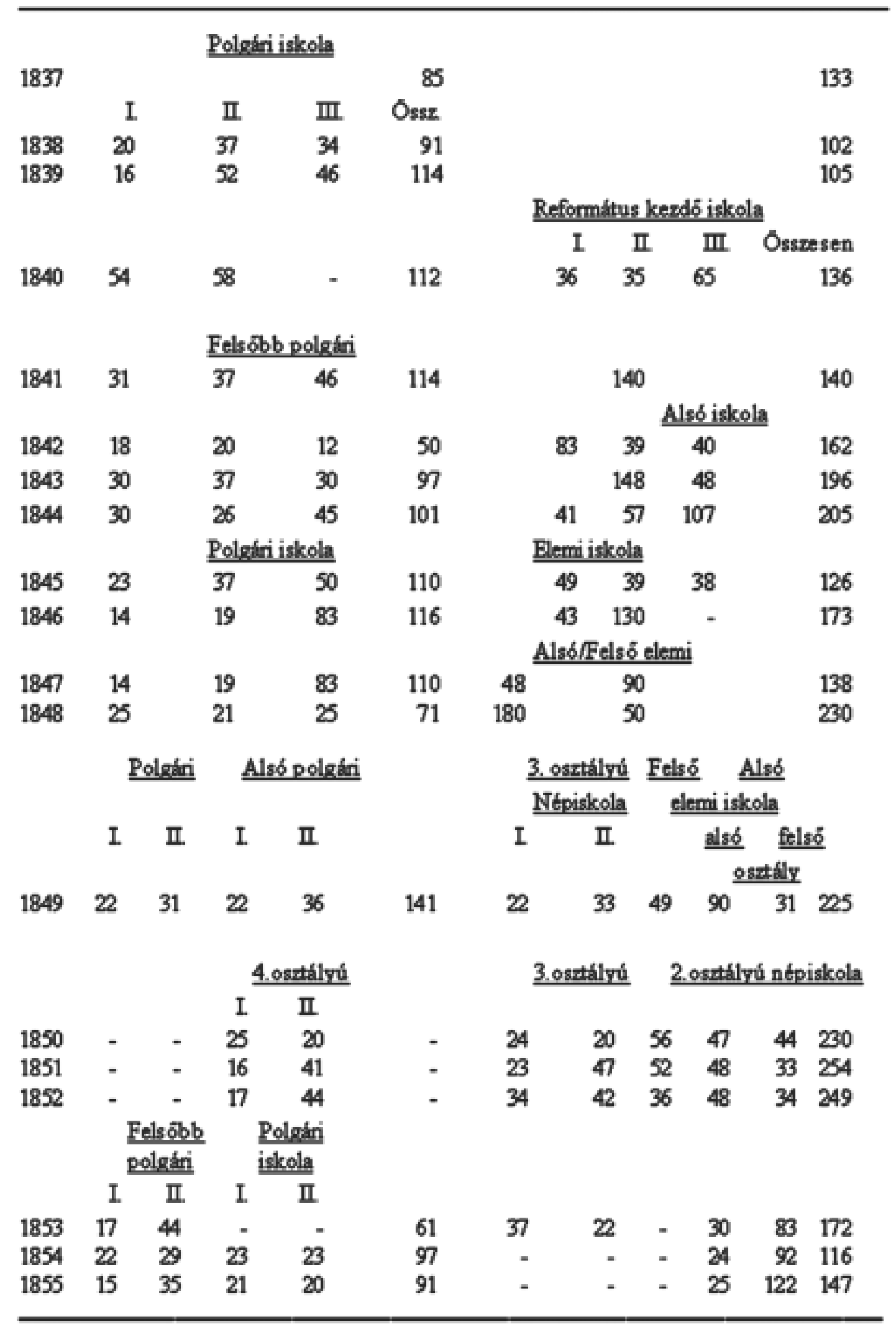




\section{2. számú táblázat}

Összesítő táblázat a kollégiumban 1820-1855 közt tanult diákokról

\begin{tabular}{|c|c|c|c|c|c|}
\hline \multirow[t]{2}{*}{ Év } & \multicolumn{2}{|c|}{ Kollégium } & \multirow{2}{*}{$\begin{array}{l}\text { Nagyobb magyar } \\
\text { Fiú Oskola } \\
\text { Polgári iskola } \\
\text { 1837-től }\end{array}$} & \multirow{2}{*}{$\begin{array}{l}\text { Elemi } \\
\text { osztályok } \\
\text { I-III. }\end{array}$} & \multirow[t]{2}{*}{ Összesen } \\
\hline & $\begin{array}{l}\text { Felső } \\
\text { osztályok }\end{array}$ & $\begin{array}{l}\text { Alsó } \\
\text { osztályok }\end{array}$ & & & \\
\hline 1820 & 35 & 92 & - & 84 & 211 \\
\hline 1821 & 33 & 121 & 54 & 120 & 328 \\
\hline 1822 & 36 & 136 & 67 & 118 & 357 \\
\hline 1823 & 27 & 156 & 47 & 123 & 353 \\
\hline 1824 & 37 & 163 & 43 & 143 & 386 \\
\hline 1825 & 34 & 171 & 52 & 149 & 406 \\
\hline 1826 & 34 & 139 & 68 & 261 & 502 \\
\hline 1827 & 38 & 153 & 56 & 153 & 400 \\
\hline 1828 & 44 & 132 & 61 & 124 & 361 \\
\hline 1829 & 48 & 118 & 76 & 123 & 365 \\
\hline 1830 & 34 & 144 & 60 & 149 & 387 \\
\hline 1831 & 41 & 128 & 63 & 86 & 318 \\
\hline 1832 & 28 & 160 & 51 & 101 & 340 \\
\hline 1833 & 25 & 155 & 56 & 85 & 321 \\
\hline 1834 & 24 & 114 & 81 & 82 & 301 \\
\hline 1835 & 23 & 119 & 89 & 105 & 336 \\
\hline 1836 & 33 & 95 & 63 & 115 & 306 \\
\hline 1837 & 34 & 80 & 85 & 133 & 332 \\
\hline 1838 & 26 & 81 & 91 & 102 & 300 \\
\hline 1839 & 29 & 66 & 114 & 105 & 314 \\
\hline 1840 & 22 & 72 & 112 & 136 & 342 \\
\hline 1841 & 26 & 46 & 114 & 140 & 326 \\
\hline 1842 & 20 & 89 & 50 & 162 & 321 \\
\hline 1843 & 25 & 94 & 97 & 196 & 412 \\
\hline 1844 & 23 & 84 & 101 & 205 & 413 \\
\hline 1845 & 21 & 93 & 110 & 126 & 350 \\
\hline 1846 & 32 & 84 & 116 & 173 & 405 \\
\hline 1847 & 32 & 77 & 35 & 137 & 281 \\
\hline 1848 & 27 & 44 & 71 & 230 & 372 \\
\hline 1849 & 24 & 33 & 111 & 225 & 393 \\
\hline 1850 & 21 & 46 & 89 & 147 & 303 \\
\hline 1851 & 15 & 50 & 127 & 133 & 328 \\
\hline 1852 & - & 57 & 137 & 118 & 312 \\
\hline 1853 & - & 57 & 120 & 113 & 290 \\
\hline 1854 & - & 66 & 97 & 116 & 279 \\
\hline 1855 & - & - & 91 & 147 & 238 \\
\hline Össze & 951 & 3515 & 2855 & 4965 & 12286 \\
\hline
\end{tabular}




\section{A diákok származáshelye}

A XVII-XVIII. századi szatmári diákok származási helyének megállapítása igen nehéz. Jelentős többségük esetében a családnevük igazít el. Ez azért lehetséges, mert a családnevek kialakulásának és megszilárdulásának kezdeti korszakában a nevek többsége a származás helyét feltüntető helységnévből képzett. S ugyanehhez a csoporthoz sorolhatók a megye- vagy tájegységnevet tartalmazó családnevek is. A vizsgált matrikulák éppen a családnevek megszilárdulásának korából valók, ami a birtokos osztálynál zömében a XV. század körüli időre, az alsóbb néprétegeknél pedig zömében a XVI-XVIII. századra tehető. ${ }^{87}$

E nyelvtörténeti és társadalomtörténeti tények mérlegelése alapján követjük mi is Jakó Zsigmond eljárását, aki 1740-ig minden diákot abból a helységből valónak minősít, amelyikre a neve utal. ${ }^{88}$

Néhány birtokos nemes származásának valószínüsítésében segítségünkre volt Szatmár vármegye monográfiája. ${ }^{89}$

A szász tanulók a subscriptiókor családnevük mellé bejegyezték származási helyüket is (Cibiniensis, Nagyschelkensis stb.). ${ }^{90}$

Nehézséget jelentettek azok a származási helyet (vagy a birtokot) feltüntető családnevek, amelyek egyszerre több megyében is elöforduló azonos nevü helységekre (pl. Daróc) utalhatnak. Számos ilyen esetben a nevét bejegyző egy-egy betüvel eligazít, esetleg a tájegység megjelölésével segít (K.Namény: Kisnamény, P.Daróc: Pusztadaróc, K.Daróc: Királydaróc, Almasi, Transylvanus).

Máskor a falu földrajzi helyzete és korabeli felekezeti hovatartozása révén valószerüsíthettük a származási helyet. Ha egyik módon sem sikerült, akkor az olyan neveket, amelyekből több is volt az adott korban (Szentgyörgy, Szentpéter stb.), inkább a bizonytalanok kategóriájába soroltuk, hogy ne csökkentsük adataink hitelét.

A XIX. századi beírási anyakönyv kevés kivétellel minden diák származási helyét is közli.

A szatmári református kollégium diákságának származási hely szerinti összetétele felől három táblázatunk és az azok alapján készült grafikon tájékoztat. A 3. számú táblázat évenként, a 4. számú táblázat pedig évtizedenként összesítve és százalékban kifejezve mutatja, hogy hány diák tanult a kollégiumban Szatmár megyéből, hányan jöttek az erdélyi megyékből, a Székelyföld, a Szászföld településeiröl, hányan az Erdélyen kívüli területekröl, illetőleg hánynak maradt bizonytalan a származási helye. Az 5. számú táblázat afelöl igazít el, hogy a Szatmár megyéből származó diákok közül a XIX. században hányan származtak Szatmárnémetiböl és hányan a megyebeli falvakból.

${ }^{87}$ Vö. Bárczi Géza - Benkő Loránd - Berrár Jolán: A magyar nyelv története. Tankönyvkiadó, Budapest 1967. 378-84.; Kálmán Béla: A nevek világa. Gondolat, Budapest 1969. $72-73$.

${ }^{88}$ Jakó: i.m. 58.

${ }^{89}$ Borovszky: i.m.

${ }^{90}$ A helységneveket 1808-ban számba vevő kimutatásból az derül ki, hogy ekkor az országban 52 Keresztúr, 20 Szentandrás, 8 Szentbenedek, 59 Szentgyörgy, 32 Szentiván, 27 Szentkirály, 56 Szentmárton, 15 Szentpál, 51 Szentmihály, 34 Szentpéter nevü helységet tartottak számon. Vö. Kálmán: i.m. 155. 


\section{3. számú táblázat}

A tógás diákok létszáma, származási helye

\begin{tabular}{|c|c|c|c|c|c|c|c|}
\hline Év & $\begin{array}{l}\text { Lét- } \\
\text { szám }\end{array}$ & $\begin{array}{l}\text { Szatmár } \\
\text { megye }\end{array}$ & $\begin{array}{l}\text { Erdélyi } \\
\text { megyék }\end{array}$ & $\begin{array}{l}\text { Székely } \\
\text { székek }\end{array}$ & $\begin{array}{l}\text { Szász } \\
\text { székek }\end{array}$ & $\begin{array}{l}\text { Erdélyen } \\
\text { kívüli }\end{array}$ & $\begin{array}{l}\text { Bizony- } \\
\text { talan }\end{array}$ \\
\hline 1610 & 34 & 8 & 7 & - & - & 16 & 3 \\
\hline 1611 & 24 & 7 & 7 & 1 & 1 & 8 & - \\
\hline 1612 & 36 & 14 & 4 & - & 2 & 15 & 1 \\
\hline 1613 & 18 & 7 & 3 & 1 & - & 7 & - \\
\hline 1614 & 30 & 9 & 4 & 1 & - & 15 & 1 \\
\hline 1615 & 29 & 9 & 6 & - & - & 14 & - \\
\hline 1616 & 11 & 3 & 1 & - & - & 7 & - \\
\hline 1617 & 21 & 13 & 2 & - & - & 6 & - \\
\hline 1618 & 24 & 11 & 3 & 1 & - & 8 & 1 \\
\hline 1619 & 24 & 5 & 4 & - & 1 & 11 & 3 \\
\hline 1620 & 10 & 3 & - & - & - & 7 & - \\
\hline 1621 & 50 & 10 & 12 & - & - & 28 & - \\
\hline 1622 & 7 & - & 1 & 1 & - & 5 & - \\
\hline 1623 & 58 & 20 & 7 & - & - & 29 & 2 \\
\hline 1624 & 39 & 14 & 7 & 1 & 3 & 13 & 1 \\
\hline 1625 & 23 & 7 & 2 & - & - & 14 & - \\
\hline 1626 & 20 & 7 & 1 & 1 & - & 11 & - \\
\hline 1627 & 31 & 8 & 3 & 2 & - & 16 & 2 \\
\hline 1632 & 30 & 11 & 3 & 2 & 5 & 8 & 1 \\
\hline 1633 & 25 & 10 & 1 & 1 & 1 & 12 & - \\
\hline 1634 & 78 & 35 & 3 & 1 & - & 38 & 1 \\
\hline 1635 & 24 & 13 & 2 & 1 & 1 & 6 & 1 \\
\hline 1636 & 18 & 4 & 1 & 1 & - & 11 & 1 \\
\hline 1641 & 37 & 15 & 5 & 1 & - & 15 & 1 \\
\hline 1643 & 7 & 3 & - & 1 & - & 2 & 1 \\
\hline 1646 & 60 & 20 & 9 & 4 & - & 26 & 1 \\
\hline 1647 & 45 & 19 & 6 & 6 & 2 & 9 & 3 \\
\hline 1649 & 38 & 12 & 5 & 5 & - & 15 & 1 \\
\hline 1650 & 40 & 14 & 5 & 3 & 1 & 16 & 1 \\
\hline 1652 & 69 & 12 & 10 & 11 & 7 & 22 & 7 \\
\hline 1654 & 42 & 12 & 11 & 4 & 4 & 7 & 4 \\
\hline 1655 & 46 & 18 & 6 & 8 & 3 & 7 & 4 \\
\hline 1656 & 57 & 22 & 7 & 4 & 3 & 18 & 3 \\
\hline 1657 & 45 & 22 & 4 & 2 & - & 15 & 2 \\
\hline 1658 & 63 & 24 & 10 & 4 & 1 & 20 & 4 \\
\hline 1660 & 47 & 19 & 5 & - & - & 19 & 4 \\
\hline 1662 & 42 & 20 & 3 & 2 & - & 13 & 4 \\
\hline 1664 & 35 & 13 & - & 2 & 1 & 18 & 1 \\
\hline 1665 & 63 & 14 & 3 & 2 & 2 & 39 & 3 \\
\hline 1666 & 70 & 21 & 4 & 5 & 5 & 35 & - \\
\hline 1669 & 69 & 21 & 5 & 1 & - & 37 & 5 \\
\hline 1671 & 27 & 6 & 1 & - & - & 18 & 2 \\
\hline 1672 & 19 & 6 & 1 & - & - & 10 & 2 \\
\hline 1673 & 8 & 1 & - & 1 & 1 & 4 & 1 \\
\hline 1674 & 15 & 7 & - & - & - & 7 & 1 \\
\hline 1675 & 45 & 13 & 1 & - & - & 28 & 3 \\
\hline
\end{tabular}




\begin{tabular}{|c|c|c|c|c|c|c|c|}
\hline Év & $\begin{array}{l}\text { Lét- } \\
\text { szám }\end{array}$ & $\begin{array}{l}\text { Szatmár } \\
\text { megye }\end{array}$ & $\begin{array}{l}\text { Erdélyi } \\
\text { megyék }\end{array}$ & $\begin{array}{l}\text { Székely } \\
\text { székek }\end{array}$ & $\begin{array}{l}\text { Szász } \\
\text { székek }\end{array}$ & $\begin{array}{l}\text { Erdélyen } \\
\text { kívüli }\end{array}$ & $\begin{array}{l}\text { Bizony- } \\
\text { talan }\end{array}$ \\
\hline 1676 & 10 & 4 & 1 & 1 & - & 3 & 1 \\
\hline 1677 & 10 & 6 & 1 & - & - & 3 & - \\
\hline 1678 & 41 & 14 & 3 & - & - & 22 & 2 \\
\hline 1679 & 9 & 3 & 1 & - & - & 4 & 1 \\
\hline 1680 & 17 & 6 & 2 & - & - & 9 & - \\
\hline 1681 & 6 & 2 & - & - & 1 & 2 & 1 \\
\hline 1682 & 8 & 3 & 1 & - & - & 3 & 1 \\
\hline 1683 & 7 & 3 & 1 & - & - & 3 & - \\
\hline 1684 & 41 & 17 & 2 & 1 & - & 19 & 2 \\
\hline 1685 & 24 & 7 & 1 & - & - & 13 & 3 \\
\hline 1686 & 34 & 12 & 3 & - & - & 17 & 2 \\
\hline 1687 & 14 & 4 & 1 & 1 & - & 8 & - \\
\hline 1688 & 42 & 23 & 3 & - & - & 15 & 1 \\
\hline 1689 & 13 & 6 & - & - & - & 7 & - \\
\hline 1690 & 10 & 3 & 1 & - & - & 6 & - \\
\hline 1691 & 15 & 9 & - & - & - & 5 & 1 \\
\hline 1692 & 14 & 3 & 1 & - & - & 10 & - \\
\hline 1693 & 7 & 4 & - & - & - & 3 & - \\
\hline 1694 & 33 & 17 & 1 & - & - & 14 & 1 \\
\hline 1695 & 8 & 2 & - & - & - & 4 & 2 \\
\hline 1696 & 11 & 4 & - & - & - & 4 & 3 \\
\hline 1697 & 39 & 11 & - & - & - & 20 & 8 \\
\hline 1698 & 13 & 5 & 1 & - & 1 & 6 & - \\
\hline 1699 & 19 & 10 & 1 & 1 & - & 7 & - \\
\hline 1700 & 7 & 2 & - & 1 & - & 3 & 1 \\
\hline 1701 & 16 & 5 & 2 & - & - & 9 & - \\
\hline 1702 & 15 & 2 & 1 & 2 & - & 10 & - \\
\hline 1703 & 52 & 20 & 6 & 1 & - & 21 & 4 \\
\hline 1707 & 41 & 8 & 9 & 1 & - & 18 & 5 \\
\hline 1713 & 30 & 7 & 6 & 1 & - & 11 & 5 \\
\hline 1714 & 77 & 16 & 10 & 2 & - & 41 & 8 \\
\hline 1719 & 106 & 24 & 15 & - & - & 61 & 6 \\
\hline 1720 & 12 & 2 & - & 1 & - & 6 & 3 \\
\hline 1721 & 17 & 6 & 2 & - & - & 8 & 1 \\
\hline 1722 & 13 & 4 & - & 1 & - & 7 & 1 \\
\hline 1723 & 56 & 11 & 15 & - & - & 27 & 3 \\
\hline 1724. nov. & 61 & 41 & 30 & - & - & 77 & 3 \\
\hline 1725 & 7 & 2 & 2 & - & - & 1 & 2 \\
\hline 1726 & 23 & 7 & 2 & - & - & 12 & 2 \\
\hline 1727 & 27 & 12 & - & - & - & 10 & 5 \\
\hline 1728 & 30 & 9 & 1 & - & - & 17 & 3 \\
\hline 1729 & 133 & 39 & 19 & 2 & - & 61 & 12 \\
\hline 1730 & 1 & - & - & - & - & - & 1 \\
\hline 1731 & 37 & 8 & 2 & 1 & - & 19 & 7 \\
\hline 1732 & 43 & 12 & 1 & - & - & 21 & 8 \\
\hline 1733 & 41 & 13 & 4 & - & - & 16 & 7 \\
\hline 1734 & 29 & 11 & 3 & - & - & 10 & 5 \\
\hline 1735 & 39 & 11 & 1 & - & - & 18 & 9 \\
\hline 1736 & 2 & 1 & - & - & - & 1 & - \\
\hline
\end{tabular}




\begin{tabular}{lccccccc}
\hline Év & $\begin{array}{l}\text { Lét- } \\
\text { szám }\end{array}$ & $\begin{array}{l}\text { Szatmár } \\
\text { megye }\end{array}$ & $\begin{array}{l}\text { Erdélyi } \\
\text { megyék }\end{array}$ & $\begin{array}{l}\text { Székely } \\
\text { székek }\end{array}$ & $\begin{array}{l}\text { Szász } \\
\text { székek }\end{array}$ & $\begin{array}{l}\text { Erdélyen } \\
\text { kívüli }\end{array}$ & $\begin{array}{l}\text { Bizony- } \\
\text { talan }\end{array}$ \\
\hline 1737 & 80 & 22 & 9 & 6 & - & 32 & 11 \\
1738 & 2 & 1 & - & - & - & 1 & - \\
1739 & 2 & 2 & - & - & - & - & - \\
1740 & 2 & - & - & - & - & 1 & 1 \\
1741 & 2 & - & - & - & - & - & 2 \\
1742 & 2 & 1 & - & - & - & - & 1 \\
1746 & 2 & - & - & - & - & 1 & 1 \\
1747 & 2 & - & - & - & - & 1 & 1 \\
\hline 1820 & 35 & 35 & - & - & - & - & - \\
1821 & 35 & 32 & - & - & - & 1 & - \\
1822 & 36 & 34 & 1 & - & - & - & 1 \\
1823 & 27 & 27 & - & - & - & - & - \\
1824 & 37 & 35 & - & - & - & 2 & - \\
1825 & 34 & 33 & - & - & - & 1 & - \\
1826 & 34 & 32 & 1 & - & - & 1 & - \\
1827 & 38 & 36 & 2 & - & - & - & - \\
1828 & 44 & 41 & 1 & - & - & 2 & - \\
1829 & 48 & 47 & 1 & - & - & - & - \\
1830 & 34 & 32 & 1 & - & - & 1 & - \\
1831 & 41 & 40 & 1 & - & - & - & - \\
1832 & 28 & 27 & 1 & - & - & - & - \\
1833 & 25 & 24 & - & - & - & 1 & - \\
1834 & 24 & 22 & - & - & - & 2 & - \\
1835 & 23 & 23 & - & - & - & - & - \\
1836 & 33 & 29 & - & - & - & 4 & - \\
1837 & 34 & 30 & - & - & - & 2 & 2 \\
1838 & 26 & 25 & - & - & - & 1 & - \\
1839 & 29 & 27 & - & - & - & 1 & 1 \\
1840 & 22 & 22 & - & - & - & - & - \\
1841 & 26 & 24 & - & - & - & 1 & 1 \\
1842 & 20 & 20 & - & - & - & - & - \\
1843 & 25 & 24 & - & - & - & - & 1 \\
1844 & 23 & 23 & - & - & - & - & - \\
1845 & 21 & 21 & - & - & - & - & - \\
1846 & 32 & 31 & - & - & - & 1 & - \\
1847 & 32 & 31 & - & - & - & 1 & - \\
1848 & 27 & 26 & - & - & - & - & 1 \\
1849 & 24 & 1 & - & - & - & 2 & 1 \\
1850 & 21 & 21 & - & - & - & - & - \\
1851 & 15 & 15 & - & - & - & - & - \\
\hline Összesen: & 4148 & 1950 & 347 & 108 & 45 & 1457 & 241 \\
\hline & & & & & & & \\
\hline
\end{tabular}




\section{4. számú táblázat}

A diákok származási hely szerinti megoszlása (évtizedenként)

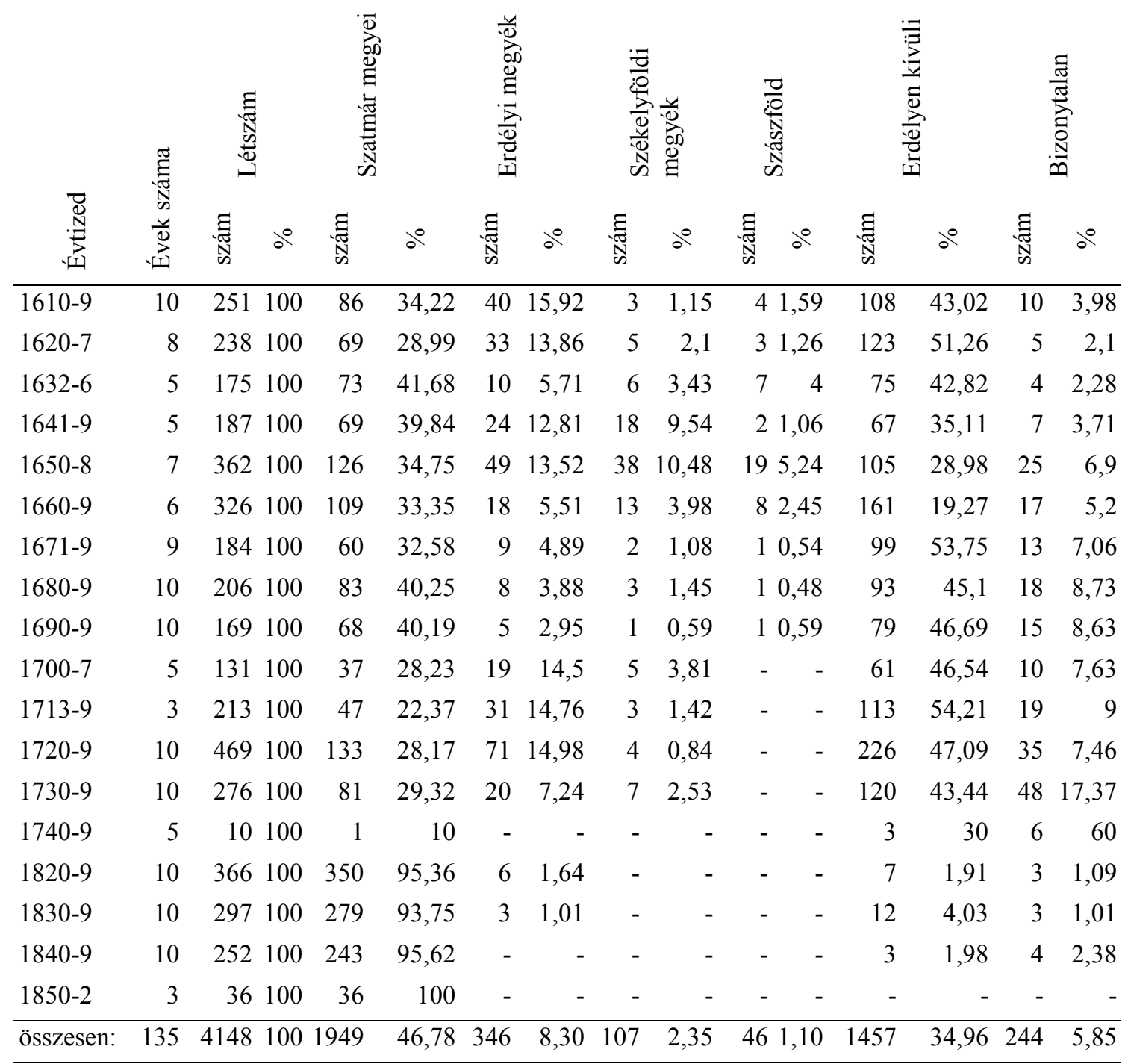




\section{5. számú táblázat}

A Szatmár városi és a Szatmár megyei tanulók megoszlása 1820-1852 közt

\begin{tabular}{|c|c|c|c|c|c|}
\hline \multirow[t]{2}{*}{ Év } & \multirow[t]{2}{*}{ Létszám } & \multicolumn{4}{|c|}{ Származási helyük } \\
\hline & & Szatmárnémeti & $\%$-ban & Szatmár megye & $\%$-ban \\
\hline 1820 & 35 & 23 & 65,71 & 12 & 34,29 \\
\hline 1821 & 33 & 21 & 63,63 & 11 & 33,33 \\
\hline 1822 & 36 & 20 & 55,55 & 14 & 38,88 \\
\hline 1823 & 27 & 10 & 37,03 & 17 & 62,97 \\
\hline 1824 & 37 & 12 & 32,43 & 23 & 62,16 \\
\hline 1825 & 34 & 12 & 35,29 & 21 & 61,76 \\
\hline 1826 & 34 & 9 & 26,46 & 23 & 67,64 \\
\hline 1827 & 38 & 12 & 31,57 & 24 & 63,15 \\
\hline 1828 & 44 & 15 & 34,09 & 26 & 59,09 \\
\hline 1829 & 48 & 19 & 39,58 & 26 & 54,16 \\
\hline 1830 & 34 & 17 & 49,99 & 15 & 41,11 \\
\hline 1831 & 41 & 20 & 48,78 & 20 & 48,78 \\
\hline 1832 & 28 & 16 & 57,14 & 11 & 39,28 \\
\hline 1833 & 25 & 12 & 48,00 & 12 & 48,00 \\
\hline 1834 & 24 & 11 & 45,83 & 11 & 45,83 \\
\hline 1835 & 23 & 11 & 47,82 & 12 & 52,18 \\
\hline 1836 & 33 & 16 & 48,48 & 13 & 39,39 \\
\hline 1837 & 34 & 13 & 38,23 & 17 & 50,00 \\
\hline 1838 & 26 & 15 & 57,69 & 10 & 38,46 \\
\hline 1839 & 29 & 13 & 44,82 & 14 & 48,27 \\
\hline 1840 & 22 & 9 & 40,90 & 13 & 50,10 \\
\hline 1841 & 26 & 14 & 53,84 & 10 & 38,46 \\
\hline 1842 & 20 & 13 & 65,00 & 7 & 35,00 \\
\hline 1843 & 25 & 15 & 60,00 & 9 & 36,00 \\
\hline 1844 & 23 & 16 & 69,56 & 7 & 30,44 \\
\hline 1845 & 21 & 14 & 66,66 & 7 & 33,34 \\
\hline 1846 & 32 & 21 & 65,62 & 10 & 31,25 \\
\hline 1847 & 32 & 19 & 59,37 & 12 & 37,50 \\
\hline 1848 & 27 & 15 & 55,55 & 11 & 40,74 \\
\hline 1849 & 24 & 8 & 33,32 & 13 & 54,16 \\
\hline 1850 & 21 & 11 & 52,37 & 10 & 47,63 \\
\hline 1851 & 15 & 8 & 52,33 & 7 & 46,67 \\
\hline \multicolumn{2}{|c|}{ Összesen: 951} & 460 & 48,37 & 448 & 47,10 \\
\hline
\end{tabular}

A táblázatok tanúsága szerint a szatmári református kollégium diákságának közel 47 százaléka Szatmár megyei származású volt. A Szatmár-vidékiek részaránya azonban koronként változó. A XVII. században és a XVIII. század első évtizedeiben a kollégium diákságának mintegy 32 százaléka volt Szatmár megyei származású. Ez a részarány néhány évtizedben - A XVII. század harmincas-negyvenes éveiben, valamint a nyolcvanas-kilencvenes években - az átlagosnál jóval magasabb volt, a XVIII. században viszont 27 százalékra csökkent. 18201852 közt az iskolába beírt felső osztályosok több mint 95 százaléka volt Szatmár megyei, közülük is több volt a Szatmárnémetiből származó (48,37\%), kevesebb a megye más helységeibe való $(47,1 \%)$. 
Az erdélyi megyékböl összesen 347 diák (8,32\%) tanult a kollégiumban. A kollégium történetének első korszakában, tehát 1610-1747 között a kollégium diákságának átlag 10-11 százalékát alkották erdélyi diákok. Számuk tíz vagy ennél nagyobb 1621-ben, 1652-ben, 1654-ben és 1658-ban volt, illetőleg a szatmári békekötést követő években, 1714-ben, 1719ben, 1723-ban, 1724-ben, 1729-ben és 1737-ben.

Az 1820-1830-as években összesen 9 erdélyi származású diák tanult a kollégiumban (0,21\%); számuk az adott kor diákságának alig 1-1,5 százaléka.

Az erdélyi megyék közül általában a szomszédosak adtak több diákot Szatmárnak: KözépSzolnok 107-et, Kraszna 41-et, Belső-Szolnok 25-öt; sokan jöttek a távolabbi Alsó-Fehér (29) és Küküllő (23) megyéből is.

A kollégiumban székely diákok csak a XVII-XVIII. században tanultak, összesen 108-an (2,59\%). Ez a szám az iskola első korszaka diáklétszámának 3,32 százaléka. A székely diákok száma 1640-1660 közt jelentősebb (8-9\%), más évtizedekben (általában) csak 1-2 százalék.

A székely székek közül Háromszék településeiröl érkezett a legtöbb diák a szatmári kollégiumba, 83 tanuló (1,99\%), a székely diákok háromnegyede.

A Szászföld településeiről 45 diák (1,08\%) tanult a szatmári kollégiumban, valamennyi a XVII. században. A legtöbben Szebenszékből (19 diák) és Brassó-vidékéről (12 diák) jöttek.

A szász diákok az aláírási jegyzőkönyvbe mindig teljes német nevüket írták be, mellette jelölték nemzetiségüket vagy származási helyüket is: saxo, Cibiniensis. Így megállapíthatjuk, hogy a kollégiumban összesen 15 szász diák (0,36\%) tanult. A többi szászföldi diák az ottani magyar településekröl származott.

Görögkeleti és görög katolikus diák, következésképp román és ukrán nemzetiségü tanuló református kollégiumban a Türelmi Rendelet (1781) megjelenéséig nem tanulhatott, ilyeneket tehát a szatmári református kollégiumban sem találunk.

A fent tárgyaltakon kívül a többi nem erdélyi megyéböl való a kollégiumban tanult diákok 34,96 százaléka. Számuk különösen a XVII-XVIII. században jelentős. Ezekböl, valamint a törökök által megszállt területekről származók alkották ekkor a kollégium diákságának legalább 45 százalékát. A XVII-XVIII. századbeli diákságból 1433 e területekre való diák származási helyét valószerüsítettük (34,39\%), s még mintegy 129 diákról (2,92\%) bizonyosnak tekinthető, hogy a nem erdélyi területekröl való, de - a már említett okok miatt eldönthetetlen -, hogy az azonos nevü helységek melyikéről is van szó.

Az Erdélyen kívüli területekröl származott a XVII-XVIII. században 1254 tanuló (az akkori diákság 38,87\%-a), a török hódoltságból pedig 179 diák (5,55\%).

Amelyik faluba egyszer bevette magát a tanulás szokása, ott az iskolázottak számos fiatalabb családtagjukat és más falubelijüket vonták maguk után a kollégiumba. ${ }^{91}$ A tanulás szokása mértékének szemléltetésére összeállítottuk azoknak a helységeknek a jegyzékét, amelyekből 1610-1747 és 1820-1852 közt tízen vagy ennél többen tanultak a szatmári református kollégiumban. Ezek a következők:

10: Bereg, Cégény, (Szamos)Dob, Fancsika, Gencs, Kisvárda, Kölcse, Losonc, Makód, (Kis-, Nagy) Peleske, Récse, Szaniszló, Szentgyörgy, (Máramaros)Sziget, Tárkány, Vaja, Veresmart, Zsadány

\footnotetext{
91 Jakó: i.m. 63.
} 
11: Gyügye, Léva, (Nagy)Muzsaly, (Kis)Namény, Sára, Veszprém

12: Angyalos, Bökény, Fülesd, (Sándor)Homok, Kecskemét, Nagybánya, Szeben, Tarpa, Tasnád, (Komlód)Tótfalu, Ura, Vác

13: Csegöld, (Puszta)Daróc, Krassó, Szárazberek, (Kis-, Nagy)Majtény

14: (Aranyos-, Nyír)Meggyes, Sárköz, Ungvár

15: Huszt, Nagyar, (Kis-, Nagy)Szekeres, Szenc, Tass, Udvari, (Hernád)Vécse

16: Borosjenő, Bökény, Gacsály, (Kántor)Jánosi, (Kraszna)Horvát, Patak, (Nagy) Szőllős, Rápolt, Técső, Zsarolyán

17: (Kis-, Nyír)Bátor, Cegléd, Cseke, Kisar, Matolcs, Szentpéter

18: Batiz, (Felső-, Kapnik-, Nagy)Bánya, (Nagy)Kálló, Sályi, (Bereg-, Nagy-, Tisza) Szőllős

19: Erdőd, Jánk, Rozsály

21: Tunyog, (Szinér)Váralja

23: Lázári, Óvári, Porcsalma, Újlak

25: Császló, (Ér)Szentkirály

26: (Avas)Újváros, Vetés

29: Várad

30: Porcsalma

32: Almás

34: Visk

37: Debrecen

38: (Nagy)Károly

39: Beregszász

43: Mikola

54: (Fehér)Gyarmat

56: Csenger

58: Vári

149: Németi

493: Szatmár

A kollégium anyakönyveiből ismert 4148 tanuló jelentős többségének, 3903 diáknak $(93,67 \%)$ ismerjük tehát a származási helyét, 68 diákról $(1,63 \%)$ pedig tudjuk azt, hogy melyik tájegységröl jött a kollégiumba.

A Matricula studiosorumban szereplő 2845 tógás diák és 274, az iskolaszéki jegyzőkönyvekben megemlített, tehát összesen 3119 diák származáshelyét illetően sikerült meghatározni a helységet, amelyikből a diák származik. Ebből az időszakból való az a 68 diák is, akinek esetében csak a nagyobb tájegységet tudtuk valószerüsíteni.

A XIX. századi anyakönyvben szereplő 951 diák közül mindössze tíznek nem ismerjük a származási helyét. 
A pontosan meghatározott származási helyü diákok megoszlását az 1848 előtti közigazgatási beosztás szerint közöljük, a helység neve után következő számmal jelölve, hogy az illető helységböl hányan tanultak a szatmári református kollégiumban.

Szatmár megyéből 1950 olyan diák tanult a kollégiumban, akiknek a származási helye pontosan ismeretes, közülük 743 a XVII., 299 a XVIII. és 908 a XIX. század első felében tanult az iskolában. Ezek a tanulók a következő helységekből jöttek a kollégiumba:

Szatmár megyéből a következő elosztásban tanultak a kollégiumban: Adorján 8, Angyalos 12, Apa 1, (Dobrács)Apáti 8, (Mező)Aranyos 4, Aranyosmeggyes 10, (Kis-, Nagy)Ar 4, Atya 7, (Csenger)Bagos 5, (Felső-, Kapnik-, Nagy)Bánya 18, Batiz 18, (Kraszna)Béltek 5, Bere 1, Borzova 6, Börvely 2, Cégény 10, Csaholc 5, Csanálos 1, Császló 25, Csegöld 13, Cseke 17, Csenger 56, Csomaköz 2, (Cégény)Dányád 7, (Szamos)Dara 1, (Fülpös)Daróc 1, (Puszta)Daróc 13, (Fülpös-, Király-, Puszta)Daróc 9, Dengeleg 2, (Nyír)Derzs 3, (Szamos)Dob 10, Domahida 9, (Nagy)Ecsed 17, Egri 9, (Ér)Endréd 5, Erdőd 19, Erdőszáda 2, Fábiánháza 1, Fehérgyarmat 54, Felsőbánya 9, Fülesd 12, Gacsály 16, Garbolc 6, Gebe 1, Géberjén 2, Gencs 10, Géres 3, Gilvács 2, Görbed 2, Gyügye 11, Hermánszeg 5, Hirip 5, Hodász 1, (Nagy)Hodos 3, (Sándor)Homok 12, Iklód 1, Iriny 1, Istvándi 5, Jánk 19, (Kántor)Jánosi 16, Jármi 4, Kálmánd 4, (Nagy)Károly 38, Kér 1, Királydaróc 2, Kisar 17, Kiskolcs 3, Kisnamény 4, Kisszekeres 5, Kocsord 1, (Szamos)Kóród 4, Kökényesd 8, Kölcse 10, Kömörő 2, (Szamos)Krassó 13, Lázári 23, Lippó 2, (Kis-, Nagy)Majtény 13, Majtis 1, Mánd 8, Matolcs 17, (Aranyos-, Nyír)Meggyes 14, Mikola 43, Milota 1, Misztótfalu 2, Nábrád 7, Nagyar 15, Nagybánya 12, Nagydobos 3, Nagykolcs 1, Nagyszekeres 1, (Kis)Namény 11, Németi 149, Olcsva 1, Ombód 2, (Vámos)Oroszi 7, Óvári 23, Ököritó 9, (Bot-, Kis-, Nagy)Palád 8, (Ó)Pályi 8, Panyola 1, Patóháza 2, (Kis-, Nagy)Peleske 10, Penyige 6, Mezőpetri 2, Pettyén 9, Piskolt 2, Porcsalma 30, Rápolt 16, (Köszeg)Remete 4, Ricse 2, Rozsály 19, Sályi 18, Sár 1, Sárköz 14, Sárközújlak 1, (Csenger)Sima 2, Sonkád 2, Szakasz 2, (Máté)Szalka 3, Szamosszeg 1, Szaniszló 10, Szárazberek 13, Szatmár 483, Szatmárhegy 1, (Kis-, Nagy)Szekeres 15, Szentmárton 2, Szentmiklós 7, Szinérváralja 21, Tarpa 12, (Töke)Terebes 5, (Mezö)Terem 3, Tiszabecs 8, Tiszaberek 1, (Komlód)Tótfalu 12, Tunyog 21, Tyukod 9, Udvari 15, (Csenger)Újfalu 6, (Szamos)Újlak 25, (Avas)Újváros 26, Ura 12, Uszka 2, Vállaj 1, (Szamos)Veresmart 10, Vetés 26, Vezend 2, Zsadány 10, Zsarolyán 16. - Összesen 1950 diák $(46,80 \%)$.

A többi 1954 diák, akinek származási helyét ismerjük, a következő megyékből, illetőleg helységekből származik:

Abaúj vm.: Balogd 3, Buzinka 3, Eszkáros 1, Fony 2, Füzér 4, Gönc 11, Halmaj 1, Héce: Hejce 2, Ináncs 5, Kassa 3, Nagyida 2, Pere 1, Pólyi 3, Regmec 5, Rozgony 3, Selyeb 1, Somodi 4, Szepsi 5, Szikszó 8, Vizsoly 8. - Összesen: 75 diák (1,8\%).

Baranya vm.: Csuza 1, Eszék 3, Gyüd 1, Karancs 2, Kölked 2, Laskó 1, Liget 1, Mohács 4, Pécs 6, Sepse 1, Somogy 2. - Összesen: 24 diák (0,57\%).

Bars vm.: (Ó-, Új)Bars 2, Ény 1, Keresztúr 3, Kisszecse: Felsőszecse 2, Léva 11, Radóc 1, (Kis-, Nagy)Salló 8. - Összesen: 28 diák (0,67\%).

Békés vm.: Békés 3, Bélmegyer 2, Füzesgyarmat 2, Gyoma 1, Szeghalom 1. - Összesen: 9 diák $(0,22 \%)$.

Bereg vm.: (Kis-, Nagy)Bégány 1, Bene 1, Beregszász 39, (Bereg)Bükös 1, Csaroda 4, Csetfalva 5, (Kis-, Nagy)Dobrony 2, Fejércse 3, Gát 4, Gulács 8, Halábor 2, Ilosva 4, (Mező)Kászon 7, (Tisza)Kerecsen 1, (Kis-, Nagy)Lónya 1, Munkács 3, (Nagy)Muzsaly 11, Szombati 9, (Bereg)Szőllős 1, Tarpa 11, Vári 58. - Összesen: 176 diák (4,23\%). 
Belső-Szolnok vm.: Décse 3, Dés 4, Domokos 1, (Nagy)Mező 1, Ormány 1, Retteg 7, Szentbenedek 1, (Szamos)Újvár 6. - Összesen: 24 diák (0,57\%).

Bihar vm.: (Ér)Adony 1, Albis 3, Árkus 1, Bagamér 6, (Nagy)Bajom 3, Belényes 2, (Berettyó)Újfalu 2, Bihar 1, Bogyoszló 1, Bojt 1, Csatár 3, Csokaly 1, (Bihar)Diószeg 8, Fegyvernek 1, Harsány 1, Illye 2, (Kis)Kereki 1, Kismarja 4, Kistóti 1, Konyár 2, Kölesér 1, Körösszeg 1, (Nagy)Léta 1, Margitta 4, (Ér)Mihályfalva 7, Ottomány 1, Szalacs 8, (Nagy)Szalonta 4, Székelyhid 1, Szentandrás 1, Szentelek 2, Szentimre 6, Széplak 3, Tárkány 14, Telegd 1, Várad 29. - Összesen: 130 diák (3,12\%).

Borsod vm.: Bessenyő 3, Diósgyőr 1, (Sajó)Galgóc 2, Fejéregyháza 1, Galvács 1, (Tisza)Kezi 1, Miskolc 8, Ónod 2, Szederkény 4, Szendrő 3. - Összesen: 26 diák (0,62\%).

Csanád vm.: Csanád 1, Makó 7, (Hódmező)Vásárhely 4. - Összesen: 12 diák (0,29\%).

Csongrád vm.: Szeged 9, Szentes 1, (Tisza)Földvári 1. - Összesen: 11 diák (0,26\%).

Doboka vm.: Göc 2, Kenes 1, Sárvár 2, Szék 2, Veresegyháza 1. - Összesen: 8 diák (0,19\%).

Esztergom vm.: Esztergom 1. - Összesen: 1 diák (0,02\%).

Fehér vm.: Alvinc 5, Gyulafehérvár 7, (Nagy)Enyed 6, Kutyfalva 1, Martonfalva 1, Meggykerék 4, Sorostély 1, Tür 1, Vajasd 4. - Összesen: 30 diák (0,72\%).

Fejér vm.: Csut 1, Füle 1, Mány 4, Pákozd 3, Polgárdi 1, Székesfehérvár 1, Tácz 2. Összesen: 13 diák $(0,31 \%)$.

Gömör vm.: (Alsó-, Felső)Balog 1, (Alsó)Bátka 1, Gömörnánás 2, Hamva 5, Harmac 6, Kisfalu 1, Kövi 1, Páskaháza 1, Pást 1, Pelsőc 1, Rimaszombat 3, Szkáros 3. - Összesen: 26 diák $(0,62 \%)$.

Győr vm.: Győr 1. - Összesen: 1 diák (0,02\%)

Hajdú kerület: (Hajdú)Böszörmény 8, (Tisza)Csege 1, Debrecen 37, Nánás 7, (Hajdú)Szoboszló 3, Téglás 6, (Balmaz)Újváros 1, (Vámos)Pércs 1. - Összesen: 64 diák (1,54\%).

Háromszék: (Közép-, Nagy-, Száraz)Ajta 9, Aldoboly 3, Almás 5, Árkos 4, Barót 1, Bita 1, (Sepsi)Bodok 3, Bodola 7, (Kis)Borosnyó 5, (Alsó-, Felső)Csernáton 2, Dálnok 4, Gidófalva 2, Hidvég 2, Illyefalva 2, Kézdivásárhely 2, Köpec 1, Lécfalva 2, Maksa 2, Nagyajta 1, Oltszem 1, Papolc 3, Páva 2, Réty 4, Torja 6, Uzon 2, Zabola 2, Zágon 3, Zalán 2. - Összesen: 83 diák $(1,99 \%)$.

Heves vm.: (Kis)Bátor 1, Csász 5, Felnémet 1, Gyöngyös 4, Maklár 2, (Tarna-, Tisza)Örs 2, Pásztó 2, Poroszló 5, Ugra 3. - Összesen: 25 diák (0,60\%).

Hont vm.: Bagonya 1, (Egyház)Marót 1. - Összesen: 2 diák (0,05\%).

Hunyad vm.: Cserna 1, Déva 3, Kéménd 1. - Összesen: 5 diák (0,12\%).

Jászság: (Tisza)Bura 1, Mesterszállás 1. - Összesen: 2 diák (0,05\%).

Kiskun kerület: (Kiskun)Halas 4, Szabadszállás 3. - Összesen: 7 diák (0,17\%).

Kolozs vm.: Drág 3, Gyalu 1, Hunyad 1, Kolozsvár 3, Komlód 1, Mócs 4, (Magyar)Nádas 1, Nyires 2, Zentelke 1. - Összesen: 17 diák (0,41\%).

Komárom vm.: Csúz 4, (Kis-, Nagy)Igmánd 1, Kolta 3, Komárom 9, Neszmély 2, Páth 1, Szomód 2, (Ó)Szőny 4, Tata 6, Udvard 2. - Összesen: 34 diák (0,82\%).

Körös vm.: Körös 3. - Összesen: 3 diák (0,07\%). 
Közép-Szolnok vm.: Ákos 8, Alszeg 1, Ardó 7, Baksa 3, Bősháza 1, (Szilágy)Cseh 5, (Magyar)Décse 2, Dobra 5, Hadad 6, Krasznacégény 1, Lele 1, Menyő 2, (Ér)Mindszent 1, Monó 1, (Magyar)Nádasd 1, Nagyszeg 3, Pér 3, (Tasnád)Szántó 2, (Tasnád)Szarvad 1, (Ér)Szentkirály 25, Sziget 2, Tasnád 12, (Szamos)Udvarhely 7, (Szamos)Újlak 1, Zilah 5, Zsibó 1. - Összesen: 107 diák (2,57\%).

Kraszna vm.: (Kraszna)Horvát 16, Kémer 9, Ráton 4, Récse 10, Varsolc 2. - Összesen: 41 diák $(0,98 \%)$.

Küküllő vm.: Apátfalva 1, Halmágy 5, Jövedics 1, Királyfalva 2, Kiskond 1, Kóród 4, Küküllővár 1, Miklóstelke 1, Radnót 2, Szentpál 1, Szépmező 4. - Összesen: 23 diák (0,55\%).

Külső-Szolnok vm.: (Mező)Tur 6, Szolnok 1. - Összesen: 7 diák (0,50\%).

Máramaros vm.: Bogdány 1, Hosszúmező 4, Huszt 15, Jablonca 3, Jód 1, Lipcse 3, (Máramaros)Sziget 10, Técső 16, Vajnág 3, Visk 34. - Összesen: 90 diák (2,16\%).

Marosszék: Fintaháza 1, Galambod 1, Kibéd 1, (Mező)Madaras 4, Makfalva 5, Marosvásárhely 1. - Összesen: 13 diák (0,31\%).

Nógrád vm.: Balassagyarmat 2, Fülek 1, (Nagy)Géc 1, Gergelyfalva 1, Kosd 5, Losonc 10, Lőrinci 3, Nógrád 4, (Sáros)Patak 16, Szécsény 1, Veres 2, Verőce 1, Veselény 1. - Összesen: 48 diák $(1,15 \%)$.

Nyitra vm.: Érsekújvár 1, Geszte 1, Péterfalu 4, Ság 2, Sasvár 1, Sellye 1, Sempte 5, Szécs 2, Szentmihályúr 1, Szolcsány 1, šrmény 1, Visnyó 2. - Összesen: 22 diák (0,53\%).

Pest vm.: Apostag 2, Buda 1, Cegléd 14, Dömsöd 7, Gödelö 1, Hévíz 1, Kecskemét 12, Monor 1, (Alsó-, Kis)Némedi 1, Solt 1, Szentendre 2, Szeremle 2, Sződ 1, Vác 12. Összesen: 58 diák (1,39\%).

Pozsony vm.: Alistel 1, Csákány 2, Csataj 1, Csötörtök 2, Nagyszombat 2, (Alsó-, Felső)Nyárasd 2, Szempcz: Szenc 15. - Összesen: 25 diák (0,60\%).

Sáros vm.: Eperjes 2, Hámbor 1, Harság 1, Magas 4, Megye 2, Rabóc 4, (Kis-, Nagy)Sáros 1, Somos 1, (Kis-, Nagy)Vitéz 2. - Összesen: 18 diák (0,43\%).

Somogy vm.: Bara 1, Denna 2, Szentlászló 1, Path 3, Pata 2. - Összesen: 9 diák (0,22\%).

Szabolcs vm.: (Nyír)Ábrány 1, Apagy 2, Balkány 1, Bátor 19, Bereg 10, Bogát 2, (Nyír)Bogdány 1, (Tisza)Eszlár 1, Gyulaháza 2, Nagykálló 18, Kemencse 2, Kisvárda 10, (Püspök)Ladány 4, (Nyír)Lugos 1, (Nagy-, Nyír)Máda 4, Makód 10, Mándok 4, Mogyorós 2, Nádudvar 3, Nagyfalu 1, Nyíregyháza 6, Ör 7, Pap 2, Pazony 1, Petneháza 1, Polgár 1, Sáp 1, Sényő 1, Szentmihály 5, Tass 12, Vaja 10, (Kis-, Nagy)Zádor 3. - Összesen: 148 diák (3,55\%).

Szászföld: Apáca 2, Bogács 2, Csernátfalu 4, Doborka 4, Felmér 1, Kisselyk 1, Krizba 6, Moha 2, Nagydisznód 1, Nagyselyk 2, Omlás 1, Segesvár 2, Szászmeggyes 1, Szászváros 1, Szeben 13, Veresmart 3. - Összesen: 46 diák $(1,10 \%)$.

Temes vm.: Temesvár 2. - Összesen: 2 diák (0,05\%).

Tolna vm.: Decs 1, Máza 1, Paks 3. - Összesen: 5 diák (0,12\%).

Torda vm.: Berkes 1, (Kis)Görgény 2, (Alsó)Jára 1, Magyari 1, Torda 2. - Összesen: 7 diák $(0,17 \%)$.

Torna vm.: Hídvégardó 1. - Összesen: 1 diák (0,02\%).

Torontál vm.: Asztalos 1, Becse 1, Pána 1. - Összesen: 3 diák (0,07\%). 
Trencsén vm.: Trencsén 1. - Összesen: 1 diák $(0,02 \%)$.

Udvarhelyszék: (Székely)Dálya 1, (Kis-, Nagy)Galambfalva 2, (Székely)Keresztúr 2, Mátisfalva 3, Muzsna 1, Újszékely 2, Vágás 1. - Összesen: 12 diák (0,29\%).

Ugocsa vm.: (Fertős)Almás 32, Bökény 16, Csedreg 4, Csepe 3, Csoma 4, Dabolc 2, Fancsika 10, Farkasfalva 5, Gyula 5, Halmi 4, Kökényesd 8, Nagyszőllős 16, Péterfalva 1, Salánk 7, Sasvár 7, Szászfalu 3, Szirma 2, Tekeháza 6, Tivadar 2, (Tisza)Újhely 6. - Összesen: 143 diák $(3,44 \%)$.

Ung vm.: Baranya 5, Csap 1, Csicser 3, Helmec 4, (Kis-, Nagy)Kapos 2, Nevicke 1, (Ung)Nyarád 1, Solymos 1, Szenna 1, Szerednye 3, Szobránc 3, Tiba 1, Ungpéteri 1, Ungvár 14, Zahar 2. - Összesen: 42 diák (1,01\%).

Vas vm.: Dávidháza 4, (Hidas)Hollós 1, Ispánk 2, Karakó 1, Körmend 8, Kőszeg 3, Muraszombat 1. - Összesen: 20 diák (0,48\%).

Veszprém vm.: Devecser 2, Doba 4, Enying 1, Gyimót 1, Lepsény 2, Pápa 3, Veszprém 11. Összesen: 24 diák $(0,58 \%)$.

Zala vm.: Páka 1, Vince 1. - Összesen: 2 diák (0,05\%).

Zaránd vm.: Erdőhegy 2, (Boros)Jenő 15, Vadász 3. - Összesen: 20 diák (0,48\%).

Zemplén vm.: Abara 2, Borsi 5, Gercsely 1, Gesztely 6, (Király)Helmec 2, Kraszna 3, Karcsa 1, Kozma 1, Lask 1, Legenye 4, Luc 1, Mád 4, Megyaszó 3, Mislye 1, Modra 1, (Hernád)Németi 1, (Kis-, Nagy)Ráska 8, (Kis-, Nagy)Ruszka 2, Sára 9, Sztára 1, Szőlőske 7, Tarcal 7, Tokaj 9, (Kis-, Nagy)Toronya 1, Varannó 2, Vécse 12, Vitány 2, Zemplén 1. - Összesen: 98 diák $(2,35 \%)$.

Zólyom vm.: Mátyásfalva 1, Pónik 1, Zólyom 1. - Összesen: 3 diák (0,07\%).

A tájegységet jelölő nevek alapján Szatmár vagy Bereg megyeinek kell tartanunk a két Szamosközi nevü diákot, Erdélyből valónak az Erdélyi (7), Transilvanus (4), Kraszna, KözépSzolnok esetleg Szatmár megyeinek ${ }^{92}$ a Szilágyi (42), Székelyföldre valónak a Baconi (1), Kovásznai (2) nevüeket. Tokajhegyaljára való a Submontanus (1), a Dunántúlra valószínüleg Zala megyébe - a Muraközi (1).

Csak megyéket megjelölő nevek: Árvai (1), Liptói (1), Szerémi (4), Turóci (2).

A XIX. századi beírási anyakönyv adatai alapján pontosan ismerjük az 1820-1855 között az alsóbb osztályokba járt tanulók származási helyét is. Közülük $2405(68,46 \%)$ a Szatmárnémetiből, 1056 (29,99\%) a megye különböző helységeiből származó, s csak 54 (1,55\%) a más megyebeli diák.

Az egyes osztályok diákjainak származási helyét a 6-os számú táblázatban mutatjuk be:

92 A Szilágyi elnevezésen vidéket kell érteni, ugyanis a Szilágyság nem azonos teljes egészében Kraszna és Közép-Szolnok vármegyékkel. A Szilágy vidéke... kiterjedt Szatmár vármegyének egyes részeire is, s egyszer nagyobb, másszor kisebb területet jelöltek Szilágy névvel. Vö.: Petri Mór: Szilágy vármegye monographiája. I-VI. Budapest 1901-1904. I. 91-92. 
6. számú táblázat Az alsóbb osztályok tanulóinak létszáma és származási helye
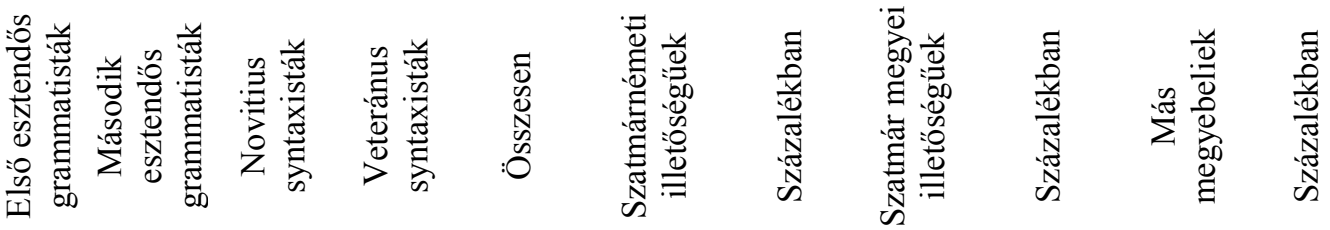

\begin{tabular}{|c|c|c|c|c|c|c|c|c|c|c|c|}
\hline 1820 & 25 & 25 & 24 & 18 & 92 & 58 & 63,04 & 33 & 35,64 & 1 & 1,08 \\
\hline 1821 & 42 & 31 & 21 & 27 & 121 & 80 & 66,13 & 41 & 33,87 & & \\
\hline 1822 & 39 & 47 & 25 & 25 & 136 & 86 & 63,23 & 50 & 36,77 & & \\
\hline 1823 & 52 & 40 & 34 & 30 & 156 & 101 & 64,74 & 55 & 35,26 & & \\
\hline 1824 & 53 & 48 & 29 & 33 & 163 & 98 & 60,13 & 63 & 38,63 & 2 & 1,24 \\
\hline 1825 & 90 & 60 & 45 & 36 & 171 & 114 & 66,66 & 57 & 33,34 & & \\
\hline 1826 & 33 & 33 & 39 & 34 & 139 & 111 & 79,86 & 28 & 20,14 & & \\
\hline 1827 & 38 & 27 & 24 & 44 & 153 & 139 & 90,85 & 12 & 7,85 & 2 & 1,3 \\
\hline 1828 & 45 & 30 & 26 & 31 & 132 & 100 & 75,76 & 30 & 22,73 & 2 & 1,51 \\
\hline 1829 & 43 & 29 & 26 & 20 & 118 & 98 & 83,06 & 20 & 16,94 & & \\
\hline 1830 & 50 & 37 & 28 & 29 & 144 & 118 & 81,94 & 25 & 17,35 & 1 & 0,71 \\
\hline 1831 & 29 & 42 & 32 & 25 & 128 & 109 & 85,16 & 17 & 13,28 & 2 & 1,56 \\
\hline 1832 & 69 & 26 & 30 & 35 & 160 & 126 & 78,75 & 29 & 18,12 & 5 & 3,23 \\
\hline 1833 & 54 & 43 & 24 & 34 & 155 & 115 & 74,2 & 35 & 22,17 & 5 & 3,23 \\
\hline 1834 & 26 & 29 & 37 & 22 & 114 & 86 & 75,44 & 28 & 24,56 & & \\
\hline 1835 & 44 & 21 & 17 & 37 & 119 & 83 & 69,75 & 34 & 28,57 & 2 & 1,68 \\
\hline 1836 & 33 & 24 & 19 & 19 & 95 & 59 & 62,71 & 35 & 36,84 & 1 & 1,05 \\
\hline 1837 & 17 & 16 & 28 & 19 & 80 & 57 & 71,25 & 23 & 28,75 & & \\
\hline 1838 & 18 & 17 & 24 & 22 & 81 & 56 & 69,14 & 20 & 24,69 & 5 & 6,17 \\
\hline 1839 & 26 & 11 & 14 & 15 & 66 & 50 & 75,75 & 13 & 19,7 & 3 & 4,55 \\
\hline 1840 & 24 & 26 & 14 & 8 & 72 & 50 & 69,45 & 13 & 19,7 & 3 & 4,55 \\
\hline 1841 & & 9 & 25 & 12 & 46 & 30 & 65,22 & 16 & 34,78 & & \\
\hline 1842 & 29 & 33 & 10 & 17 & 89 & 64 & 71,99 & 24 & 26,89 & 1 & 1,12 \\
\hline 1843 & 33 & 18 & 32 & 11 & 94 & 63 & 67,02 & 29 & 30,82 & 2 & 2,16 \\
\hline 1844 & 28 & 21 & 24 & 11 & 84 & 47 & 55,96 & 33 & 39,28 & 4 & 4,76 \\
\hline 1845 & 26 & 21 & 21 & 25 & 93 & 53 & 57 & 38 & 40,85 & 2 & 2,15 \\
\hline 1846 & 26 & 17 & 23 & 18 & 84 & 39 & 46,45 & 43 & 51,17 & 2 & 2,38 \\
\hline 1847 & 29 & 18 & 14 & 16 & 77 & 41 & 53,26 & 36 & 46,74 & & \\
\hline 1848 & 11 & 12 & 11 & 10 & 44 & 29 & 65,92 & 14 & 31,81 & 1 & 2,27 \\
\hline 1849 & 9 & 7 & 7 & 10 & 33 & 18 & 54,55 & 13 & 39,39 & 2 & 6,06 \\
\hline 1850 & 23 & 9 & 9 & 5 & 46 & 20 & 43,49 & 23 & 49,99 & 3 & 6,52 \\
\hline 1851 & 16 & 15 & 9 & 10 & 50 & 20 & 40 & 30 & 60 & & \\
\hline 1852 & 21 & 15 & 12 & 9 & 57 & 28 & 49,13 & 29 & 50,87 & & \\
\hline 1853 & 21 & 13 & 14 & 9 & 57 & 29 & 50,88 & 28 & 49,12 & & \\
\hline 1854 & 29 & 19 & 10 & 8 & 66 & 30 & 45,45 & 33 & 50 & 3 & 4,54 \\
\hline \multicolumn{2}{|c|}{ Összesen: } & & & & 3515 & 2405 & 58,46 & 1056 & 29,99 & 54 & 1,55 \\
\hline
\end{tabular}




\section{A diákok továbbtanulása, pályaválasztása}

A testvérkollégiumok hagyományai Szatmáron is érvényesültek, a diákok az előző években a kollégiumban tanult társaik neve mellé megjegyzéseket írtak a Matricula studiosorumba, s bejegyezték diákelődeik életpályájára vonatkozó ismereteiket is.

Vegyük számba először azokat, akik nem fejezték be kollégiumi tanulmányaikat. A bejegyzések tanúsága szerint 39 diák $(0,14 \%)$ tanulmányai végzése közben meghalt. A matrikula utolsó részében - az időpontot nem jelölve - viszont 194 nevet említ. Ez - hat kéz írása utólagos számbavételnek tünik.

A tanulói létszám megfogyatkozásához a szigorú iskolai rendszabályzat is bizonyosan hozzájárult, némelyeket távozásra késztetett a tanulásban tanúsított hanyag magatartásuk is. Összesen 49 tanulóról jegyezték fel, hogy megszökött az iskolából. A diákközösség feltehetően elmarasztalta őket, ugyanis majdnem kivétel nélkül azt jegyezték be az eltávozottakról, hogy titokban megszökött, sokuknál még azt is odaírták, hogy dicstelenül, másoknál azt, hogy az akasztófáravaló.

Tíz tanulóról tudjuk, hogy elbocsátották - azaz csendesen eltávolították -, negyvenötöt kizártak, hetet pedig becstelenségben bocsátottak el - a kizárás legsúlyosabb módja volt ez -, vagyis a kollégiumból fegyelmi úton 1610-1747 között összesen 62 diákot távolítottak el.

Hat tanuló házasságot kötött, ezért távozott.

Az aláírási jegyzőkönyvek nem tájékoztatnak a vétségekről, amelyeknek következménye az erőszakos eltávolítás lett. Viszont az iskolaszék 1719-1747 közti fegyelmi üléseiröl tájékoztató jegyzőkönyvek két ilyen esetet is megörökítettek: Pályi János seniort részegség, garázdaság, a feljebbvalók iránti engedetlenség és a közvagyon elprédálása miatt csapták ki a kollégiumból, Debreczeni Jánost pedig az 1735 októberében hat hétig tartó diáklázadás megszervezéséért. A lázadásban az egész diákság részt vett, Németi Sámuel professzor magatartása és nevelöi hibái ellen lázadtak fel, de botokkal támadták meg a város polgárait is. A lázongók közül csak az a 18 maradhatott meg a kollégiumban, aki újból letette az engedelmesség esküjét, a többieket kiutasították. ${ }^{93}$

A Matricula studiosorum adataiból megállapítható, hogy a kollégium XVII-XVIII. századi korszakában a kollégiumnak a legtöbb kapcsolata a debreceni, a sárospataki, a kolozsvári és az enyedi kollégiummal volt. A szatmári diákok Debrecenben való továbbtanulása az egész ötnegyed századra jellemző, ez idő alatt a szatmári református kollégium 102 diákja tanult tovább a Debreceni Kollégiumban.

Gyulafehérváron 5, majd a Nagyenyedre költözött kollégiumban 14 diák tanult tovább, valamennyi a XVII. század második felében.

Sárospatakon is (32), Kolozsváron is (29) sokan folytatták tanulmányaikat, többen a XVII. század utolsó negyedében, java részük azonban a XVIII. század első harmadában.

Szórványosan más kollégiumokba (iskolákba) is eljutottak szatmári diákok, így Marosvásárhelyre (4), Kassára (2), Győrbe (1).

\footnotetext{
${ }^{93}$ Kovács: i.m. 15-20.
} 
A szatmári református kollégium 20 tanulójáról jegyezték fel, hogy akadémián tanult tovább. $^{94}$ A Matricula csak két tanuló esetében jelöli meg, hogy melyik egyetemen tanult, mindkettő Hollandiában, Franekerben. Eszéki Istvánról (1658) viszont csak azt közli, hogy Hollandiában tanult, s ott írta Prima veritas defensa címü könyvét.

Azok a tanulók, akik más kollégiumokba mentek tanulmányaikat folytatni, olykor mindjárt a következő (tan)évben, gyakorta azonban csak rövidebb-hosszabb megszakítás után iratkoztak be a másik kollégiumba. A megszakítások többnyire anyagi okokra vezethetők vissza. Ismeretes, hogy a XVII-XVIII. századi diákok továbbtanulásuk anyagi fedezetének biztosítása érdekében átmeneti időre, egy-két évre (falusi) tanítóságot, rektorságot vállaltak, s ezalatt megfelelö pénztartalékot gyüjtöttek. ${ }^{95}$

A Medgyesi A. András (1714) nevéhez bejegyzettekből például megtudjuk, hogy Szatmárról Kolozsvárra ment, onnan Görgénybe rektornak, majd Enyedre, onnét pedig Debrecenbe rektornak.

A diákok pályaválasztására vonatkozóan közel háromszáz bejegyzés található a matrikulában, ezek a diákság mintegy kilencedének életútjára utalnak.

A megjegyzések csupán 37 diák esetében jelölnek meg egyházi pályát (pastor, teológus), valószínü azonban, hogy jóval többen mentek egyházi pályára, viszont ezeket azok közt kell keresnünk, akik (többnyire teológiai) tanulmányaik folytatása végett Debrecenbe, Sárospatakra, Nagyenyedre mentek.

Bizonyos azonban, hogy a kollégium diákjainak (jelentős) többsége világi pályát választott. A XVIII. század közepének felekezeti villongásai idején a kollégium létét szükségtelennek tartók ezt a tényt használták fel ellene, azt állítván, hogy a tógátusok közül kevés lesz pap, legtöbben tanítókká válnak, akinek pedig ilyen állás sem jut, mesterember lesz vagy visszatér az eke szarvához.

A bejegyzések közt valóban számottevő a tanítói-nevelői pályára vonatkozó: 208 diák lett iskolai rektor, kilencen pedig főnemesi családoknál nevelők lettek.

A XVII. századi, de még a XVIII. század közepén müködő tanítókról meg kell mondanunk, hogy e korban őket is egyházi értelmiséginek tekintették. ${ }^{96}$

A tanulók neve mellé írt bejegyzések általában szűkszavúak. Az eddig említetteken kívül még 49 esetben megjelölik a helységet, ahová a diák szolgálatra hívatott, anélkül azonban, hogy megneveznék magát a szolgálatot. Ezek a diákok is valamennyien iskolai tanítómesterek vagy rektorok lettek. Egyértelmüen bizonyítják ezt a matrikulában megtalálható pénzügyi feljegyzések, amelyekből (a legtöbb esetben) pontosan megállapítható, hogy a falusi iskola éppen ezekért a tanítóvá lett tanulókért mekkora összeget fizetett a kollégium pénztárába a bursa sacra számára.

94 A következőkről: Stephanus Bathori 1649, Stephanus Eszéki 1657, Georgius Dányádi, Sámuel Wáradi, Johannes Bélteki, Michael Baxai, Johannes A. Szenczi 1675, Nicolaus éjvárosi 1684, Johannes Pataki, Michael Tatai, Stephanus Váári 1686, Georgius D. Győri 1687, Martinus S. Újvárasi, Nicolaus Újvárasi 1688, Johannes Pataki 1693, Sigismundus Deák, Georgius Árkosi 1713, Johannes Mogyorósi 1714, Stephanus Szentimrei 1729, Balthasar Kondor 1737.

Megjegyezzük: az évszámok azt jelzik, hogy a diákok mikor írták alá a jegyzőkönyvet, tehát (külföldi) akadémiákon csak későbbi időpontokban fordulhattak meg.

${ }^{95}$ Benkő: i.m. 98-100. és vö. Jakó Zsigmond nagyenyedi diáknévsoraival.

${ }^{96}$ Benkő: i.m. 90., Jakó i.m. 74. 
Összesen 266 tógás diákból lett tanító. Többségük falusi iskolában, 21-en városi iskolában. Rajtuk kívül még három diákból lett tanár, egy-egy diákból debreceni, illetőleg szatmári professzor, egyből pedig teológiai tanár.

A kollégium diákjaiból alakult a vidék világi értelmisége is, erre vonatkozóan azonban nagyon kevés az adatunk. Az 1700-as években négy diákról jegyezték fel, hogy „világi állapotba lépett", hétnek a neve mellé jegyezték be a politicus ${ }^{97}$ jelzőt; három diák jegyző lett.

Néhány diák kereskedői pályát választott, 1678-ból és 1713-ból van erre összesen három adatunk. Többen választottak még pontosabban meg nem határozható polgári pályát (civis factus est).

Katonai pályára öten léptek. Közülük három tiszti rangot kapott, brigadéros, zászlótartó, illetőleg tiszt lett. ${ }^{98}$

Ha a kollégium szellemének társadalmi és földrajzi hatósugarát kívánjuk vizsgálni, számba kell vennünk azokat a területeket, amelyekre egykori diákjai eljutottak, amelyeken müködtek, illetőleg azokat a rétegeket, amelyekkel az egykori diákok kapcsolatba kerültek.

Az erre vonatkozó adataink nagyon hiányosak, ezért következtetéseink nem általánosíthatók. A diákság közel kilenctized részének sorsáról nem tudunk. S bizonyára ezek a távolabbi területekre elkerült, illetőleg az oda visszatért diákok. Valamelyes képet mégis kaphatunk a kollégium hatósugaráról, ha számba vesszük azokat a helységeket, amelyekben a kollégium diákjai egy vagy több évre tanítóságot vállaltak, s munkásságukat kifejtették, illetőleg az időpontokat, amikor az illető helységbe kerültek. ${ }^{99}$

Az adatokból a következő kép alakul:

Szatmár megyébe a következő iskolákba mentek tanítónak a kollégium diákjai: ${ }^{100}$

Adorján (1658), Apa 1680, 1687, 1694, 1697, 1719, (1726), Béltek (1658), Cégény (1687, 1688, 1689), 1697, Cseke (1727), 1731, Csenger 1624, 1658, (1660), 1672 (ketten), (1673), 1678 (ketten), 1684, 1685, 1687, 1691 (ketten), 1694, 1719, (1727), 1729, 1733, Dara 1652, Daróc (1676), 1732, (Nagy)Ecsed 1697, Egri 1660, Endréd 1736, Erdőd 1654, (1671, 1678, 1687), 1734, Feketeardó 1673, Felsőbánya 1671 (ketten), 1678, Géberjén (1727), Gencs 1672, Géres (1728), (Fehér)Gyarmat 1657, 1658, 1679, 1683, 1684, 1687, (1688), 1690, 1697, 1719, (1726, 1727), 1732, 1734, Hirip 1660, Homok (1728), (Kántor)Jánosi (1623), 1678 (ketten), Jármi 1713, (Nagy)Károly (1676), 1678, 1680, 1683, 1684, (1689, 1691), 1694, 1697, 1707, 1714 (ketten), 1719, 1729, Királydaróc 1719, Kisszekeres 1686, Kolcs 1684, Kölcse (1685), 1686, 1729, Körtvélyes 1678, Krassó 1685, 1686, (Nagy)Majtény 1633, 1647, (1652), 1655, (1659, 1676, 1688), Matolcs 1694, 1697, 1707, 1719, 1724, (1727, 1728), 1732, (Aranyos)Meggyes 1676, (1676), 1686, 1688 (ketten), 1703, Mikola 1671, Milota (1726), Misztótfalu 1688 (ketten), 1697, Nábrád 1697, 1729, 1733, Nagyar 1689, Nagybánya 1688, Németi 1713, 1714, 1734, (1727), Óvári 1729 (ketten), Piskolt 1719, Porcsalma 1658, (1675),

\footnotetext{
${ }^{97}$ A politicus, secularis világi pályán működő személyre utaló megjegyzések. Vö. Jakó 1979. 74.

${ }^{98}$ A jegyzőkönyvek bejegyzései szerint Udvarhelyi Balázs (1610) brigadéros, Szőlősi András (1636) Thököly háborújában zászlótartó, Udvarhelyi István (1649) tiszt, (had)vezér lett.

${ }^{99}$ A helység neve utáni évszám a legtöbb esetben azt az évet jelöli, amelyben a tanítóvá lett diák nevét bejegyezték. Többször viszont - föként a XVIII. században - az évszám a tanítóság kezdetét jelöli.

${ }^{100}$ A zárójelbe tett évszámok az olyan tanítókat jelölik, akikről nem jegyezték be, hogy tanítói szolgálatra mentek, de ez a kollégiumi pénztár (Pecunia sacra) gazdasági bejegyzéseiből megállapítható.
} 
(Köszeg)Remete 1676, Sályi 1729, Sárköz 1685, 1687, 1714 (ketten), Sonkád 1671, (Máté)Szalka 1733, Szamosújlak (1728), Szaniszló 1686, 1694, 1697, (1726), Szatmár, Hóstát (suburbium) ${ }^{101}$ 1657, 1660, 1671, 1676 (ketten), 1678 (ketten), 1679; a kollégiumban: 1662, 1664 (hárman), 1680, 1686, 1703, 1713, Tunyog (1658), 1733, Udvari (1658), (Avas)Újváros (1671), 1678, (1685, 1686), 1686, 1687, 1688 (ketten), 1694 (ketten), 1697, (1728), Vámfalu 1672, 1678, 1680, 1684 (ketten), 1686, 1688 (ketten), 1707, (Szinér)Váralja 1671, (1684), 1686, (1690), 1728, Vetés 1656.

A kollégium diákjai más megyékbe a következő helységek iskoláiba kerültek tanítónak:

Abaúj vm.: Gönc 1688, Kassa 1688, Vécse 1713,

Alsó-Fehér vm.: Nagyenyed 1729,

Bereg vm.: Bereg 1686, Gulács 1658, 1686, Kászon 1682, 1684 (ketten), 1686, 1687, 1688, Munkács 1679, 1681, Muzsaly 1656, 1658, 1731, Miszti 1694, Tarpa (1680), 1688, 1694, (1697), 1731, Vári 1678, 1682, 1684 (ketten), 1686 (ketten), 1687 (ketten), (1688),

Bihar vm.: Margita 1649,

Hajdú kerület: Debrecen (1679), (1683), 1701,

Közép-Szolnok vm.: Tasnád (1673, 1675, 1676), Terem 1633,

Máramaros vm.: Dolha 1633, Hosszúmező (1675), 1694, 1697, Huszt 1735, (Mező)Kászony 1686, 1688, 1714, 1733, Técső 1675, (1676), 1678 (ketten), 1680, (1681, 1683), 1687, 1694, (1699), Visk (1672, 1676), 1678, 1679, 1681, (1682), 1684, (1685), 1686, 1688 (ketten), 1707 (ketten),

Marosszék: (Kis)Görgény 1713,

Nógrád vm.: Losonc 1678,

Pest vm.: Cegléd (1677),

Sáros vm.: Kende 1658,

Szabolcs vm.: Ör (1676), (Nagy)Máda 1633, 1675,

Ugocsa vm.: (Fekete)Ardó 1658 (ketten), Bökény (1676), 1694, 1703, 1719, Farkasfalva 1714, 1719, (Nagy)Szőllős (1671, 1675), 1678, 1680, (1684), 1686, Péterfalva (1726), Salánk (1660), 1671, 1672, Sásvár 1658, Tivadar 1684, Újhely 1671,

Ung vm.: Ungvár 1678.

Az adatokból következően mintegy 25 iskoláról állíthatjuk, hogy a kollégium hatósugarába tartozó olyan kisiskola volt, amely tanítót, rektort folyamatosan a kollégiumból kért. Ezek - az oda küldött tanítók számát is jelölve - a következők: Apa 6, Cégény 4, Csenger 18, Erdőd 5, (Fehér)Gyarmat 14, Hosszúmező 3, Károly 14, Kászon 4, Kölcse 3, Majtény 7, Meggyes 4, Matolcs 8, Nábrád 3, Németi 4, Nagyszőllős 6, Sárköz 4, Szaniszló 4, Szatmár: Hóstát 7, Tarpa 5, Técső 10, Újváros 12, Vámfalu 9, Vári 9, Váralja 5, Visk 12.

${ }^{101}$ Szatmár külvárosában, a Hóstátban 1642-ben létesült református elemi iskola, amikor a lakosság annyira megszaporodott, hogy külön egyházközséggé alakult. Az iskolát a szatmári református kollégium látta el tanítókkal. 1680-ban Apafi Mihály erdélyi hadai és a török csapatok teljesen elpusztították a Hóstátot, iskolája is megsemmisült. Vö.: Bakcsy: i.m. 11. és Borovszky: i.m. 210. 
Ezeknek az iskoláknak a tanulmányi rendjét a rektornak küldött diákok révén a szatmári kollégium szabta meg, illetőleg irányította, vagyis a szatmári anyaiskola partikulái voltak.

Földrajzi elhelyezkedésüket alábbi ábránk szemlélteti:

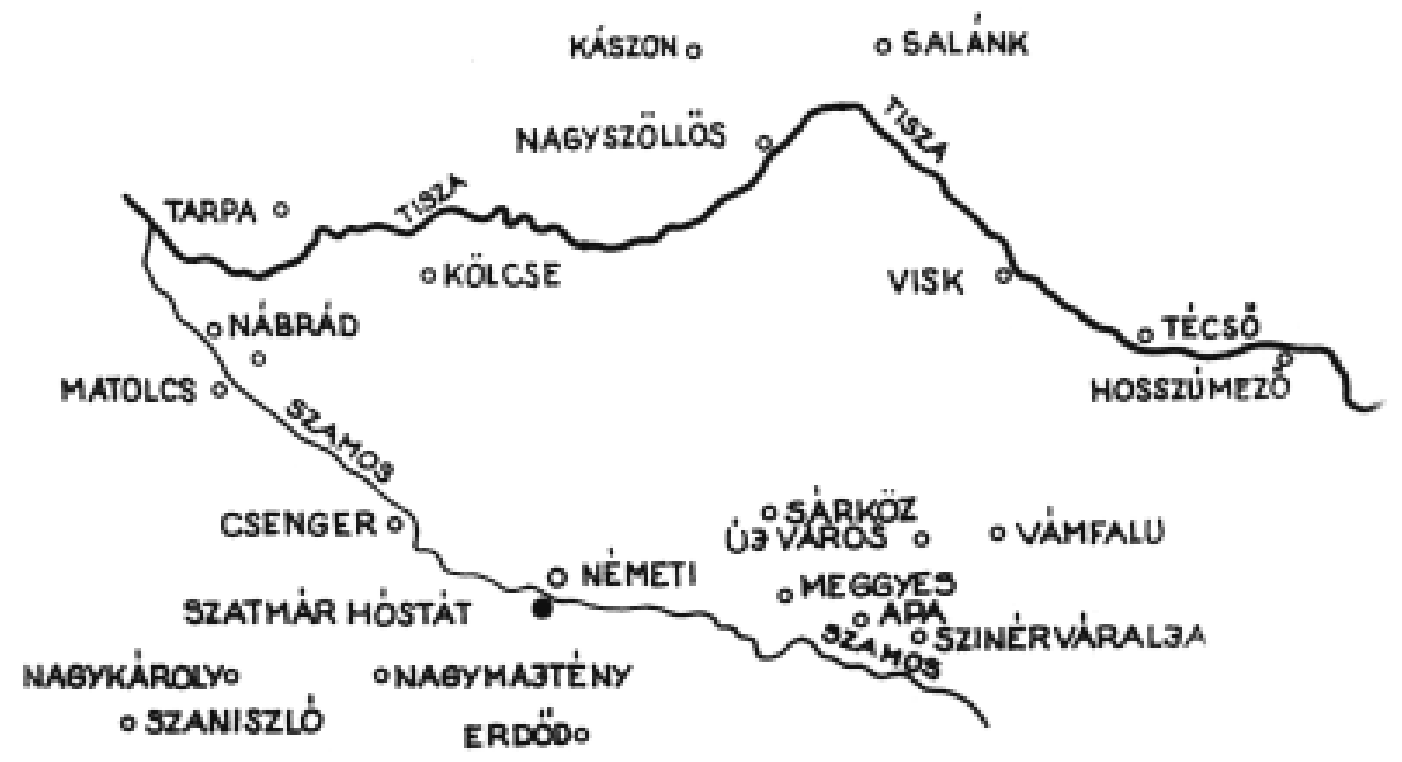

A szatmári iskola partikulái (ide küldték a rektorokat)

Tehát a kisebb városokban $\mathrm{s}$ a nagyobb falvakban is müködtek alsóbb fokú iskolák, a rendszeres falusi iskoláztatást azonban ebben az időben nem tudták megoldani, nem oldotta meg azt a református egyház sem. A tanítókkal ellátott iskolákat számba véve mégis azt kell megállapítanunk, hogy Szatmár megye iskolaügyi helyzete a XVIII. század hetvenes éveiben jónak mondható. Míg ugyanis 1770-1771. évi statisztikai felmérés adatai szerint a falvakban és királyi városokban müködő mintegy 4000 iskolából csak 2000-nek volt külön tanítója, a többiben a jegyző vagy a lelkész tanított. ${ }^{102}$ Az 1772 tavaszától 1773 szeptemberéig tartó széles körü összeírás pontos adatait rögzítő helytartótanácsi Lexicon szerint Szatmár megye 225 falujából 211-ben és mind a 19 mezővárosban volt tanító. A megye református felekezetü falvai közül 57-ben, valamint 8 mezővárosban müködött egy-egy, 33 faluban pedig két-két tanító. Minthogy - az előzőkben ismertetett adatok szerint - a szatmári református kollégium 56 helység iskoláiba bizonyosan küldött tanítókat, kultúraközvetítő szerepét számottevőnek kell mondanunk. ${ }^{103}$

A kollégium 1820-1852 közti diákságának közel 6 százaléka morzsolódott le: 4 meghalt, egyet kizártak, 11 elhagyta a kollégiumot, 13 pedig elszökött, vagyis titokban hagyta ott az iskolát.

Huszonhat diákról jegyezték fel, hogy inassá lett (gubás, csizmadia, gombkötő, tímár, takács, szabó, mészáros, borbély). Valószínünek kell tartanunk, hogy ezek a diákok megszakították kollégiumi tanulmányaikat s úgy kezdtek az iparosmesterség elsajátításához.

A kollégiumnak, mint említettük, a XIX. század első felében nem volt nyilvánossági joga, látogatottságát viszont magyarázza a tantestületnek az a törekvése, hogy a tanulókat az elismert iskolák szellemi szintjén tartsák. Eredményes munkájukat tanúsítja az a tény is, hogy

\footnotetext{
102 Mészáros 1981. 641.

${ }^{103}$ Uo. 641-646.
} 
más (elismert) iskolák átvették és a megfelelö osztályban tanították tovább a szatmári református kollégiumból átiratkozó tanulókat.

Azok a tanulók, akik hivatalosan is elismert tanulmányokkal kívántak rendelkezni, illetőleg a kollégiumban nem müködö bölcseleti osztályokat is el akarták végezni, tanulmányaikat a római katolikus Szatmári Püspöki Lyceumban ${ }^{104}$ (20 diák, 2,1\%), a Máramarosszigeti Líceumban (10 diák, 1,05\%) vagy a Debreceni Kollégiumban (38 diák, 3,99\%) folytatták.

Néhányan Sárospatakon (5), Eperjesen (3) tanultak tovább, egy-egy diák pedig Nagyenyeden, Nagykárolyban, Nagykállón, Hajdúböszörményben. Egy diákról csak annyit jegyeztek fel, hogy más iskolába ment.

Többen Késmárkra (4) és Lőcsére (3) mentek németül tanulni. Az anyakönyvbe a húszasnegyvenes években csak szórványosan jegyezték be egy-egy diák későbbi pályáját: rektor (tanító) lett 2 diák, prókátor 1, patikárius 1, professzor Szigeten 1, bányaőr, gazda (összesen) 3.

Feltételezhetjük, hogy a több mint 80 továbbtanuló diák különféle egyházi és világi pályákon helyezkedett el. A pályák megoszlásáról azonban közelebbit csak akkor tudhatnánk meg, ha a Szatmári Püspöki Lyceum, a Debreceni Kollégium, a Máramarosszigeti Líceum és a többi iskola anyakönyveinek diáknévsoraiban nyomon követhetnők az oda beiratkozott szatmári diákok útját.

\section{A diákság társadalmi összetétele}

Az 1610-1747 közötti szatmári diákság társadalmi eredet szerinti összetételéről bizonyítottan semmit sem mondhatunk; a Matricula studiosorum erre vonatkozó adatokat nem tartalmaz.

Összesen négy tanuló neve mellé jegyezték be azt, hogy nemes (nobilis), illetve hogy paraszt $^{105}$ származású. Néhány családról - melyekből mintegy harminc diák tanult a kollégiumban - Szatmár megye monográfiája alapján megállapítható, hogy birtokos nemesi származású. A többiek közt nemesi, értelmiségi, polgári származásúakat egyaránt feltételezhetünk. Ezeket az utóbbiakat főként a Szatmárról és Németiböl való diákok közt kell keresnünk. Pontos adataink vannak viszont az 1820-1852 közti diákság társadalmi eredet szerinti összetételéről. A felső tagozatos diákok társadalmi eredetét évenként és évtizedenként összesítve a 7-8. táblázaton mutatjuk be:

\footnotetext{
104 A Pázmány Péter által 1636-ban alapított jezsuita iskola 1786-ig működött a városban. Később 1807-ben négyosztályos gimnáziumként újrakezdi múködését, 1808-tól pedig már hatosztályos (4 grammatikai és 2 humán osztály).

A hat osztályt végzett ifjak filozófiai továbbképzésére 1804-ben alakult ugyancsak a szatmári római katolikus püspökség hatáskörében a kétosztályos Püspöki Líceum. A líceum a papi szeminárium keretében müködött, de világi tanulók is látogatták, függetlenül vallási hovatartozásuktól. Vö. Borovszky: i.m. 82.

${ }^{105}$ Pejoratív jelző is lehet.
} 
7. számú táblázat

A kollégiumban 1820-1852 közt tanult felső tagozatos diákok társadalmi összetétele

\begin{tabular}{|c|c|c|c|c|c|c|c|c|}
\hline Év & $\begin{array}{l}\text { Lét- } \\
\text { szám }\end{array}$ & $\begin{array}{l}\text { Birto- } \\
\text { kos }\end{array}$ & $\begin{array}{l}\text { Kis- } \\
\text { nemes }\end{array}$ & $\begin{array}{l}\text { Pol- } \\
\text { gár }\end{array}$ & Katona & $\begin{array}{l}\text { Értel- } \\
\text { miségi }\end{array}$ & $\begin{array}{l}\text { Föld- } \\
\text { müves }\end{array}$ & Egyéb \\
\hline 1820 & 35 & 3 & 5 & 16 & & 6 & 4 & 1 \\
\hline 1821 & 33 & 2 & 4 & 15 & & 7 & 3 & 2 \\
\hline 1822 & 36 & 7 & 3 & 14 & 1 & 8 & 1 & 2 \\
\hline 1823 & 27 & 7 & 3 & 8 & & 6 & 1 & 2 \\
\hline 1824 & 37 & 5 & 6 & 7 & & 13 & 2 & 4 \\
\hline 1825 & 34 & & 13 & 7 & 1 & 11 & 1 & 1 \\
\hline 1826 & 34 & & 13 & 8 & 1 & 10 & 2 & \\
\hline 1827 & 38 & & 13 & 14 & & 10 & 1 & \\
\hline 1828 & 44 & & 14 & 17 & & 12 & 1 & \\
\hline 1829 & 48 & & 12 & 13 & & 10 & 4 & 9 \\
\hline 1830 & 34 & & 9 & 13 & & 10 & 2 & \\
\hline 1831 & 41 & & 14 & 14 & & 10 & 2 & 1 \\
\hline 1832 & 28 & 1 & 8 & 12 & & 6 & 1 & \\
\hline 1833 & 25 & & 6 & 7 & & 11 & 1 & \\
\hline 1834 & 24 & 1 & 3 & 4 & & 11 & 1 & 4 \\
\hline 1835 & 23 & 1 & 3 & 3 & & 10 & 1 & 5 \\
\hline 1836 & 33 & & 16 & 6 & & 5 & 2 & 4 \\
\hline 1837 & 34 & & 15 & 6 & & 5 & 4 & 4 \\
\hline 1838 & 26 & & 12 & 4 & & 3 & 5 & 2 \\
\hline 1839 & 29 & & 13 & 7 & & 3 & 3 & 3 \\
\hline 1840 & 22 & & 12 & 6 & & 4 & & \\
\hline 1841 & 26 & & 15 & 7 & & 1 & 2 & 1 \\
\hline 1842 & 20 & & 12 & 6 & & 2 & & \\
\hline 1843 & 25 & & 14 & 9 & & & 1 & 1 \\
\hline 1844 & 23 & & 15 & 5 & & 1 & & 2 \\
\hline 1845 & 21 & & 13 & 4 & & 2 & & 2 \\
\hline 1846 & 32 & & 6 & 13 & & 7 & 1 & 5 \\
\hline 1847 & 32 & 1 & 2 & 9 & & 10 & 5 & 5 \\
\hline 1848 & 27 & 4 & & 10 & & 7 & 1 & 5 \\
\hline 1849 & 24 & 3 & 4 & 5 & & 4 & 3 & 5 \\
\hline 1850 & 21 & 2 & & 4 & & 6 & 7 & 2 \\
\hline 1851 & 15 & 3 & & 2 & & 3 & 5 & 2 \\
\hline \multicolumn{9}{|c|}{ Össze- } \\
\hline
\end{tabular}




\section{8. számú táblázat}

\section{A kollégiumban 1820-1852 közt tanult felső osztályos diákok társadalmi eredete évtizedenként}

\begin{tabular}{rrrrrrrrr}
\hline \multirow{2}{*}{ Évtized } & $\begin{array}{r}\text { Létszám } \\
\text { Százalék }\end{array}$ & Birtokos & Kisnemes & Polgár & Katona & Értelmiségi Földmüves & Egyéb \\
\hline \multirow{2}{*}{$1820-9$} & 366 & 34 & 86 & 119 & 3 & 93 & 20 & 21 \\
& $100 \%$ & 6,56 & 23,47 & 32,49 & 0,82 & 25,38 & 5,46 & 5,73 \\
\hline \multirow{2}{*}{$1830-9$} & 297 & 3 & 99 & 76 & & 74 & 22 & 23 \\
& $100 \%$ & 1,01 & 33,33 & 25,98 & & 24,91 & 7,43 & 7,74 \\
\hline \multirow{2}{*}{$1840-9$} & 252 & 8 & 93 & 74 & & 38 & 13 & 26 \\
& $100 \%$ & 3,16 & 36,82 & 29,36 & & 15,07 & 5,14 & 10,32 \\
\hline \multirow{2}{*}{$1850-52$} & 36 & 5 & & 6 & & 9 & 12 & 4 \\
& $100 \%$ & 13,88 & & 16,66 & & 24,93 & 33,32 & 11,11 \\
\hline \multirow{2}{*}{ Összesen: } & 951 & 40 & 278 & 275 & 3 & 214 & 67 & 74 \\
& $100 \%$ & 4,2 & 29,19 & 28,87 & 0,31 & 22,47 & 7,03 & 7,77 \\
\hline
\end{tabular}

A felső tagozaton a legszámottevőbb a nemesi származású diákréteg, 318 tanuló (33,39\%); 40 (4,20\%) közülük birtokos nemes, 278 (29,19\%) pedig kisnemesi családból való.

A polgárok rétegét 275 diák képviseli $(28,87 \%)$. Jelentős az értelmiségi és a papi családból származó diákság száma is (214 diák, 22,47\%). Amint táblázataink tanúsítják, sok földmüves, kisgazda (67 diák, 7,03\%) is taníttatta gyermekét. Ezek főként Szatmár és Németi földmüves lakosainak gyermekei. Egyéb ${ }^{106}$ származású 74 diák (7,77\%).

Minthogy az 1820-1855-ös évekből az alsóbb osztályok, sőt az elemi iskolák tanulóinak társadalmi eredetét, tehát az egyes osztályok társadalmi összetételét is ismerjük, össze tudjuk hasonlítani a kollégium alsóbb és felsőbb osztályait, s megállapíthatjuk, hogy az egyes társadalmi osztályok, illetőleg rétegek milyen mértékben és milyen fokon iskoláztatták gyermekeiket.

Az alsóbb osztályok tanulói társadalmi eredetének vizsgálatára a fenti időszakból öt évet választottunk, minden évtized kezdő évét, tehát az 1820-as, 1830-as, 1840-es és 1850-es évet, s történelmi jelentősége kapcsán az 1848-as évet. A kollégium négy alsó osztályának, illetőleg a kollégium keretében müködő Nagyobb Nemzeti Iskola - később Polgári Iskola -, valamint a Kisebb Nemzeti Iskola, később Református Kezdő Iskola, majd Elemi Iskola tanulóinak társadalmi eredetét a jelzett tanévekben a 9. számú, iskolatípusonként összesítve a 10. számú táblázatunkon mutatjuk be:

\footnotetext{
106 Ide soroltuk azokat, akiknél az apa állapotát - azaz a foglalkozást - jelölő rovatban a magánzó megjelölés, vagy az apa neve és foglalkozása helyett az özvegy édesanya neve szerepel, valamint mindazokat, akiknél a rovat kitöltetlen.
} 
9. számú táblázat

A kollégium alsó osztályaiban, valamint a polgári iskolában és az elemiben járók társadalmi eredete

\begin{tabular}{llllllll}
\hline Év Osztály & $\begin{array}{l}\text { Lét- } \\
\text { szám }\end{array}$ & $\begin{array}{l}\text { Ne- } \\
\text { mes }\end{array}$ & $\begin{array}{l}\text { Pol- } \\
\text { gár }\end{array}$ & $\begin{array}{l}\text { Kato- } \\
\text { na }\end{array}$ & $\begin{array}{l}\text { Értel- } \\
\text { miségi }\end{array}$ & $\begin{array}{l}\text { Föld- } \\
\text { mủves }\end{array}$ & Egyéb \\
\hline
\end{tabular}

1820

I. osztályos

grammatista

II. osztályos

grammatista

$25-3-9$

7

24

Novicius syntaxista 24

Veteranus syntaxista 18

Kisebb Nemzeti

Iskola

84

67

15

$\begin{array}{lll}24 & 2 & 10\end{array}$

$6 \quad 1$

$\begin{array}{lll}8 & 2 & 11\end{array}$

41

1830

I. osztályos

grammatista

II. osztályos

grammatista

III. osztályos

grammatista

IV. osztályos

grammatista

Nagyobb Nemzeti

Iskola

Kisebb Nemzeti

Iskola

$\begin{array}{llllll}50 & 5 & 40 & 2 & 2 & 1 \\ 37 & 5 & 23 & 7 & 2 & \\ 28 & 2 & 21 & 2 & 3 & \\ 29 & 2 & 19 & 5 & 2 & 1 \\ 60 & 2 & 46 & 2 & 9 & 1 \\ 149 & 3 & 112 & 5 & 21 & \end{array}$

1840

I. éves grammatista 24

II. éves grammatista 26

$\begin{array}{lll}4 & 3 & 14\end{array}$

I. éves syntaxista 14

II. éves syntaxista

14
8

$\begin{array}{rrr}16 & & 3 \\ 6 & 2 & 3 \\ 5 & 1 & 2\end{array}$




\begin{tabular}{llllllll}
\hline Év Osztály & $\begin{array}{l}\text { Lét- } \\
\text { szám }\end{array}$ & $\begin{array}{l}\text { Ne- } \\
\text { mes }\end{array}$ & $\begin{array}{l}\text { Pol- } \\
\text { gár }\end{array}$ & $\begin{array}{l}\text { Kato- } \\
\text { na Értel- }\end{array}$ & $\begin{array}{l}\text { Föld- } \\
\text { miségi }\end{array}$ & $\begin{array}{l}\text { mủves } \\
\text { múb }\end{array}$ \\
\hline
\end{tabular}

Kisebb polgári

nemzeti iskola

$\begin{array}{lrrrrrrr}\text { I. oszt. } & 54 & 4 & 36 & 1 & 3 & 8 & 2 \\ \text { II. vagy utóosztály } & 58 & 7 & 35 & & & 10 & 6\end{array}$

Református kezdő iskola

$\begin{array}{lrrrrrr}\text { I. osztály } & 36 & 3 & 22 & 2 & 3 & 6 \\ \text { II. osztály } & 35 & & 20 & & 1 & 14 \\ \text { III. osztály } & 64 & 3 & 35 & & 8 & 18\end{array}$

1848

I. éves grammatista $11 \quad 2 \quad 8$

II. éves grammatista $12 \quad 2 \quad 6$

I. éves latin szófüzők $11 \quad 4 \quad 3$

II. éves latin szófüzők $10 \quad 1 \quad 2$

Felsőbb polgári iskola

\begin{tabular}{|c|c|c|c|c|c|}
\hline I. osztály & 25 & & 24 & & \\
\hline II. osztály & 21 & & 15 & & 5 \\
\hline III. osztály & 25 & 2 & 17 & 1 & 4 \\
\hline
\end{tabular}

Alsóbb polgári iskola

$\begin{array}{lllllll}\text { I. osztály } & 22 & 1 & 13 & 1 & 7 & \\ \text { II. osztály } & 36 & & 27 & 3 & 4 & 2\end{array}$

Elemi iskola

$\begin{array}{llllll}\text { Alsó osztály } & 80 & 56 & 3 & 4 & 17 \\ \text { Felső osztály } & 50 & 35 & 2 & 3 & 10\end{array}$

1850

Grammatisták, I. 23

Grammatisták, II. $\quad 9$

Latin szófüzők, I. 9

Latin szófüzők, II. 5

4. osztályú népiskola

$\begin{array}{lllll}\text { I. oszt. } & 25 & 24 & 1 & 4 \\ \text { II. oszt. } & 20 & 15 & 1\end{array}$

3. osztályú népiskola

$\begin{array}{lllllr}\text { I. oszt. } & 24 & 15 & 3 & 2 & 4 \\ \text { II. oszt. } & 20 & 14 & 1 & 2 & 3 \\ \begin{array}{l}\text { osztályú népiskola } \\ \text { Alsó elemi iskola }\end{array} & 56 & 39 & 1 & 3 & 13 \\ \text { Alsó osztály } & 47 & 29 & 1 & 3 & 14 \\ \text { Felső osztály } & 45 & 31 & 2 & 3 & 9\end{array}$




\section{0. számú táblázat}

A kollégium alsó osztályos tanulóinak, a polgári iskolába és az elemi iskolába járó tanulóknak társadalmi eredete az 1820-1850-es évek átlagában

Év Létszám Nemes Polgár Katona Értelmiségi Földműves Egyéb

A kollégium alsóbb osztályai:

\begin{tabular}{rrrrlrrr}
1820 & 92 & 16 & 38 & 1 & 13 & 13 & 11 \\
1830 & 144 & 14 & 103 & & 16 & 9 & 2 \\
1840 & 72 & 7 & 41 & 3 & 12 & 5 & 4 \\
1848 & 44 & 9 & 19 & & 8 & 8 & \\
1850 & 46 & 8 & 16 & & 11 & 8 & 3 \\
\hline Összesen: 398 & 54 & 217 & 4 & 60 & 43 & 20 \\
$\%$ & 100 & 13,56 & 54,25 & 1,00 & 15,00 & 10,80 & 5,12
\end{tabular}

Nagyobb nemzeti iskola/Polgári iskola:

$1820 \quad$ Nem írták be!

$\begin{array}{rrrrrrrr}1830 & 60 & 2 & 46 & & 2 & 9 & 1 \\ 1840 & 112 & 11 & 71 & 1 & 3 & 18 & 8 \\ 1848 & 129 & 3 & 96 & & 5 & 14 & 11 \\ 1850 & 145 & & 107 & & 7 & 7 & 24\end{array}$

$\begin{array}{lccclccc}\text { Összesen: } 446 & 16 & 320 & 1 & 17 & 48 & 44 \\ \% & 100 & 3,68 & 71,68 & 0,22 & 3,81 & 10,75 & 9,86\end{array}$

Elemi iskola:

\begin{tabular}{lrlrrrr}
1820 & 84 & & 57 & 2 & 3 & 22 \\
1830 & 149 & 3 & 112 & 5 & 21 & 8 \\
1840 & 135 & 6 & 77 & 2 & 12 & 38 \\
1848 & 130 & & 91 & 5 & 7 & 27 \\
1850 & 92 & & 60 & 3 & 6 & 23 \\
& & & & & & \\
\hline \multicolumn{2}{l}{ Összesen: 590} & 9 & 397 & 17 & 49 & 118 \\
$\%$ & 100 & 1,71 & 67,08 & 2,87 & 8,28 & 19,94 \\
\hline
\end{tabular}


Az összesített adatok százalékarányát átlagosnak fogadva el, megállapíthatjuk, hogy a kollégium négy alsó osztályában sokkal - 20,08 százalékkal - kevesebb a nemesi származású diák, mint a felső tagozaton, mintegy hét és fél százalékkal kisebb az értelmiség részaránya is, viszont 4,22 százalékkal nagyobb a városi földmüves és a jobbágyszármazású diákok jelenléte, és több mint 25 százalékkal a városi iparos rétegek gyermekeinek a száma.

Világosan kikövetkeztethető, hogy az iparosság és a városi földmüvesek, valamint a jobbágyok gyermekei közül sokkal kevesebb tanult tovább, mint a nemesi, értelmiségi és szabad polgári származású családokból.

Az iparos és a földműves réteg gyermekei közül az 1820 és 1855 közötti időszakban igen sokan nem a kollégium (gimnázium) alsóbb osztályaiban tanultak tovább az elemi iskola elvégzése után, hanem az anyanyelven oktató ún. Nagyobb Magyar Fiú Oskolában, illetőleg 1837-től az ebből alakult Polgári Iskolában. Ebben az iparosság gyermekei alkották a diákság 85,57 százalékát, a földmüveseké pedig a 10,75 százalékát.

A kollégium épületében és keretében müködő elemi iskola tanulóinak többsége $(67,08 \%)$ a polgárság gyermekeit ölelte fel, de jelentős volt a zsellér- és szolgacsaládok $(19,94 \%)$ és a földmüves gazdák itt tanuló gyermekeinek számaránya (8,28\%) is. Az elemiben tanulók 2,77 százaléka származott értelmiségi, 1,71 százaléka nemesi családból.

A kollégium, valamint a keretében müködő polgári és elemi iskolák a Szatmáron lakó tanköteles korú református fiúgyermekeknek átlag 30 százalékát iskolázták. A beiskolázás aránya nyilvánvalóan más volt a kollégiumi osztályokban és más a polgári iskolában, illetőleg az elemiben. A következő táblázat ezt szemléletesen érzékelteti:

$\begin{array}{llllc}\text { Az osztályok } & \begin{array}{l}\text { A tanulók } \\ \text { átlagos }\end{array} & \% & \text { Közülük } & \text { A lét- A város református } \\ \text { (évi) } & & \text { szatmári } & \text { számhoz fiúgyermekeinek } \\ \text { száma } & & \text { ségü- } & \text { számához } \\ & & & \begin{array}{c}\text { viszonyítva } \\ (\%-b a n)\end{array}\end{array}$

A kollégium felső

osztályai 29

A kollégium alsó osztályai $\quad 104$

Polgári iskola 75

Elemi iskola 147

$\begin{array}{rrrr}100 & 14 & 48,27 & 5,98 \\ 100 & 72 & 69,23 & 15,51 \\ 100 & 74 & 98,66 & 15,95 \\ 100 & 147 & 100,00 & 31,68\end{array}$

Összesen: $\quad 355 \quad 100 \quad 297 \quad 83,66 \quad 30,30$




\section{A diákság létszáma, származási helye és társadalmi összetétele az abszolutizmus korától a második világháború végéig}

Az 1862-1944 közti időszakban mintegy 21337 diák ${ }^{107}$ tanult a szatmári református gimnáziumban, közülük 6596 a felsőbb osztályokban, 14741 az alsó tagozaton. Az osztályok létszámáról - az iskolai értesítők nyomtatásban megjelent adatai alapján - statisztikai táblázatunk tájékoztat:

\section{1. számú táblázat}

\section{A gimnázium nyilvános tanulóinak létszáma}

\begin{tabular}{|c|c|c|c|c|c|c|c|c|c|c|c|}
\hline \multirow[t]{2}{*}{ Év } & \multirow[b]{2}{*}{ I. } & \multicolumn{2}{|c|}{$\begin{array}{l}\text { Alsó tagozat } \\
\text { osztály }\end{array}$} & \multicolumn{3}{|c|}{ Összesen } & \multicolumn{3}{|c|}{$\begin{array}{l}\text { Felső tagozat } \\
\text { osztály }\end{array}$} & \multirow[t]{2}{*}{ Összesen } & \multirow{2}{*}{$\begin{array}{l}\text { Összesen } \\
\text { a gimná- } \\
\text { ziumban }\end{array}$} \\
\hline & & II. & III. & IV. & & V. & VI. & VII. & VIII. & & \\
\hline 1862 & 43 & 32 & 29 & 17 & 121 & 14 & 13 & - & - & 27 & 148 \\
\hline 1869 & & & & & & & & & & & 165 \\
\hline 1870 & 38 & 34 & 28 & 27 & 127 & 13 & 17 & - & - & 30 & 157 \\
\hline 1871 & 56 & 33 & 33 & 23 & 145 & 24 & 24 & - & - & 48 & 193 \\
\hline 1872 & 45 & 54 & 33 & 22 & 154 & 19 & 11 & - & - & 30 & 184 \\
\hline 1873 & 46 & 34 & 43 & 23 & 146 & 20 & 20 & - & - & 40 & 186 \\
\hline 1874 & 42 & 30 & 33 & 43 & 148 & 31 & 11 & - & - & 32 & 180 \\
\hline 1875 & 58 & 38 & 30 & 25 & 151 & 32 & 14 & - & - & 46 & 197 \\
\hline 1876 & 62 & 36 & 33 & 21 & 152 & 20 & 22 & - & - & 42 & 194 \\
\hline 1877 & 57 & 35 & 36 & 21 & 149 & 17 & 19 & - & - & 36 & 185 \\
\hline 1878 & 61 & 49 & 35 & 21 & 166 & 20 & 12 & - & - & 32 & 198 \\
\hline 1879 & 43 & 45 & 42 & 32 & 162 & 17 & 13 & - & - & 30 & 192 \\
\hline
\end{tabular}

${ }^{107}$ Az 1862/63-as tanév diáklétszámát a Debreceni Kollégium levéltárában őrzött jegyzék - A helvét hitv. szatmárnémeti hat osztályú Gymnasium tanulóinak név és osztályzati jegyzéke az 1862/3-ik isk. év első feléről - alapján, az 1869. évtől kezdődő időszak diáklétszámát pedig az évenként megjelent iskolai értesítők alapján állítottam össze. Az értesítők a kolozsvári Egyetemi Könyvtárban A1480-as jelzettel, a marosvásárhelyi Teleki Könyvtárban Bo 26512-es jelzettel találhatók. 
\begin{tabular}{cccc}
\hline Év & Alsó tagozat & Felső tagozat & Összesen \\
osztály & Összesen & osztály & Összesen a gimná-
\end{tabular}

I. II. III. IV. V. VI. VII. VIII. Ziumban

\begin{tabular}{|c|c|c|c|c|c|c|c|c|c|c|c|}
\hline 1880 & 58 & 37 & 42 & 28 & 165 & 17 & 12 & - & - & 29 & 194 \\
\hline 1881 & 54 & 41 & 28 & 27 & 150 & 13 & 12 & - & - & 25 & 175 \\
\hline 1882 & 60 & 47 & 30 & 21 & 158 & 20 & 12 & - & - & 32 & 190 \\
\hline 1883 & 49 & 51 & 46 & 27 & 173 & 21 & 21 & - & - & 42 & 215 \\
\hline 1884 & 62 & 36 & 41 & 37 & 176 & 24 & 14 & - & - & 38 & 214 \\
\hline 1885 & 49 & 44 & 38 & 30 & 161 & 25 & 20 & - & - & 45 & 206 \\
\hline 1886 & 54 & 41 & 45 & 34 & 174 & 21 & 23 & - & - & 44 & 218 \\
\hline 1887 & 49 & 48 & 35 & 39 & 171 & 19 & 20 & - & - & 39 & 210 \\
\hline 1888 & 45 & 42 & 40 & 31 & 158 & 28 & 19 & - & - & 47 & 205 \\
\hline 1889 & 52 & 37 & 44 & 29 & 162 & 27 & 24 & - & - & 51 & 213 \\
\hline 1890 & 61 & 47 & 36 & 41 & 185 & 35 & 27 & 29 & - & 91 & 276 \\
\hline 1891 & 77 & 45 & 44 & 34 & 200 & 32 & 27 & 25 & 23 & 107 & 307 \\
\hline 1892 & 57 & 48 & 39 & 29 & 173 & 14 & 24 & 22 & 21 & 81 & 254 \\
\hline 1893 & 62 & 47 & 47 & 34 & 190 & 22 & 14 & 22 & 20 & 78 & 268 \\
\hline 1894 & 58 & 51 & 43 & 34 & 186 & 29 & 20 & 13 & 22 & 84 & 270 \\
\hline 1895 & 67 & 56 & 44 & 43 & 210 & 34 & 25 & 19 & 11 & 89 & 299 \\
\hline 1896 & 51 & 48 & 48 & 45 & 192 & 40 & 24 & 21 & 18 & 103 & 295 \\
\hline 1897 & 55 & 47 & 46 & 43 & 191 & 29 & 28 & 24 & 21 & 102 & 293 \\
\hline 1898 & 57 & 47 & 45 & 39 & 188 & 37 & 28 & 23 & 23 & 111 & 299 \\
\hline 1899 & 54 & 44 & 42 & 43 & 183 & 34 & 38 & 28 & 27 & 127 & 310 \\
\hline 1900 & 53 & 45 & 41 & 39 & 178 & 35 & 26 & 31 & 31 & 123 & 301 \\
\hline 1901 & 63 & 48 & 41 & 31 & 183 & 38 & 31 & 21 & 26 & 116 & 299 \\
\hline 1902 & 68 & 48 & 51 & 43 & 210 & 36 & 32 & 34 & 22 & 124 & 334 \\
\hline 1903 & 68 & 62 & 54 & 48 & 232 & 40 & 34 & 27 & 37 & 138 & 370 \\
\hline 1904 & 68 & 66 & 60 & 51 & 245 & 42 & 45 & 33 & 23 & 143 & 388 \\
\hline 1905 & 68 & 68 & 68 & 57 & 261 & 48 & 38 & 44 & 30 & 160 & 421 \\
\hline 1906 & 65 & 64 & 61 & 70 & 260 & 47 & 42 & 38 & 45 & 172 & 432 \\
\hline 1907 & 74 & 52 & 57 & 56 & 239 & 62 & 45 & 45 & 35 & 187 & 426 \\
\hline 1908 & 61 & 64 & 55 & 44 & 224 & 50 & 53 & 43 & 42 & 188 & 412 \\
\hline 1909 & 62 & 60 & 58 & 56 & 236 & 35 & 40 & 56 & 41 & 172 & 408 \\
\hline 1910 & 70 & 62 & 62 & 63 & 257 & 51 & 31 & 42 & 51 & 175 & 432 \\
\hline 1911 & 69 & 62 & 56 & 61 & 248 & 54 & 41 & 35 & 37 & 167 & 415 \\
\hline 1912 & 89 & 58 & 62 & 49 & 258 & 45 & 42 & 43 & 36 & 166 & 424 \\
\hline 1913 & 69 & 87 & 57 & 58 & 271 & 38 & 37 & 50 & 41 & 166 & 437 \\
\hline 1914 & 68 & 59 & 77 & 57 & 261 & 48 & 38 & 33 & 47 & 164 & 425 \\
\hline 1915 & 64 & 63 & 63 & 66 & 256 & 36 & 42 & 26 & 48 & 152 & 408 \\
\hline 1916 & 74 & 53 & 65 & 66 & 258 & 47 & 34 & 37 & 12 & 130 & 388 \\
\hline 1917 & 69 & 67 & 57 & 57 & 250 & 55 & 45 & 29 & 28 & 157 & 407 \\
\hline 1918 & 72 & 70 & 70 & 54 & 266 & 59 & 60 & 44 & 21 & 184 & 450 \\
\hline
\end{tabular}




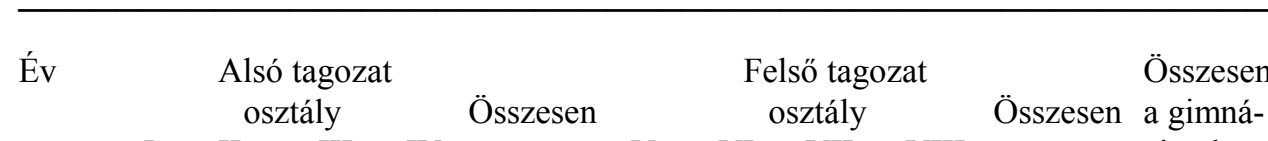

I. II. III. IV. V. VI. VII. VIII. ziumban

\begin{tabular}{rrrrrrrrrrrr}
\hline 1919 & 99 & 156 & 132 & 149 & 538 & 100 & 103 & 95 & 94 & 393 & 930 \\
1920 & 98 & 83 & 69 & 72 & 322 & 62 & 43 & 46 & 50 & 201 & 523 \\
1921 & 70 & 78 & 51 & 53 & 252 & 40 & 45 & 36 & 39 & 160 & 412 \\
1922 & 49 & 52 & 75 & 53 & 229 & 32 & 31 & 42 & 29 & 134 & 363 \\
1923 & 37 & 40 & 54 & 61 & 192 & 25 & 31 & 25 & 37 & 118 & 310 \\
1924 & 30 & 26 & 26 & 39 & 121 & 21 & 12 & 17 & 15 & 65 & 186 \\
1925 & 44 & 32 & 18 & 14 & 108 & 10 & 17 & 11 & 6 & 44 & 152 \\
1926 & 49 & 22 & 32 & 13 & 116 & 15 & 9 & 12 & 4 & 40 & 156 \\
1927 & 28 & 36 & 19 & 18 & 101 & 13 & 14 & 6 & 8 & 41 & 142 \\
1928 & 27 & 23 & 30 & - & 80 & - & - & - & - & - & 80 \\
1929 & 42 & 16 & 18 & - & 76 & - & - & - & - & - & 76 \\
1930 & 46 & 30 & 17 & 6 & 99 & - & - & - & - & - & 99 \\
1931 & 46 & 28 & 27 & 14 & 115 & 8 & - & - & - & 8 & 123 \\
1932 & 47 & 46 & 32 & 22 & 147 & 14 & 9 & - & - & 23 & 170 \\
1933 & 55 & 39 & 46 & 29 & 169 & 18 & 14 & 9 & - & 41 & 210 \\
1934 & 48 & 45 & 39 & 45 & 177 & 14 & 18 & 14 & - & 46 & 223 \\
1935 & 44 & 38 & 39 & 32 & 153 & 21 & 14 & 18 & 12 & 65 & 218 \\
1936 & 41 & 33 & 34 & 34 & 142 & 17 & 19 & 13 & 17 & 66 & 185 \\
1937 & 31 & 36 & 25 & 27 & 119 & 21 & 20 & 15 & 10 & 66 & 185 \\
1938 & 40 & 31 & 29 & 26 & 126 & 18 & 21 & 18 & 13 & 70 & 196 \\
1939 & 48 & 36 & 26 & 29 & 139 & 28 & 23 & 16 & 18 & 85 & 224 \\
1940 & 108 & 60 & 49 & 37 & 254 & 40 & 35 & 28 & 31 & 134 & 388 \\
1941 & 149 & 104 & 92 & 48 & 393 & 36 & 44 & 28 & 30 & 138 & 531 \\
1942 & 130 & 130 & 108 & 86 & 454 & 38 & 33 & 36 & 27 & 134 & 588 \\
& & & & & & & & & & & \\
\hline & & & & & & & & & & & \\
\hline
\end{tabular}


E korszak diákságának származási helyéről a következő táblázat tájékoztat:

\section{2. számú táblázat}

\section{A tanulók származási helye (1862-1942 közt)}

\begin{tabular}{|c|c|c|c|c|c|c|}
\hline Év & Helybeli & Megyebeli & $\begin{array}{l}\text { Más - } \\
\text { megyebeli }\end{array}$ & $\begin{array}{l}\text { Horvát- és } \\
\text { Szlavonországból }\end{array}$ & $\begin{array}{l}\text { Más állam- } \\
\text { ból }\end{array}$ & $\begin{array}{l}\text { Össze- } \\
\text { sen }\end{array}$ \\
\hline
\end{tabular}

1862

1869

1870

1871

1872

1873

$1874 \quad 103$

$1875 \quad 80$

1876

1877

$1878 \quad 150$

$1879 \quad 154$

$1880 \quad 54$

$1881 \quad 56$

$1882 \quad 57$

$1883 \quad 68$

$1884 \quad 73$

$1885 \quad 74$

$1886 \quad 87$

$1887 \quad 69$

$1888 \quad 68$

$1889 \quad 68$

$1890 \quad 81$

$1891 \quad 123$

$1892 \quad 118$

$1893 \quad 116$

$1894 \quad 101$

$1895 \quad 124$

$1896 \quad 126$

$1897 \quad 124$

$1898 \quad 118$

$1899 \quad 131$

$1900 \quad 124$

$1901 \quad 130$

$1902 \quad 142$

$1903 \quad 176$

$1904 \quad 180$

$1905 \quad 201$

$1906 \quad 200$

$1907 \quad 183$

$1908 \quad 184$

$1909 \quad 211$

$1910 \quad 196$

$1911 \quad 187$

119
64
$76 \quad 33$

13

33

38

38

33

28

25

36

25

22

21

22

28

34

55

37

36

30

22

26

30

23

40

36

44

43

29

41

43

48

39

42

51

44

73

66
148

165

157

193

187

186

180

189

194

185

188

192

175

175

179

199

189

186

195

181

190

201

243

276

248

253

252

281

278

293

298

298

300

292

332

366

390

424

416

405

410

415

430

1

410 


$\begin{array}{rrrrrc}1912 & 180 & 174 & 61 & 3 & 418 \\ 1913 & 194 & 161 & 82 & 4 & 441 \\ 1914 & 212 & 133 & 72 & & 417 \\ 1915 & 225 & 127 & 47 & & 399 \\ 1916 & 249 & 141 & 56 & 1 & 447 \\ 1917 & 265 & 157 & 48 & & 470 \\ 1918 & 264 & 150 & 36 & 94 & 450 \\ 1919 & 175 & 220 & 34 & 2 & 37 \text { lány } \\ + & 30 & 5 & & 5 & 442 \\ 1920 & 303 & 130 & 4 & 5 & 438 \text { lány } \\ + & 22 & 4 & & 12 & 403 \\ 1921 & 320 & 94 & 19 & 4 & 312 \\ 1922 & 258 & 116 & 17 & 2 & 183 \\ 1923 & 226 & 78 & 4 & & 151 \\ 1924 & 138 & 42 & 1 & 1 & 155 \\ 1925 & 119 & 31 & 1 & & 162 \\ 1926 & 100 & 42 & 12 & & 84 \\ 1927 & 115 & 47 & & & 85 \\ 1928 & 51 & 33 & & 1 & 581 \\ 1929 & 58 & 27 & & 1 & 588 \\ 1930 & 70 & 36 & & & \end{array}$

E statisztikából nem derül ki, milyen az alsóbb és a felsőbb osztályosok területi hovatartozása, ezért csupán feltételezzük, hogy a nem helybeliek és a más megyéből valók többsége felsőbb osztályos lehetett.

A két és fél évtizednyi időszak alatt itt tanult 21337 diák közül 17 429-nek ismerjük a lakóhelyét. Közülük 8365 volt Szatmárnémetibe való, 6931 Szatmár megyei, 1972 más megyéből, 161 pedig más országból származó. Amint ezek az adatok tanúsítják, a gimnázium a XIX. században túlnyomórészt a Szatmár városi és a Szatmár megyebeli diákság taníttatását szolgálta.

Az 1878-1891 közötti, valamint az 1941-es és 1942-es értesítők a más megyebeli diákok származását megyénként is felsorolják. Ezekből a kimutatásokból megállapítható, hogy a más megyebeliek többsége ez idő tájt a szomszédos megyékből származott (Ugocsa 83, Szabolcs 44, Bihar 38, Bereg 31, Közép-Szolnok 22, Máramaros 15, Hajdú 15).

A Habsburg-monarchia más országaiból, illetve külföldről ebben az időszakban Bukovinából (6), Galíciából (4), Ausztriából (3), Szlavóniából (1) és Angliából (1) tanultak a gimnáziumban.

A más megyebeli tanulók lakóhelyét az előbbi időszakokban 13. számú táblázatunk mutatja be: 


\section{3. számú táblázat}

A más megyebeli tanulók származási helye (1878-1891 és 1941-1943 között)

\begin{tabular}{|c|c|c|c|c|c|c|c|c|c|c|c|c|c|c|c|c|}
\hline $\begin{array}{l}\text { A megye } \\
\text { (ország) }\end{array}$ & $\stackrel{\infty}{\infty}$ & $\stackrel{a}{\infty}$ & $\begin{array}{l}\sim \\
\infty \\
\infty\end{array}$ & $\begin{array}{l}\infty \\
\infty\end{array}$ & $\underset{\infty}{+}$ & $\begin{array}{l}\infty \\
\infty \\
\infty\end{array}$ & $\begin{array}{l}0 \\
\infty \\
\infty\end{array}$ & $\hat{\infty}$ & $\begin{array}{l}\infty \\
\infty \\
\infty\end{array}$ & $\begin{array}{l}\infty \\
\infty \\
\infty\end{array}$ & ஓి & 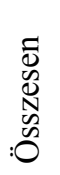 & ‡ & $\stackrel{\text { I }}{2}$ & $\begin{array}{l}\text { D్ } \\
\mathbb{N} \\
N \\
0 \\
: 0\end{array}$ & $\begin{array}{l}00 \\
0 \\
0 \\
0 \\
: 00 \\
0 \\
0\end{array}$ \\
\hline Arad & 3 & 5 & & & & 1 & 1 & & & & & 10 & & & & 10 \\
\hline Bars & & & & & & & & & & & & & & 1 & 1 & 1 \\
\hline Bereg & 1 & 1 & 6 & 3 & 3 & & 2 & 5 & 1 & 2 & 7 & 31 & 1 & & 1 & 32 \\
\hline \multicolumn{17}{|l|}{ Beszterce- } \\
\hline Naszód & & & & & & & & & & 3 & 2 & 5 & & & & 5 \\
\hline Bihar & 1 & 2 & 2 & 1 & 6 & 5 & 2 & 3 & 5 & 5 & 6 & 38 & & & & 38 \\
\hline Borsod & & & & & & & & & & & & & & 1 & 1 & 1 \\
\hline Csanád & & & & & & & & & & & & & & 1 & 1 & 1 \\
\hline Csongrád & & & & 1 & & & & & & & & 1 & 2 & 1 & 3 & 4 \\
\hline Fejér & & & & & & 1 & & & & & & 1 & 1 & 1 & 2 & 3 \\
\hline Gömör & & & & & & & & & 1 & 1 & & 2 & & & & 2 \\
\hline Hajdú & & & & 1 & & & 1 & 2 & 1 & 1 & & 6 & 7 & 5 & 12 & 18 \\
\hline Háromszék & & & & & & & & & & & & & 1 & & 1 & 1 \\
\hline Heves & & & & & & & & & & & & & & 1 & 1 & 1 \\
\hline \multicolumn{17}{|l|}{ Jász-Nagy- } \\
\hline kun-Szolnok & & & 1 & 2 & 1 & 1 & & & & & & 5 & & & & 5 \\
\hline Kolozs & & & 1 & 5 & 1 & 1 & 1 & & & 1 & & 10 & & & & 10 \\
\hline Komárom & & & & & & & & 1 & & 1 & & 2 & & & & 2 \\
\hline Máramaros & 7 & 3 & & 1 & & 1 & 1 & 1 & & & 1 & 15 & 2 & & 2 & 17 \\
\hline \multicolumn{17}{|l|}{ Nagy- } \\
\hline Küküllő & & & & & & & & 1 & & & & 1 & & & & 1 \\
\hline Nógrád & & & & & & 1 & 1 & 1 & 1 & & & 4 & 1 & 1 & 2 & 6 \\
\hline Pest & 2 & & & & 1 & & 1 & & & 2 & 1 & 7 & 1 & 7 & 8 & 15 \\
\hline Pozsony & & & & & & & & & & 1 & 1 & 2 & & & & 2 \\
\hline Szabolcs & 5 & 3 & 3 & 3 & & 2 & & 1 & 6 & 5 & 16 & 44 & 6 & 8 & 14 & 58 \\
\hline Szepes & & 1 & & 2 & 1 & 1 & & & 2 & 2 & 3 & 12 & & & & 12 \\
\hline Szilágy & 6 & 4 & 1 & 3 & & & 2 & 1 & 1 & 1 & 3 & 22 & 15 & 16 & 31 & 54 \\
\hline \multicolumn{17}{|l|}{ Szolnok- } \\
\hline Doboka & & 1 & 1 & 1 & 1 & & & & & 1 & & 5 & 1 & & 1 & 6 \\
\hline Temes & & & & & & & & & 1 & & & 1 & & & & 1 \\
\hline Tolna & & & & & & & & 1 & 1 & & & 2 & & & & 2 \\
\hline Ugocsa & 13 & 16 & 4 & 9 & 11 & 8 & 3 & 3 & 3 & 4 & 9 & 83 & 21 & 26 & 47 & 130 \\
\hline Ung & & & & 1 & & & & 1 & 1 & 1 & & 4 & & & & 4 \\
\hline Zala & & & & & & & & & & & & & 1 & 1 & 2 & 2 \\
\hline Zemplén & & & 2 & 2 & 1 & & & & 1 & & 2 & 8 & & & & 8 \\
\hline
\end{tabular}




\begin{tabular}{|c|c|c|c|c|c|c|c|c|c|c|c|c|c|c|c|c|}
\hline $\begin{array}{l}\text { A megye } \\
\text { (ország) }\end{array}$ & $\stackrel{\infty}{\infty}$ & 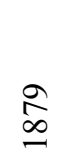 & $\begin{array}{l}\infty \\
\infty \\
\infty\end{array}$ & $\begin{array}{l}\infty \\
\infty \\
\infty\end{array}$ & $\begin{array}{l}+ \\
\infty \\
\infty\end{array}$ & $\begin{array}{l}\infty \\
\infty \\
\infty\end{array}$ & $\begin{array}{l}\infty \\
\infty \\
\infty\end{array}$ & $\stackrel{\infty}{\infty}$ & $\begin{array}{l}\infty \\
\infty \\
\infty\end{array}$ & $\begin{array}{l}\infty \\
\infty \\
\infty\end{array}$ & $\stackrel{\infty}{\infty}$ & 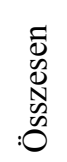 & 尹 & $\stackrel{\mathfrak{Z}}{\stackrel{2}{2}}$ & $\begin{array}{l}\overline{0} \\
\tilde{D} \\
\tilde{W} \\
: 0\end{array}$ & 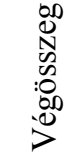 \\
\hline Anglia & & & & & & & & & & 1 & & 1 & & & & 1 \\
\hline Ausztria & & & & & & & & & 1 & 1 & 1 & 3 & & & & 3 \\
\hline Bukovina & 1 & 1 & 1 & 3 & & & & & & & & 6 & & & & 6 \\
\hline Galícia & & & & 1 & 1 & 1 & 1 & & & & & 4 & & & & 4 \\
\hline Szlavónia & 1 & & & & & & & & & & & 1 & & & & 1 \\
\hline Háromszék & & & & & & & & & & & & & 1 & & 1 & 1 \\
\hline Heves & & & & & & & & & & & & & & 1 & 1 & 1 \\
\hline \multicolumn{17}{|l|}{ Jász-Nagy- } \\
\hline kun-Szolnok & & & 1 & 2 & 1 & 1 & & & & & & 5 & & & & 5 \\
\hline Kolozs & & & 1 & 5 & 1 & 1 & 1 & & & 1 & & 10 & & & & 10 \\
\hline Komárom & & & & & & & & 1 & & 1 & & 2 & & & & 2 \\
\hline Máramaros & 7 & 3 & & 1 & & 1 & 1 & 1 & & & 1 & 15 & 2 & & 2 & 17 \\
\hline \multicolumn{17}{|l|}{ Nagy- } \\
\hline Küküllő & & & & & & & & 1 & & & & 1 & & & & 1 \\
\hline Nógrád & & & & & & 1 & 1 & 1 & 1 & & & 4 & 1 & 1 & 2 & 6 \\
\hline Pest & 2 & & & & 1 & & 1 & & & 2 & 1 & 7 & 1 & 7 & 8 & 15 \\
\hline Pozsony & & & & & & & & & & 1 & 1 & 2 & & & & 2 \\
\hline Szabolcs & 5 & 3 & 3 & 3 & & 2 & & 1 & 6 & 5 & 16 & 44 & 6 & 8 & 14 & 58 \\
\hline Szepes & & 1 & & 2 & 1 & 1 & & & 2 & 2 & 3 & 12 & & & & 12 \\
\hline Szilágy & 6 & 4 & 1 & 3 & & & 2 & 1 & 1 & 1 & 3 & 22 & 15 & 16 & 31 & 54 \\
\hline \multicolumn{17}{|l|}{ Szolnok- } \\
\hline Doboka & & 1 & 1 & 1 & 1 & & & & & 1 & & 5 & 1 & & 1 & 6 \\
\hline Temes & & & & & & & & & 1 & & & 1 & & & & 1 \\
\hline Tolna & & & & & & & & 1 & 1 & & & 2 & & & & 2 \\
\hline Ugocsa & 13 & 16 & 4 & 9 & 11 & 8 & 3 & 3 & 3 & 4 & 9 & 83 & 21 & 26 & 47 & 130 \\
\hline Ung & & & & 1 & & & & 1 & 1 & 1 & & 4 & & & & 4 \\
\hline Zala & & & & & & & & & & & & & 1 & 1 & 2 & 2 \\
\hline Zemplén & & & 2 & 2 & 1 & & & & 1 & & 2 & 8 & & & & 8 \\
\hline Anglia & & & & & & & & & & 1 & & 1 & & & & 1 \\
\hline Ausztria & & & & & & & & & 1 & 1 & 1 & 3 & & & & 3 \\
\hline Bukovina & 1 & 1 & 1 & 3 & & & & & & & & 6 & & & & 6 \\
\hline Galícia & & & & 1 & 1 & 1 & 1 & & & & & 4 & & & & 4 \\
\hline Szlavónia & 1 & & & & & & & & & & & 1 & & & & 1 \\
\hline
\end{tabular}


A fenti korszak diákságának társadalmi eredetéről a 14-es számú táblázat tájékoztat. ${ }^{108}$

\section{4. számú táblázat}

\section{A gimnázium tanulóinak társadalmi eredete (1869-1944 között)}

(1869-1881)

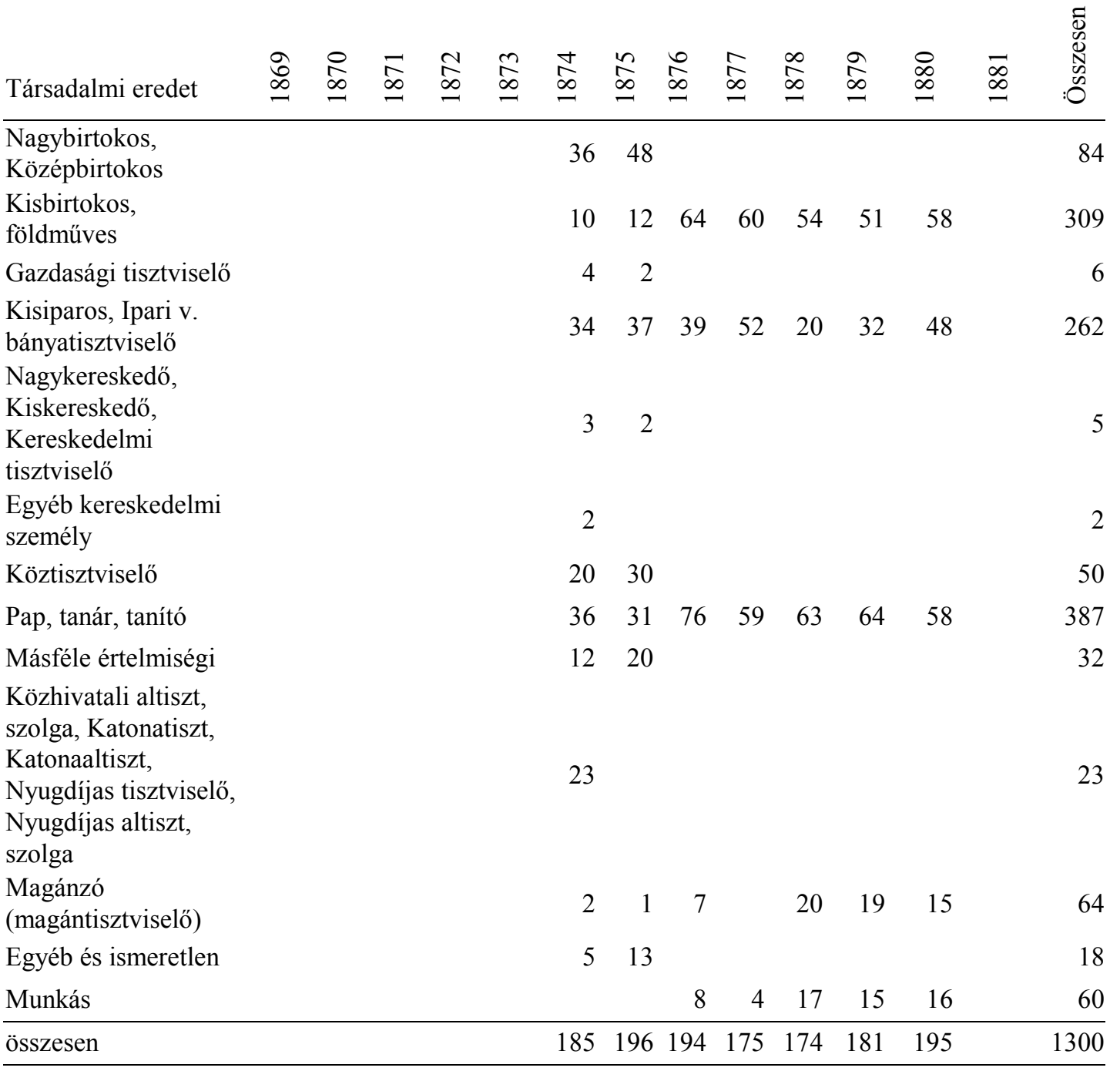

${ }^{108}$ Eltérés mutatkozik több értesítõben a diáklétszámról, illetõleg a tanulók társadalmi eredetérõl közölt adatok és végösszegek közt. Pontatlanok a tanulók vallási hovatartozására és nyelvi ismereteire vonatkozó táblázatok is. Konkrétan az 1875, 1876, 1877, 1881, 1886, 1894, 1895, 1911, 1923. és 1941. évi értesítõkben találtam ilyen pontatlanságokat. Az adatokat változatlanul közlöm, de a fenti okból a táblázatok végösszegét nem készítettem el. 
(1882-1890)

Társadalmi eredet

$\begin{array}{llllllllll}1882 & 1883 & 1884 & 1885 & 1886 & 1887 & 1888 & 1889 & 1890 & \text { Összesen }\end{array}$

Nagybirtokos,

Középbirtokos

Kisbirtokos, földmüves

$37 \quad 46$

$54 \quad 42$

44

$53 \quad 45$

$46 \quad 64$

431

Gazdasági tisztviselő

Kisiparos, Ipari v.

bányatisztviselö

50

$\begin{array}{llll}58 & 64 & 48 & 48\end{array}$

$48 \quad 52$

462

Nagykereskedö,

Kiskereskedő,

Kereskedelmi tisztviselö

Egyéb kereskedelmi

személy

Köztisztviselő

Pap, tanár, tanító

$39 \quad 62$

$62 \quad 38$

$38 \quad 51$

1446

475

Másféle értelmiségi

Közhivatali altiszt, szolga, Katonatiszt, Katonaaltiszt, Nyugdíjas tisztviselö,

$\begin{array}{llllllll}26 & 37 & 9 & 13 & 23 & 36 & 53 & 197\end{array}$

Nyugdíjas altiszt, szolga

Magánzó

$\begin{array}{llllllllll}14 & 4 & 17 & 14 & 6 & 17 & 13 & 22 & 22 & 129\end{array}$

(magántisztviselő)

Egyéb és ismeretlen

\begin{tabular}{lrrrrrrrrrr} 
Munkás & 1 & 9 & 7 & 10 & 10 & 12 & 12 & 11 & 6 & 78 \\
\hline összesen & 178 & 200 & 186 & 200 & 195 & 181 & 190 & 197 & 243 & 1770 \\
\hline
\end{tabular}


(1891-1907)

\begin{tabular}{|c|c|c|c|c|c|c|c|c|c|c|c|c|c|c|c|c|c|c|}
\hline & $\bar{\infty}$ & $\stackrel{\curvearrowright}{\check{\infty}}$ & $\stackrel{\varrho}{\infty}$ & $\underset{\infty}{\stackrel{\Delta}{ }}$ & $\stackrel{\mathscr{\partial}}{\stackrel{\infty}{-}}$ & $\stackrel{\text { ஃे }}{\stackrel{2}{-}}$ & $\stackrel{\infty}{\infty}$ & $\stackrel{\infty}{\stackrel{\infty}{-}}$ & 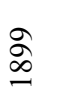 & $\stackrel{\text { }}{\varrho}$ & ळ & §̊ & ๙̊ & ষ্ণ & $\stackrel{\wp}{\varrho}$ & ๖ & $\hat{\circ}$ & $\begin{array}{l}\text { N } \\
\text { : } \\
: 0\end{array}$ \\
\hline Nagybirtokos & 38 & 17 & 12 & 6 & 5 & 11 & 22 & 20 & 25 & 11 & 7 & 11 & 13 & 16 & 8 & 11 & 25 & 258 \\
\hline kisbirtokos & 46 & 51 & 64 & 74 & 88 & 66 & 72 & 86 & 71 & 79 & 85 & 94 & 103 & 99 & 121 & 122 & 105 & 1426 \\
\hline alkalmazott & 13 & 12 & 11 & 7 & 6 & 4 & 8 & 5 & 6 & 12 & 6 & 7 & 2 & 1 & 3 & 2 & 6 & 111 \\
\hline nagyiparos & & 2 & 3 & & 1 & 2 & 1 & 1 & 1 & 1 & 2 & 1 & 34 & 1 & 4 & & 3 & 57 \\
\hline kisiparos & 35 & 31 & 36 & 32 & 38 & 33 & 36 & 34 & 33 & 29 & 28 & 31 & 2 & 33 & 47 & 44 & 50 & 572 \\
\hline ipari alkalmazott & & 2 & 2 & 2 & 3 & 4 & 1 & & & 1 & 3 & 1 & 7 & & & & & 26 \\
\hline nagykereskedő & 6 & 3 & 2 & 1 & 2 & 2 & 1 & 4 & 4 & 1 & 4 & 6 & 20 & 7 & 5 & 4 & 6 & 78 \\
\hline kiskereskedő & 11 & 11 & 12 & 10 & 21 & 30 & 23 & 16 & 21 & 24 & 14 & 19 & 2 & 17 & 16 & 8 & 9 & 264 \\
\hline $\begin{array}{l}\text { kereskedelmi } \\
\text { alkalmazott }\end{array}$ & & & 1 & 1 & 2 & 3 & 2 & 1 & & & 6 & 2 & 62 & 1 & 3 & 3 & 3 & 90 \\
\hline állami tisztviselő & 31 & 43 & 40 & 40 & 36 & 42 & 40 & 43 & 48 & 49 & 40 & 55 & 11 & 76 & 68 & 70 & 54 & 786 \\
\hline magántisztviselő & 13 & 7 & 10 & 9 & 9 & 9 & 6 & 6 & 6 & 8 & 7 & 6 & 10 & 14 & 13 & 13 & 9 & 155 \\
\hline katona & 3 & 2 & 1 & 1 & 2 & 2 & 3 & 2 & & & & & & & & 2 & 1 & 19 \\
\hline más értelmiségi & 62 & 46 & 41 & 51 & 45 & 82 & 52 & 52 & 56 & 46 & 54 & 66 & 64 & 73 & 82 & 84 & 90 & 1046 \\
\hline $\begin{array}{l}\text { munkás, } \\
\text { napszámos }\end{array}$ & 9 & 8 & 4 & 6 & 7 & 7 & 4 & 7 & 6 & 8 & 7 & 12 & 10 & 13 & 13 & 17 & 13 & 151 \\
\hline $\begin{array}{l}\text { magánzó, } \\
\text { nyugdíjas }\end{array}$ & 9 & 13 & 14 & 12 & 16 & 19 & 22 & 21 & 21 & 31 & 29 & 21 & 36 & 39 & 41 & 36 & 31 & 411 \\
\hline Összesen: & 276 & 248 & 253 & 252 & 281 & 316 & 293 & 298 & 298 & 300 & 292 & 332 & 376 & 390 & 424 & 416 & 405 & 5450 \\
\hline
\end{tabular}




\begin{tabular}{|c|c|c|c|c|c|c|c|c|c|c|c|c|c|c|}
\hline & $\stackrel{\infty}{\circ}$ & ஓे & $\frac{0}{2}$ & $\bar{\Xi}$ & $\frac{2}{2}$ & $\frac{m}{2}$ & $\frac{\Delta}{a}$ & $\frac{n}{2}$ & $\frac{6}{2}$ & $\frac{1}{2}$ & $\frac{\infty}{2}$ & $\frac{a}{2}$ & ๙ิ & : \\
\hline Nagybirtokos & 3 & 5 & 4 & 4 & & 2 & 4 & 3 & 2 & 3 & 2 & 19 & 7 & 58 \\
\hline Középbirtokos & 34 & 32 & 24 & 21 & 13 & 18 & 12 & 14 & 31 & 16 & 23 & & 5 & 243 \\
\hline Kisbirtokos, földmüves & 74 & 75 & 72 & 57 & 86 & 83 & 58 & 52 & 41 & 61 & 71 & 195 & 55 & 983 \\
\hline Gazdasági, tisztviselő & 4 & 4 & 3 & 9 & & 5 & 6 & 4 & 1 & 6 & 4 & & & 46 \\
\hline Alkalmazott, napszámos & & 2 & 4 & & & & & & & & & & & 6 \\
\hline Gyáros & & 2 & 2 & & 3 & & & & & & & 98 & 2 & 110 \\
\hline Kisiparos & 50 & 44 & 47 & 43 & 44 & 40 & 42 & 43 & 44 & 48 & 49 & 128 & 86 & 708 \\
\hline Ipari v. bányatisztviselö & 1 & 8 & 3 & 4 & & 4 & 4 & 1 & 2 & 3 & & & & 30 \\
\hline Egyéb ipari segédszemélyzet & 2 & 3 & 5 & 4 & 2 & 2 & 3 & 4 & & 2 & & & & 21 \\
\hline Nagykereskedő & 2 & 3 & 5 & 4 & 2 & 2 & 3 & 4 & 3 & & 7 & 5 & 6 & 46 \\
\hline Kiskereskedő & 5 & 7 & 16 & 11 & 18 & 16 & 21 & 20 & 33 & 41 & 40 & 31 & 54 & 313 \\
\hline $\begin{array}{l}\text { Kereskedelmi v. közlekedési } \\
\text { tisztviselö }\end{array}$ & 24 & 27 & 37 & 32 & 39 & 37 & 41 & 36 & 32 & 41 & 9 & & & 355 \\
\hline $\begin{array}{l}\text { Kereskedelmi altiszt, szolga, } \\
\text { segéd }\end{array}$ & 11 & 16 & 20 & 17 & 9 & & 9 & 15 & 13 & 12 & & & & 122 \\
\hline Keresk. v. közlekedési munkás & & & & 4 & 5 & 13 & & 8 & & & & & & 30 \\
\hline Köztisztviselő & 44 & 53 & 36 & 37 & 48 & 55 & 55 & 50 & 50 & 58 & 45 & 207 & 112 & 850 \\
\hline Pap, tanár, tanító & 59 & 55 & 68 & 53 & 48 & 48 & 49 & 47 & 53 & 55 & 83 & 99 & 47 & 785 \\
\hline $\begin{array}{l}\text { Másféle értelmiségi (és ezek } \\
\text { írnokai) }\end{array}$ & 22 & 20 & 29 & 34 & 36 & 10 & 37 & 35 & 50 & 33 & & 72 & 31 & 409 \\
\hline Közhivatali altiszt, szolga & 8 & 7 & 3 & 9 & 11 & 4 & 8 & 12 & & 7 & 2 & & & 71 \\
\hline Katonatiszt & & 1 & 1 & 2 & 2 & & 2 & 1 & 4 & 2 & 1 & & & 16 \\
\hline Katonaaltiszt & 2 & 2 & 3 & 3 & 3 & 4 & 3 & 3 & 1 & 3 & 2 & & & 29 \\
\hline Nyugdíjas tisztviselő & 5 & 8 & 14 & 10 & 1 & & 21 & 19 & 16 & 18 & 14 & 32 & 18 & 176 \\
\hline Nyugdíjas altiszt & & & & & 9 & & 3 & 7 & 5 & 1 & & & & 25 \\
\hline Magánzó & 31 & 33 & 22 & 38 & 32 & 37 & 34 & 28 & 49 & 57 & 44 & 53 & 43 & 501 \\
\hline Egyéb és ismeretlen & 1 & 2 & 1 & 4 & 4 & 3 & 3 & 2 & 1 & & & & & 21 \\
\hline Napszámos & 28 & 16 & 12 & & 2 & 9 & 7 & 1 & & 2 & 8 & & & 85 \\
\hline Összesen: & 410 & 425 & 430 & 396 & 425 & 390 & 422 & 400 & 440 & 469 & 450 & 960 & 468 & 6039 \\
\hline
\end{tabular}


(1921-1930)

\begin{tabular}{|c|c|c|c|c|c|c|c|c|c|c|c|}
\hline & $\widetilde{\widetilde{\Omega}}$ & สิ & $\stackrel{\widetilde{\Omega}}{\Omega}$ & $\stackrel{\sim}{\Omega}$ & $\stackrel{\Omega}{\Omega}$ & $\stackrel{\text { న్ }}{2}$ & $\widehat{\widehat{\sigma}}$ & 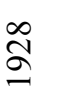 & ลે & $\stackrel{\curvearrowright}{2}$ & $\begin{array}{l}\tilde{N}^{2} \\
W_{0} \\
: 0\end{array}$ \\
\hline $\begin{array}{l}\text { Kisbirtokos, } \\
\text { földmüves }\end{array}$ & 53 & 54 & 45 & 18 & 16 & 21 & 21 & 13 & 15 & 16 & 272 \\
\hline Nagybirtokos & 3 & 5 & & 8 & 7 & 8 & 3 & & & & 44 \\
\hline $\begin{array}{l}\text { Nagybirtokos, } \\
\text { bérlö, } \\
\text { földmüves, } \\
\text { napszámos }\end{array}$ & 1 & & & & & & & & & & 1 \\
\hline Kisiparos & 3 & & & & & & & & & & 3 \\
\hline Gyáros & 87 & 75 & 65 & 40 & 36 & 30 & 32 & 18 & 21 & 33 & 437 \\
\hline Kiskereskedő & 8 & 7 & 7 & 6 & 5 & 2 & 1 & & & & 36 \\
\hline Nagy- & 52 & 42 & 34 & 20 & 10 & 8 & 7 & 5 & 3 & 6 & 187 \\
\hline kereskedő & 7 & 7 & 3 & & 1 & 2 & & & & & 20 \\
\hline Pap & 12 & 9 & 7 & 3 & 3 & 4 & 3 & 4 & 3 & 3 & 51 \\
\hline Tanító & 19 & 17 & 10 & 8 & 7 & 6 & 3 & 5 & 5 & 6 & 86 \\
\hline Tanár & 8 & 6 & 5 & 3 & 3 & 2 & & 1 & 1 & 2 & 31 \\
\hline Tisztviselö & 60 & 92 & 80 & 53 & 32 & 52 & 39 & 22 & 13 & 21 & 464 \\
\hline Nyugdíjas & 25 & 11 & 16 & 12 & 8 & 4 & & & 1 & 2 & 78 \\
\hline Egyéb értelmiségi & 56 & 31 & 24 & 10 & 11 & 8 & 16 & 4 & 4 & 6 & 169 \\
\hline Magánzó & 44 & 37 & 13 & 2 & 7 & 4 & 4 & 2 & 3 & & 116 \\
\hline Szolga & & & & & 5 & 2 & 6 & 8 & 13 & 11 & 45 \\
\hline Háztartásbeli & & & & & & 2 & 2 & & 2 & 1 & 7 \\
\hline Árva & & & & & & 19 & & & & & 19 \\
\hline Sszesen: & 438 & 403 & 309 & 183 & 151 & 155 & 156 & 82 & 84 & 106 & 2067 \\
\hline
\end{tabular}


(1941-1942)

\begin{tabular}{|c|c|c|c|}
\hline & 1941 & 1942 & Összesen \\
\hline Középbirtokos & 20 & 6 & 26 \\
\hline Kisbirtokos & 176 & 168 & 344 \\
\hline Napszámos & 3 & 18 & 21 \\
\hline Östermelő & 2 & 8 & 10 \\
\hline Gazdasági tisztviselö & 5 & 9 & 14 \\
\hline Földmüves, napszámos & 1 & & 1 \\
\hline Nagyiparos & & 1 & 1 \\
\hline Kisiparos & 94 & 98 & 192 \\
\hline Bányatisztviselö & 8 & 10 & 18 \\
\hline Ipari segédszemélyzet & 4 & & 4 \\
\hline Nagykereskedő & 2 & 7 & 9 \\
\hline Kiskereskedő & 32 & 26 & 58 \\
\hline Kereskedelmi tisztviselö & 5 & 5 & 10 \\
\hline Közlekedési kisvállalkozó & 6 & 34 & 40 \\
\hline Közlekedési tisztviselö & 23 & 23 & 46 \\
\hline Közlekedési alkalmazott & 28 & & 28 \\
\hline Napszámos & 1 & & 1 \\
\hline Köztisztviselő & 49 & 52 & 101 \\
\hline Pap, tanár, tanító & 60 & 47 & 107 \\
\hline Más értelmiségi & 19 & 21 & 40 \\
\hline Értelmiségi alkalmazott & 5 & & 5 \\
\hline Közhivatali alkalmazott & 9 & 13 & 22 \\
\hline Katona & 1 & 2 & 3 \\
\hline Katonaaltiszt & 7 & 4 & 11 \\
\hline Nyugdíjas tisztviselö & 21 & 13 & 34 \\
\hline Tökés, háztulajdonos & 2 & 1 & 3 \\
\hline Napszámos & 9 & & 9 \\
\hline Ismeretlen & 1 & 12 & 13 \\
\hline Árva & & 1 & 1 \\
\hline Összesen: & 595 & 580 & 1175 \\
\hline
\end{tabular}

Az adatok összegzéséböl kitünik, hogy e korszakban a diákság túlnyomórészt értelmiségi családokból származott; tisztviselö, tanár, tanító, pap és más értelmiségi család gyermeke 8327 tanuló (46,61\%). Ezt követően a legszámosabb réteg a kisbirtokos, azaz földmüves 3771 tanuló, 21,80\% - és a polgári - kisiparos, kiskereskedő - családból származó diákságé: 3488 tanuló, 19,52\%. Nagybirtokos, középbirtokos, nagykereskedő, nagyiparos, gyáros családból való 1071 diák (5,98\%); napszámos, szolga gyermeke 808 (4,52\%), munkásoké 322 (1,80\%). Egyéb foglalkozású családból származott, valamint árva 79 diák $(0,44 \%)$.

A tanulók felekezeti és nemzetiségi hovatartozásáról a 15-ös számú táblázat tájékoztat. 
15. számú táblázat A református gimnázium tanulóinak vallás szerinti megoszlása 1869-1944 között

\begin{tabular}{|c|c|c|c|c|c|c|c|c|}
\hline Év & 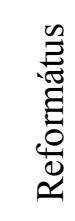 & 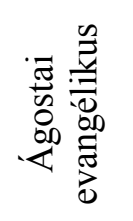 & 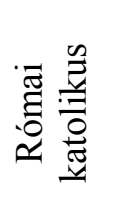 & 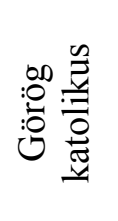 & 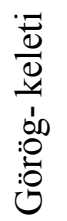 & . & 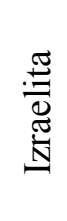 & $\begin{array}{l}\tilde{D} \\
\text { Dे } \\
\tilde{N} \\
0 \\
0\end{array}$ \\
\hline 1869 & & & & & & & & 157 \\
\hline 1870 & 173 & & 2 & 5 & & & 13 & 193 \\
\hline 1871 & & & & & & & & \\
\hline 1872 & 153 & & 7 & 12 & & & 21 & 193 \\
\hline 1873 & & & & & & & & \\
\hline 1874 & 125 & 1 & 5 & 17 & & & 17 & 165 \\
\hline 1875 & 146 & 1 & 6 & 15 & & & 21 & 197 \\
\hline 1876 & 137 & 1 & 3 & 12 & & & 24 & 194 \\
\hline 1877 & 133 & 1 & 14 & 13 & & & 14 & 185 \\
\hline 1878 & 144 & 1 & 13 & 12 & & & 28 & 198 \\
\hline 1879 & 155 & 1 & 5 & 9 & & & 23 & 193 \\
\hline 1880 & 159 & 2 & 6 & 8 & & & 15 & 190 \\
\hline 1881 & 146 & 1 & 9 & 2 & & & 16 & 175 \\
\hline 1882 & 159 & 1 & 7 & 2 & & & 18 & 190 \\
\hline 1883 & 149 & 1 & 13 & 8 & & & 29 & 200 \\
\hline 1884 & 145 & 3 & 8 & 11 & & & 33 & 200 \\
\hline 1885 & 140 & 2 & 11 & 9 & & & 23 & 185 \\
\hline 1886 & 143 & & 10 & 7 & & & 35 & 195 \\
\hline 1887 & 139 & & 7 & 10 & & & 25 & 181 \\
\hline 1888 & 136 & 3 & 12 & 6 & & & 33 & 190 \\
\hline 1889 & 143 & 3 & 11 & 8 & & & 32 & 197 \\
\hline 1890 & 165 & 7 & 13 & 16 & & & 42 & 243 \\
\hline 1891 & 181 & 12 & 12 & 10 & & & 61 & 276 \\
\hline 1892 & 168 & 8 & 14 & 5 & & & 53 & 248 \\
\hline 1893 & 177 & 6 & 14 & 5 & & & 51 & 253 \\
\hline 1894 & 188 & 7 & 17 & 8 & & & 39 & 252 \\
\hline 1895 & 191 & 7 & 10 & 9 & & & 57 & 281 \\
\hline 1896 & 187 & 11 & 13 & 7 & 1 & & 59 & 278 \\
\hline 1897 & 210 & 12 & 15 & 6 & & & 50 & 293 \\
\hline 1898 & 222 & 11 & 10 & 8 & & & 47 & 298 \\
\hline 1899 & 221 & 5 & 10 & 9 & & & 53 & 298 \\
\hline
\end{tabular}




\begin{tabular}{|c|c|c|c|c|c|c|c|c|}
\hline Év & 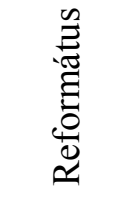 & 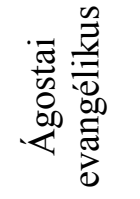 & 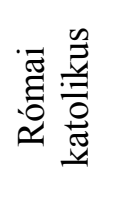 & 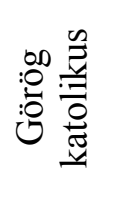 & مُ & & 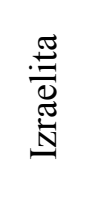 & $\begin{array}{l}\text { Dี } \\
\mathbb{N} \\
\tilde{N} \\
: 0 \\
: 0\end{array}$ \\
\hline 1900 & 222 & 9 & 11 & 3 & 1 & & 54 & 300 \\
\hline 1901 & 219 & 9 & 9 & 4 & & & 51 & 292 \\
\hline 1902 & 246 & 6 & 7 & 4 & & & 69 & 332 \\
\hline 1903 & 261 & 6 & 10 & 4 & & & 85 & 366 \\
\hline 1904 & 288 & 5 & 13 & 10 & 1 & & 73 & 390 \\
\hline 1905 & 323 & 7 & 15 & 9 & & & 70 & 424 \\
\hline 1906 & 331 & 9 & 18 & 8 & & & 50 & 416 \\
\hline 1907 & 329 & 4 & 23 & 9 & & & 40 & 405 \\
\hline 1908 & 333 & 3 & 16 & 12 & & 1 & 45 & 410 \\
\hline 1909 & 340 & 6 & 17 & 9 & & 1 & 42 & 415 \\
\hline 1910 & 343 & 5 & 14 & 14 & 1 & 1 & 52 & 430 \\
\hline 1911 & 315 & 11 & 16 & 12 & 2 & & 52 & 410 \\
\hline 1912 & 316 & 10 & 18 & 14 & & & 60 & 418 \\
\hline 1913 & 324 & 8 & 22 & 18 & 1 & & 68 & 441 \\
\hline 1914 & 305 & 12 & 25 & 9 & 1 & & 69 & 421 \\
\hline 1915 & 292 & 9 & 18 & 7 & & 1 & 73 & 400 \\
\hline 1916 & 314 & 9 & 20 & 7 & & & 97 & 447 \\
\hline 1917 & 329 & 10 & 21 & 8 & & & 102 & 470 \\
\hline 1918 & 312 & 2 & 16 & 7 & & & 113 & 450 \\
\hline 1919 & 354 & 3 & 312 & 41 & & & 209 & 923 \\
\hline lány & 17 & & 2 & & & & 18 & 37 \\
\hline 1920 & 270 & 6 & 21 & 12 & & & 134 & 443 \\
\hline lány & 13 & & 2 & & & & 10 & 25 \\
\hline 1921 & 272 & 7 & 14 & 9 & & 1 & 135 & 438 \\
\hline 1922 & 274 & 7 & 4 & 4 & & & 114 & 403 \\
\hline 1923 & 218 & 7 & 5 & 2 & & & 77 & 312 \\
\hline 1924 & 128 & 3 & 8 & & & & 44 & 183 \\
\hline 1925 & 105 & 3 & 22 & & & & 21 & 151 \\
\hline 1926 & 94 & 3 & 53 & & & & 6 & 156 \\
\hline 1927 & 107 & 6 & 46 & & & & 3 & 162 \\
\hline 1928 & 54 & 2 & 28 & & & & & 84 \\
\hline 1929 & 66 & 2 & 17 & & & & & 85 \\
\hline 1930 & 82 & 4 & 20 & & & & & 106 \\
\hline 1941 & 531 & 9 & 21 & 3 & & 1 & 24 & 588 \\
\hline 1942 & 541 & 9 & 13 & 3 & 1 & 1 & 19 & 587 \\
\hline sszesen: & 13532 & 324 & 945 & 495 & & & 2228 & 18594 \\
\hline
\end{tabular}


A református gimnázium tanulóinak anyanyelvés nyelvismeret szerinti megoszlása

1869-1944 között

\section{(a 15. sz. táblázat folytatása)}

Év Magyar Németül Német Németül Román Ruténül $\begin{gathered}\text { Horvát- } \\
\text { szerbül }\end{gathered} \quad$ Olaszul Angolul \begin{tabular}{c}
$\begin{array}{c}\text { Fran- } \\
\text { ciául }\end{array}$ \\
\hline
\end{tabular}

1869

1870

1871

1872

1873

$1874 \quad 165$

$1875 \quad 189$

$\begin{array}{lll}1876 & 142 & 31\end{array}$

$\begin{array}{lll}1877 & 154 & 11\end{array}$

$\begin{array}{lll}1878 & 173 & 14\end{array}$

$\begin{array}{lll}1879 & 157 & 27\end{array}$

$\begin{array}{lll}1880 & 148 & 15\end{array}$

$\begin{array}{lll}1881 & 166 & 9\end{array}$

$\begin{array}{lll}1882 & 145 & 15\end{array}$

$\begin{array}{lll}1883 & 165 & 22\end{array}$

$\begin{array}{lll}1884 & 175 & 13\end{array}$

$\begin{array}{lll}1885 & 169 & 7\end{array}$

$\begin{array}{lll}1886 & 183 & 7\end{array}$

$\begin{array}{lll}1887 & 149 & 18\end{array}$

$\begin{array}{lll}1888 & 172 & 13\end{array}$

$\begin{array}{lll}1889 & 175 & 18\end{array}$

$\begin{array}{lll}1890 & 213 & 19\end{array}$

$\begin{array}{lll}1891 & 209 & 3\end{array}$

$\begin{array}{lll}1892 & 244 & 1\end{array}$

$1893 \quad 250$

$1894 \quad 249$

$1895 \quad 277$

$1896 \quad 276$

$1897 \quad 291$

$1898 \quad 298$

$1899 \quad 298$

$1900 \quad 300$

$1901 \quad 292$

$1902 \quad 332$

$1903 \quad 366$

$1904 \quad 389$

$1905 \quad 423$

$1906 \quad 416$

$1907 \quad 405$

$1908 \quad 391$

$1909 \quad 414$

$\begin{array}{rrr}3 & & 4 \\ 4 & & 4 \\ 13 & 5 \\ 16 & \\ 8 & 2 \\ 6 & \\ 7 & \\ 1 & \\ 7 & \\ 8 & \\ 11 & \\ 5 & \\ 5 & \\ 11 & \\ 3 & \\ 4 & \\ 11 & \\ 3 & \\ 3 & \\ 2 & \\ 3 & \\ 3 & \end{array}$

1
1

4

2

1

1

$$
1
$$

$$
\text { (1) }
$$

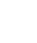

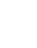

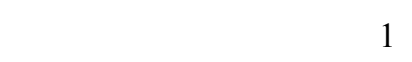

1

1

2

1

1 


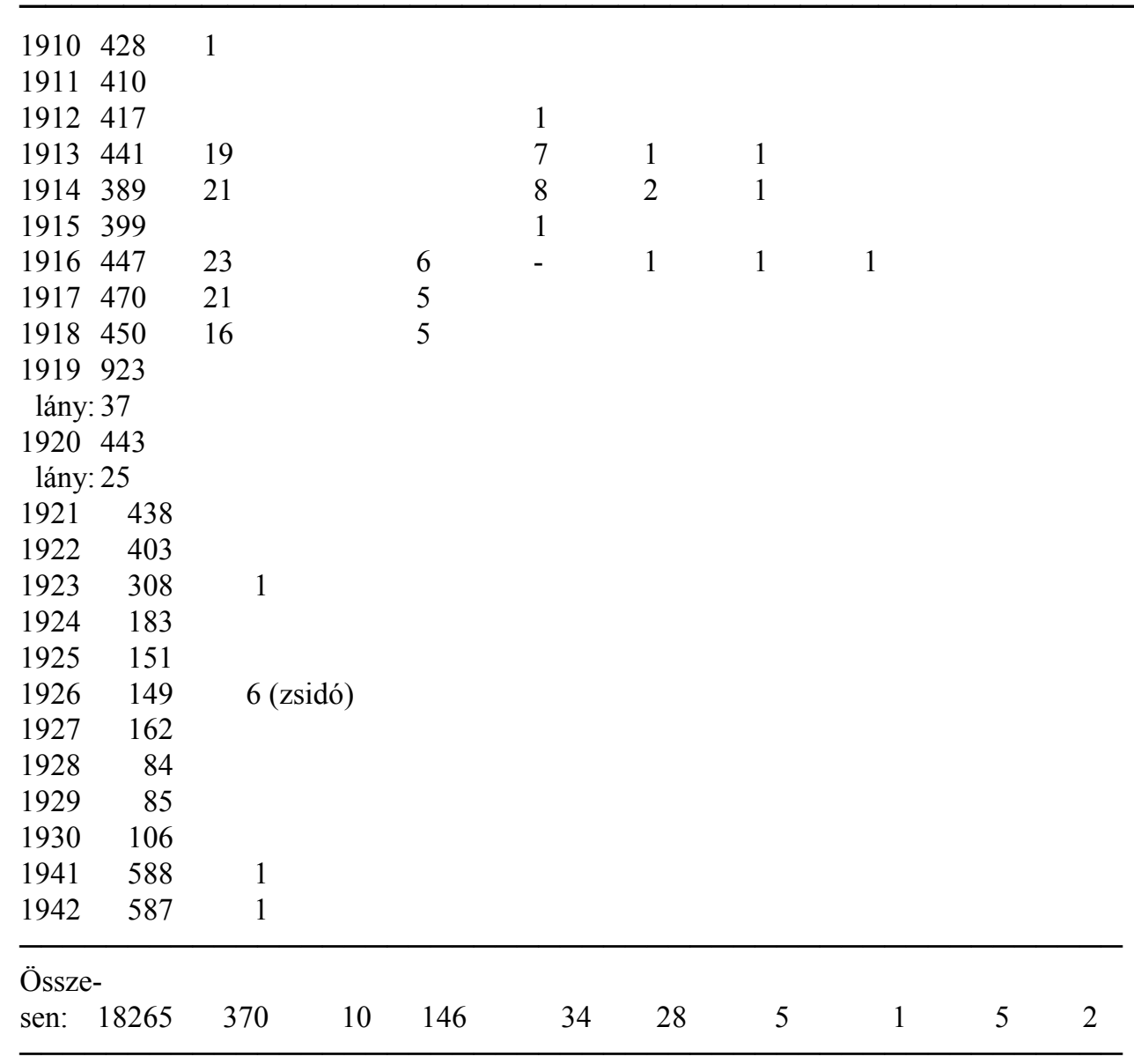

Az értesítők azt tanúsítják, hogy a később Szatmári Református Főgimnáziumnak nevezett kollégiumban nemcsak református vallású diákok jártak, tanultak. 1869-től a gimnáziumban tanult közel három és félszáz más protestáns (324 evangélikus, 7 unitárius), majdnem másfélezer katolikus (945 római katolikus, 495 görög katolikus), 2228 izraelita és néhány (9) görögkeleti vallású diák.

E tanulók túlnyomó többsége magyar anyanyelvü, magyar nemzetiségü volt. Az évkönyvek konkrétan csak 52 tanulóról közlik, hogy más nemzetiségü, köztük román, német, zsidó, szlovák származásúak. Minden bizonnyal azonban a "nyelvismeretről" készített statisztika idegen nyelvek ismeretét jelölő rovatában közölt adatok egy része nemzetiséget takar. Joggal feltételezhető, hogy a 146 németül és románul is, a 28 ruténül is tudó tanuló közül legtöbb román, illetőleg rutén családból származott, s feltételezhetően a németül beszélők között is voltak német, illetőleg sváb származású diákok. 


\section{Utószó}

A szatmárnémeti református kollégium történetéről szóló tanulmány megjelenését több mint két évtizedes munka s a már megírt kézirat évtizedes hányódása előzte meg.

A munka megírásának gondolatát (néhai) Dankanits Ádám történész barátom sugallta. A Hét munkatársaként 1972-ben olvasótalálkozón járt Szatmárnémetiben, tőle szereztem tudomást a matrikula létezéséről (és lelőhelyéröl). Meg kellene írni - mondta - a matrikula alapján az iskola történetét, ahogyan Jakó Zsigmond és Juhász István megírta az enyedi diákokét a nagyenyedi diáknévsorok alapján.

Az adatgyüjtés- és feldolgozás elveit, a követendő módszereket Jakó Zsigmond professzor úr körvonalazta számomra (mindezért s a munkavégzés folyamán kapott mindig hasznos segítségéért ezúton is köszönetet mondok), aztán munkához láttam.

A latin nyelvü matrikula lemásolása, a sokféle kézírás, gyakran csak nagyítóval kiolvasható bejegyzés pontos, betühü leírása, a rövidítések feloldása, a szövegek megfejtése, értelmezése magától értetődően igen sok időt igényelt.

Minthogy a kéziratos könyvet az idő (és hányattatása) megviselte, a szöveg elsődleges rögzítése (a leírás és a fényképmásolat elkészítése) után a matrikulát az egyetemi könyvtár szakembere szakszerüen restaurálta. Ennek során szétválasztotta a matrikula több összeragasztott lapját is. (Minden esetben téves bejegyzések, elrontott szövegek kerültek elö; közülük többet a feldolgozásban hasznosíthattam; két összeragasztott lap pedig XVII. századi latin képverset rejtett.)

Mindjárt munkám kezdetén Jakó Zsigmond professzor úr figyelmeztetett: a szakszerü történeti forráskutatás a hivatkozott dokumentumok ellenőrzött ismeretét, hü idézésüket követeli meg. A szatmárnémeti református kollégium XVII-XVIII. századi matrikulája esetében ez mindenekelött azt kívánta meg, hogy szakemberek ellenőrizzék latin szövegmásolataim pontosságát, hitelességét. Az első ellenőrzést a bukaresti Nicolae Iorga Történeti Intézet kutatója, Vekov Károly végezte el 1973-ban. Együttesen olvastuk el a teljes latin nyelvű szöveget, egyeztettük az én olvasatommal, megvizsgáltuk a feloldott rövidítéseket.

A latin szövegek másodszori ellenőrzését a kéziratnak a Kriterion Könyvkiadóhoz való benyújtása előtt Kiss András kolozsvári levéltáros végezte el. (Mindkettőjük fáradságos munkáját ezúton is megköszönöm!)

A matrikula történetéhez, féltő óvásához az is hozzátartozik, hogy semmiképp sem akartuk a figyelmet ráterelni, így a róla közölt (egyetlen) fénykép (Jakó Zsigmond: Írás, könyv, értelmiség) alá sem írtuk oda a lelöhelyét.

Mindenképpen utalnom kell a forráskutatásban megtapasztalt tényre: elödeink bizony nem mindig voltak pontosak a források felhasználása, idézése során; következésképp nem helytálló adatok, utalások is napvilágot láttak. Mindezekből pedig (természetszerüleg) nem valóságos állítások, következtetések (is) születtek.

A matrikulát - több mint három és fél évszázados megléte során többen is forgatták, hivatkoztak rá. Pontatlanul idézett számadatok, hibásan, elferdítetten közölt nevek tanúsítják: nem mindig hozzáértően jártak el. 
Egyik példája ennek az, amit az 1672-es batizvasvári csatában részt vett és elesett szatmári diákokról a század elején megírtak. A mai batizi temetőben áll az a hatalmas obeliszk, amelyet a Szatmárnémeti Református Főgimnázium diákjai állítottak (1914-ben) a batizvasvári csatában a kurucok oldalán harcoló, elesett, a tömegsírba eltemetett egykori kollégiumi diákok emlékére.

Erröl a XX. század elején feltárt tömegsírról azt írta Ferenczi János (újságíró, helytörténeti munka szerzője), hogy a sok száz halott közt található a kollégium e csatában elesett 49 diákja is. Név szerint fel is sorolja öket. Közlése - nem tudni, milyen forrásra alapozta - már csak azért sem lehet hiteles, mert a felsoroltakból 25 diák a csatát követő években is a kollégiumban tanult, évenként aláírta az ún. aláírási jegyzőkönyveket.

A kutatómunka során azt is megtapasztaltam, hogy egy-egy régi (egykorú), nyomtatott forrásban (is) megjelent állítás is lehet téves. A debreceni kollégium történetével foglalkozó munka (valószínűleg) meghaltnak nyilvánít olyan tanítót, aki „eltünése” után adataink szerint Szatmáron tanított.

A második alapforrás, a XIX. századi anyakönyv teljesen magyar nyelvü, mindvégig szép, olvasható kézírással vezetett munka, olvasata semmilyen gondot nem okozott.

A tanulmány utolsó fejezetében kitekintek az 1852-es évet követő időszakra is, e korszak sok számadatát idézem (táblázatokba foglaltam), forrásaim a gimnázium nyomtatásban megjelent évkönyvei. Az évkönyvek java része megtalálható a kolozsvári Egyetemi Könyvtárban, illetőleg a marosvásárhelyi Teleki Téka dokumentációs részlegén. A hiányzók adatait a budapesti Országos Széchényi Könyvtárból tanulmányoztam.

Az elkészült munkát Szatmári diákok 1610-1852 címen 1983-ban benyújtottam a Kriterion Könyvkiadóhoz, de - mint ismeretes - tárgya miatt (magyar müvelödéstörténet) nem jelenhetett meg, a mintegy 30 letiltott könyv közé került.

Közben azt javasolta Jakó Zsigmond professzor úr, hogy fel kellene kutatni és meg kellene írni a (szintén XVII. századi) Pázmány Péter alapította katolikus kollégium anyagát/történetét is.

Kevés reménnyel láthattam munkához, mert a jogutód iskolában (valamikor az államosítás utáni években) kidobták a régi irattári anyagokat. Nem várt felfedezés eredményeképp igen jelentős irattári anyagra bukkantam, s ebböl az derül ki, hogy a Pázmány alapította kollégium mellett a XIX. század elején még egy, az akkori középiskolára épülö, ennél magasabb fokú intézmény, az ún. Püspöki Líceum is müködött Szatmárnémetiben.

A Szatmári diákok 1610-1852 címü munka így kétkötetessé vált. Természetesen ezt már nem adtam oda a Kriterion Könyvkiadónak. A könyv megjelenésének egyetlen lehetséges módjává a külföldi kiadása vált. Ez azonban (elsősorban a már fentebb említett okból) egyelőre nem volt lehetséges.

Mindkét kötet tartalmazta a szatmári iskolák könyvtárának anyagát is, ezek leltárát, gyarapodási módját; előkerült ugyanis a szatmári jezsuita rendi kolostor és a pálos rendiek könyvtárjegyzéke is.

A szegedi József Attila Tudományegyetem I. sz. Magyar Irodalomtörténeti Tanszékén müködő könyvtártörténeti kutatócsoport munkaközössége (Keserü Bálint professzor szerkesztésében) Adattár XVI-XVIII. századi szellemi mozgalmaink történetéhez címen megjelenő sorozatának 14. kötete a Partiuni könyvesházak 1623-1730. Ebben a kötetben közöltem a munkámból ide illeszthetö részt 1988-ban Szatmár - A református kollégium könyvtára 1632- 
1727 címmel. Terjedelme 45 lapnyi; természetesen álnéven (Kulcsár György) vállalkozhattam az akkori közlésére.

Elérkezett végül a könyv megjelentethetőségének az ideje, kiadására a JATE régi magyar irodalmi tanszéke vállalkozott.

Minthogy a munkát (az adattár könnyebb hasznosítása céljából) diáknévmutatókkal kellett ellátni, s ezek elkészítése időigényes volt, a megjelentetésben időbeli csúszást okozott.

Változtatni kellett azonban magán a munkán is, mivel az a Fontes Rerum Scholasticarum sorozatba került. Konkrétan: a tanulmányi részeket ki kellett iktatni; ezt rövid bevezetök (mindegyik iskola elött) helyettesítik.

A Szatmári diákok 1610-1852 (Szeged 1994) ilyenformán mindhárom iskola dokumentumanyagát tartalmazza, amelyből azonban kimaradtak a könyvtárak. A tanulmányi rész pedig két külön kiadványban jelenik meg. Az egyikben (itt) a református kollégium, a másikban a katolikus iskolák anyagának a feldolgozása. (Sajnos mindegyikből kimaradt a képanyag.)

Habent sua fata libelli - tartja a régi latin közmondás. Romániai magyar tudományosságunk viszontagságos történetéhez e munka kiadástörténete is beszédes adalék.

Szatmárnémeti, 1994. július 15. 